\title{
Icoonprojecten waterkwaliteit
}

Bouwstenen voor icoonprojecten in overige wateren

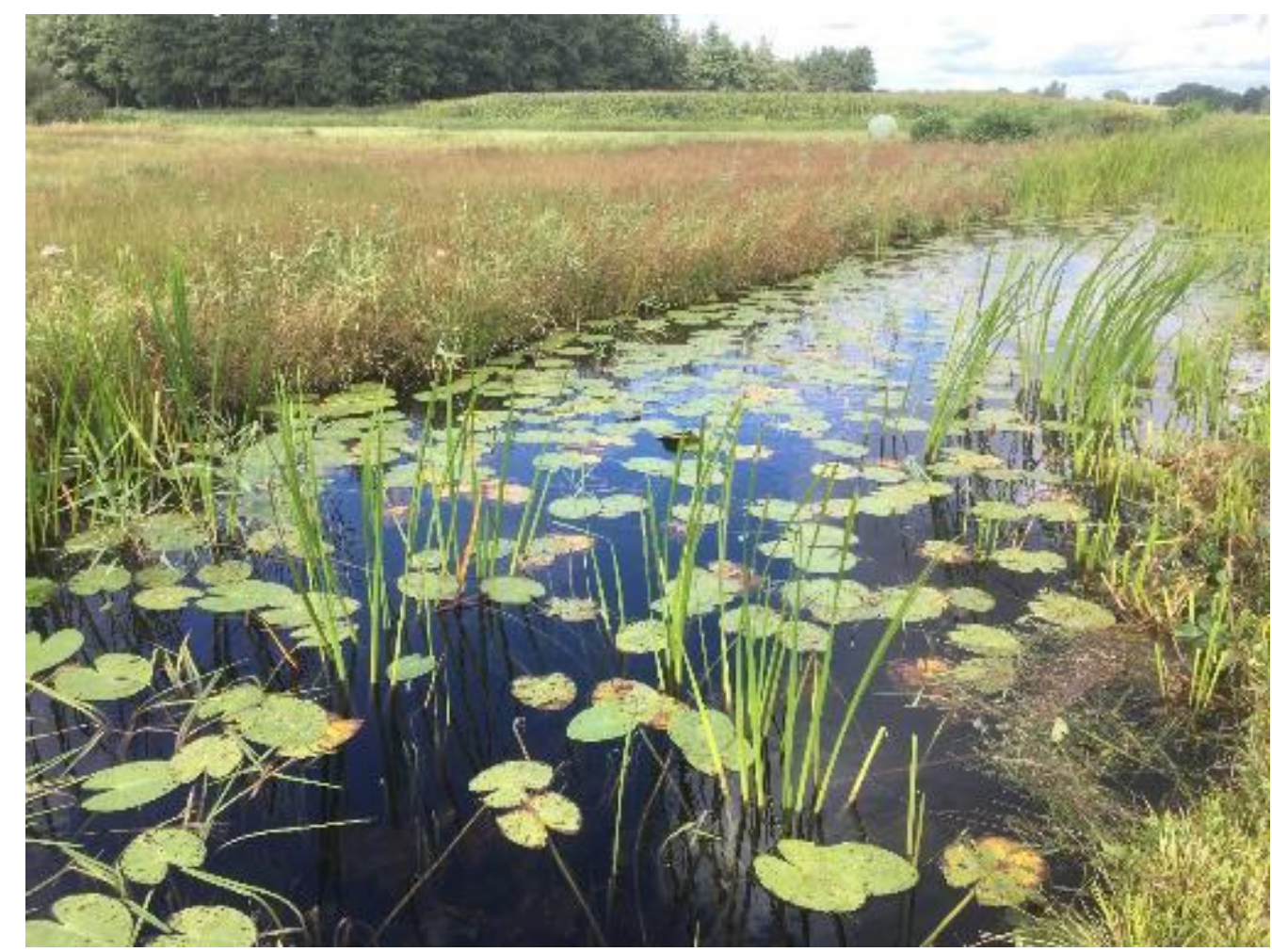

Ralf Verdonschot, Piet Verdonschot

Zoetwaterecosystemen, Wageningen Environmental Research

Maart 2019

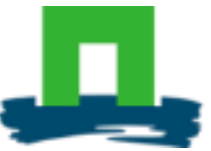




\section{Auteurs}

Ralf Verdonschot, Piet Verdonschot (correspondentie: ralf.verdonschot@wur.nl)

\section{Opdrachtgever}

Natuur en Milieu, contactpersoon Kawire Gosselink.

\section{Projectgroep}

Kawire Gosselink, Karen Eilers

\section{Wijze van citeren}

Verdonschot R.C.M., Verdonschot P.F.M. (2019) Icoonprojecten waterkwaliteit. Bouwstenen voor icoonprojecten in overige wateren. Notitie Zoetwaterecosystemen, Wageningen Environmental Research, Wageningen UR, Wageningen.

\section{Trefwoorden}

herstelmaatregelen, monitoring, systeemanalyse, knelpuntenanalyse, scenario-analyse

\section{Beeldmateriaal}

Foto voorzijde: sloot in de Wieden (Ralf Verdonschot)

ISBN: 978-94-6343-898-8

DOI: https://doi.org/10.18174/472010

Dit project is uitgevoerd in opdracht van Natuur \& Milieu

(C) 2019 Zoetwaterecosystemen, Wageningen Environmental Research

- Overname, verveelvoudiging of openbaarmaking van deze uitgave is toegestaan mits met duidelijke bronvermelding.

- Overname, verveelvoudiging of openbaarmaking is niet toegestaan voor commerciële doeleinden en/of geldelijk gewin.

- Overname, verveelvoudiging of openbaarmaking is niet toegestaan voor die gedeelten van deze uitgave waarvan duidelijk is dat de auteursrechten liggen bij derden en/of zijn voorbehouden.

Wageningen Environmental Research aanvaardt geen aansprakelijkheid voor eventuele schade voortvloeiend uit het gebruik van de resultaten van dit onderzoek of de toepassing van de adviezen. 


\section{Inhoud}

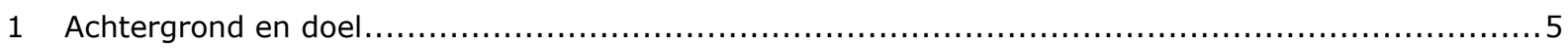

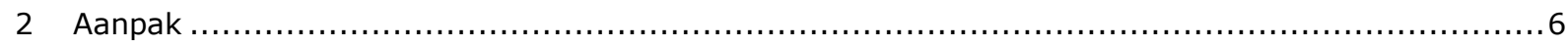

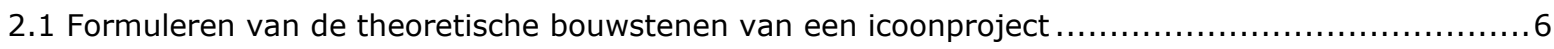

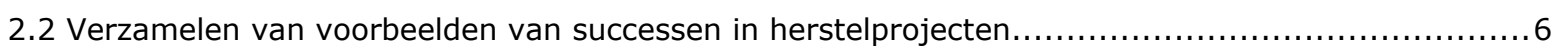

2.3 Samenbrengen van de theoretische bouwstenen en de informatie uit de projecten $\ldots \ldots \ldots \ldots \ldots \ldots \ldots$

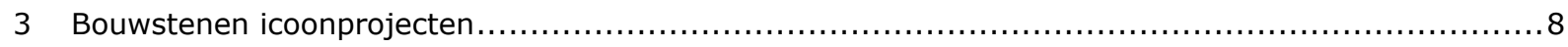

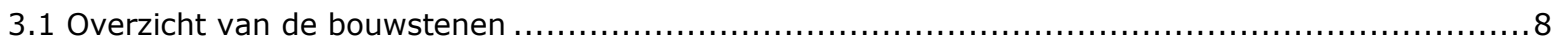

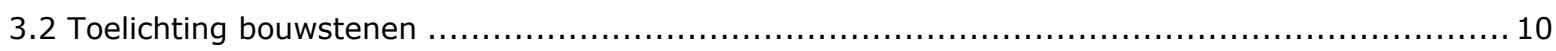

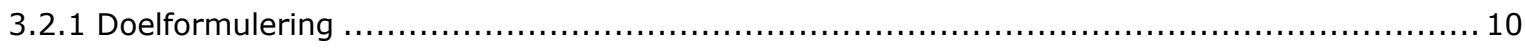

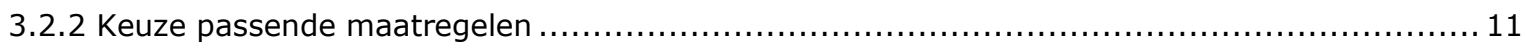

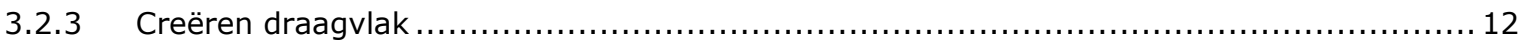

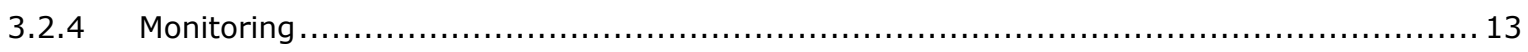

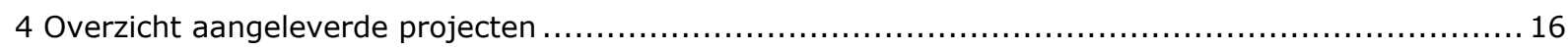

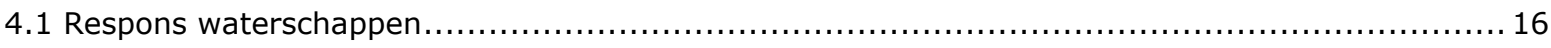

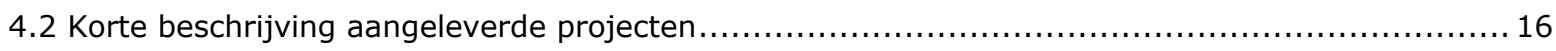

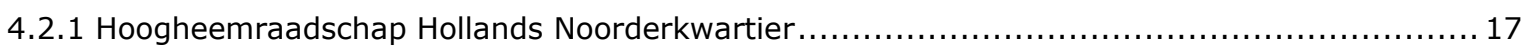

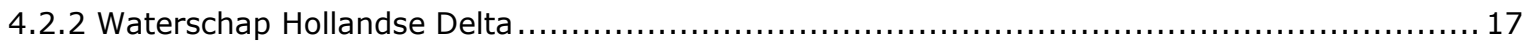

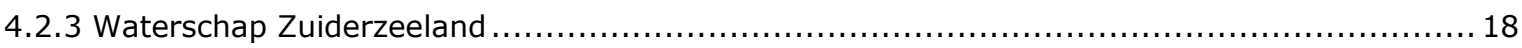

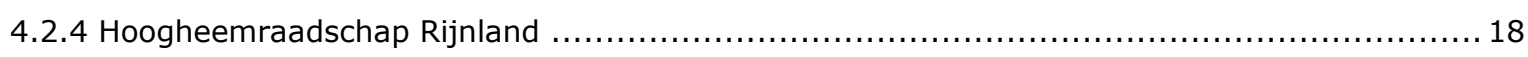

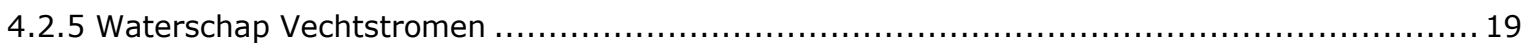

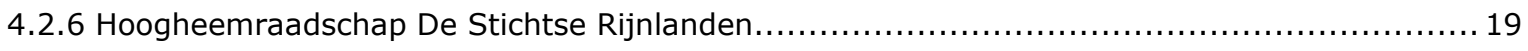

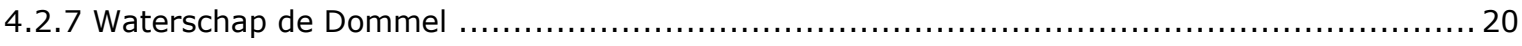

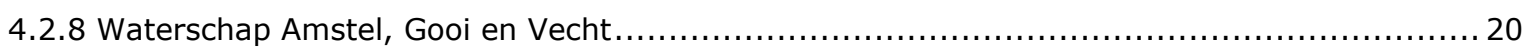

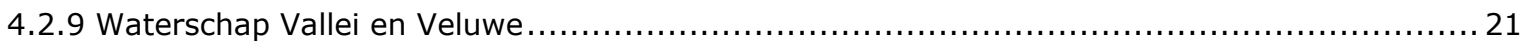

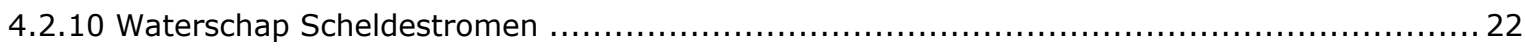

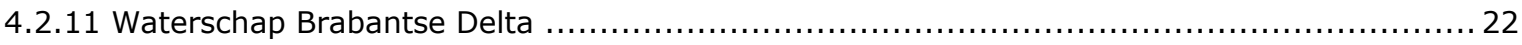

5 Vergelijking tussen aangeleverde projecten en de blauwdruk voor een icoonproject ...................24

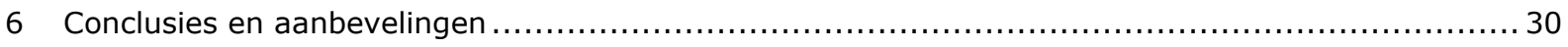

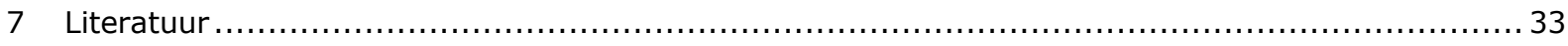

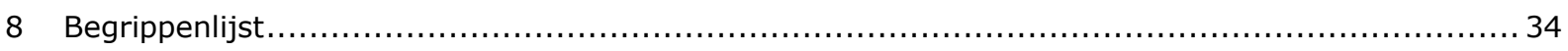

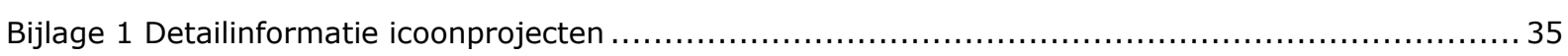

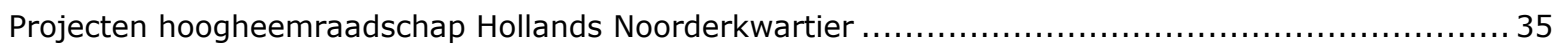

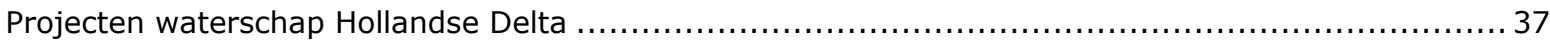

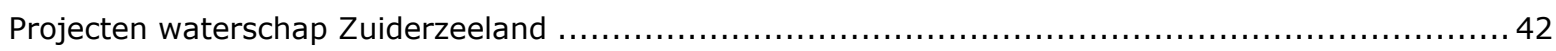




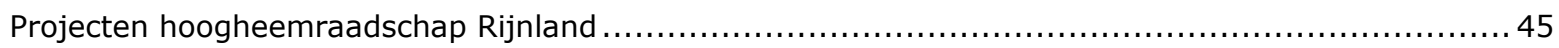

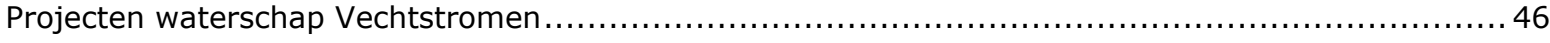

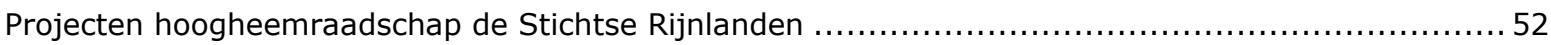

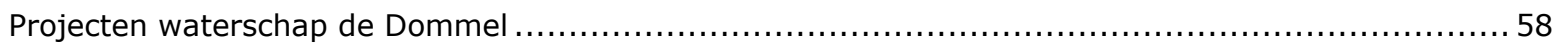

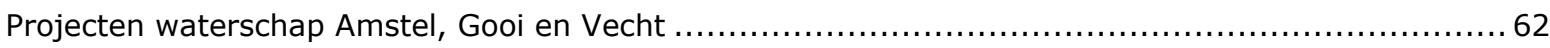

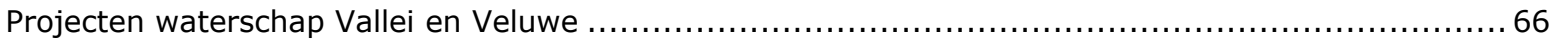

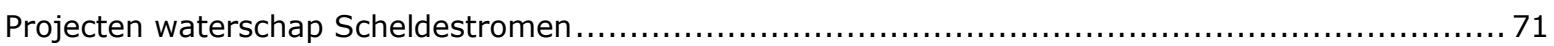

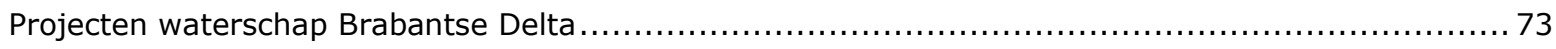

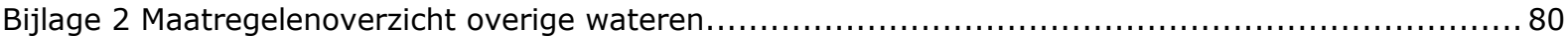

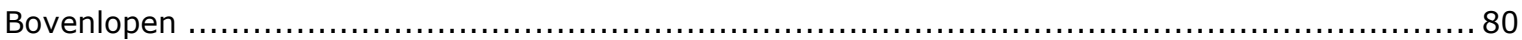

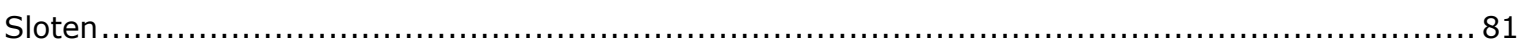

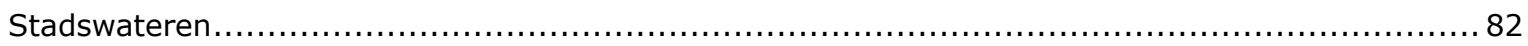




\section{Achtergrond en doel}

Natuur \& Milieu gaat aan de slag om de waterkwaliteit in overige wateren een positieve stimulans te geven. In veel van deze wateren voldoet de kwaliteit namelijk nog niet aan de eisen die vanuit de KaderRichtlijn Water (KRW) aan waterlichamen gesteld wordt. Hiervoor heeft ze Wageningen Environmental Research (WEnR) gevraagd bouwstenen van succesvolle projecten te verzamelen bij de Nederlandse waterschappen, hiervan een overzicht te maken en deze aan de hand van theoretische kennis van herstelecologie te evalueren en te combineren tot een blauwdruk voor 'icoon'-projecten in een selectie van de overige wateren. De selectie bestaat uit de bovenlopen van beken, sloten en stadswateren. 


\section{Aanpak}

Deze rapportage bestaat uit drie onderdelen: het definiëren van de bouwstenen van een icoonproject (theoretische blauwdruk), een inventarisatie van voorbeeldprojecten bij de waterschappen en het samenbrengen van de theoretische bouwstenen en de informatie uit de voorbeeldprojecten.

\subsection{Formuleren van de theoretische bouwstenen van een icoonproject}

Met ervaringen uit herstelprojecten in binnen- en buitenland en de theorieën over herstel van aquatische systemen als uitgangspunt (o.a. Verdonschot, 1995; Feld et al., 2011; Peeters et al., 2014) zijn de bouwstenen van een theoretisch icoonproject opgesteld. Dit icoonproject heeft als doel de ecologische waterkwaliteit te verbeteren, dit wil zeggen een goede biologische toestand (levensgemeenschappen) met de bijbehorende hydrologische, morfologische en fysisch-chemische randvoorwaarden. Iedere bouwsteen wordt toegelicht en er worden voorbeelden gegeven uit de praktijk.

\subsection{Verzamelen van voorbeelden van successen in herstelprojecten}

Er is contact opgenomen met adviseurs waterkwaliteit/ecologie en beleidsmakers van de 21 Nederlandse waterschappen om te vragen naar hun succesvolle projecten of andere goede voorbeelden die de afgelopen jaren zijn uitgevoerd om de (ecologische) waterkwaliteit te verbeteren (Tabel 2.1). Er zijn vijf vragen gesteld, om de onderlinge vergelijking tussen de projecten te kunnen vereenvoudigen:

1. Setting. Om wat voor type waterlichaam/systeem gaat het?

2. Doel. Waarom wordt dit waterlichaam hersteld of het project uitgevoerd (belangrijkste knelpunten)?

3. Streefbeeld. Wat is de stip aan de horizon?

4. Aanpak en tijdslijn. Wat is er gedaan en wanneer?

5. Resultaten. Wat zijn de belangrijkste resultaten tot nu toe (biologische, hydrologische, morfologische, fysisch-chemische parameters of overige (landschapsbeleving e.d.) en hoe is dit vastgesteld?

De ingewonnen informatie is gebundeld in korte beschrijvingen. Deze serie beschrijvingen vormt een doorsnede van de projecten bij de Nederlandse waterschappen die als doel hebben de waterkwaliteit te verbeteren.

\subsection{Samenbrengen van de theoretische bouwstenen en de informatie uit de projecten}

De volgende stap bestond uit het vergelijken van de onderdelen waaruit de aangeleverde projecten bestaan met de bouwstenen waaruit een icoonproject is opgebouwd. Hiermee wordt inzichtelijk gemaakt waar op dit moment het zwaartepunt ligt binnen de herstelstrategieën van de waterschappen en welke onderdelen minder aandacht krijgen. Op de verschillen en overeenkomsten wordt vervolgens dieper ingegaan. 
Tabel 2.1: Overzicht waterschappen en betrokken medewerkers. *: heeft voorbeeldprojecten aangeleverd.

\begin{tabular}{|c|c|c|}
\hline Waterschap & Contact ecologie & Contact beleid \\
\hline Waterschap Noorderzijlvest & Edwin van der Pouw Kraan & Melissa van Hoorn \\
\hline Wetterskip Fryslân & Harry Boonstra & Koos Koops \\
\hline Waterschap Hunze en Aa's & Peter-Paul Schollema & Hermen Klomp \\
\hline Waterschap Drents Overijsselse Delta & Petra Schep & Bert Moonen \\
\hline Waterschap Vechtstromen* & Gertie Schmidt & Maarten Zonderwijk \\
\hline Waterschap Vallei en Veluwe* & Peter van Beers & Maarten Veldhuis \\
\hline Waterschap Rijn en IJssel & John Lenssen & Michiel Schaap \\
\hline Hoogheemraadschap De Stichtse Rijnlanden* & Nikki Dijkstra & Peter Heuts \\
\hline Waterschap Amstel, Gooi en Vecht* & Tim Pelsma & Gerard ter Heerdt \\
\hline Hoogheemraadschap Hollands Noorderkwartier* & Sandra Roodzand & Gert van Ee \\
\hline Hoogheemraadschap van Rijnland* & Lucienne Vuister & Bart Schaub \\
\hline Hoogheemraadschap van Delfland & Helen Hangelbroek & Ronald Bakkum \\
\hline $\begin{array}{l}\text { Hoogheemraadschap van Schieland en de } \\
\text { Krimpenerwaard }\end{array}$ & Johan van Tent & Jack Hemelraad \\
\hline Waterschap Rivierenland & Ronald Gylstra & Erik Riemersma \\
\hline Waterschap Hollandse Delta* & Fred Kuipers & Hanneke Maandag \\
\hline Waterschap Scheldestromen* & Yvonne van Scheppingen & Marius van Wingerden \\
\hline Waterschap Brabantse Delta* & Marco Beers & Guido Waajen \\
\hline Waterschap De Dommel* & Ineke Barten & Jan van de Graaf \\
\hline Waterschap Aa en Maas & Rob Fraaije & Carlo Rutjes \\
\hline Waterschap Limburg & Esther de Jong & Frans Verdonschot \\
\hline Waterschap Zuiderzeeland* & Martijn Hokken & Harry Bouwhuis \\
\hline
\end{tabular}




\section{Bouwstenen icoonprojecten}

\subsection{Overzicht van de bouwstenen}

Met ervaringen uit herstelprojecten in binnen- en buitenland en de recente theorieën over herstel van aquatische systemen als uitgangspunt zijn de bouwstenen van een theoretisch icoonproject, dat als doel heeft de waterkwaliteit te verbeteren, opgesteld (Tabel 3.1). Er is onderscheid gemaakt in vier fasen gedurende de looptijd van een project: doelformulering, keuze passende maatregelen, creëren van draagvlak voor deze keuze en tenslotte monitoring voor, tijdens en na uitvoering van de maatregelen. Elke bouwsteen wordt verder toegelicht in de volgende paragrafen. Sommige onderdelen zouden binnen meerdere bouwstenen geplaatst kunnen worden, maar zijn bij de naar onze mening best passende bouwsteen ondergebracht.

Tabel 3.1: Bouwstenen van een theoretisch icoonproject.

\begin{tabular}{|c|c|c|c|}
\hline Fase & Bouwsteen & $\begin{array}{l}\text { Waarom } \\
\text { belangrijk? }\end{array}$ & $\begin{array}{l}\text { Onderdelen binnen deze } \\
\text { bouwsteen }\end{array}$ \\
\hline \multirow[t]{2}{*}{$\begin{array}{l}\text { 1. Doelformulering } \\
\text { project }\end{array}$} & $\begin{array}{l}\text { a. } \\
\text { Systeemanalyse }\end{array}$ & $\begin{array}{l}\text { De basis van een } \\
\text { project is het } \\
\text { begrijpen van het } \\
\text { systeem. }\end{array}$ & $\begin{array}{l}\text { - Het ontdekken van de } \\
\text { stuurfactoren in het systeem } \\
\text { vormt de basis voor het } \\
\text { herkennen van knelpunten en het } \\
\text { nemen van maatregelen. }\end{array}$ \\
\hline & $\begin{array}{l}\text { b. Knelpunten- } \\
\text { identificatie }\end{array}$ & $\begin{array}{l}\text { Knelpunten zorgen } \\
\text { ervoor dat de } \\
\text { huidige toestand } \\
\text { niet overeenkomt } \\
\text { met de gewenste } \\
\text { toestand. Deze } \\
\text { moeten worden } \\
\text { aangepakt in het } \\
\text { project. }\end{array}$ & $\begin{array}{l}\text { - Vergelijking beleidsdoel } \\
\text { (bijvoorbeeld KRW) en huidige } \\
\text { toestand. } \\
\text { Diagnose op basis } \\
\text { watersysteemanalyse als basis } \\
\text { doelformulering project. } \\
\text { - Projectdoel wordt in concrete } \\
\text { gekwantificeerde termen } \\
\text { opgesteld. }\end{array}$ \\
\hline \multirow[t]{2}{*}{$\begin{array}{l}\text { 2. Keuze passende } \\
\text { maatregelen }\end{array}$} & a. Effectiviteit & $\begin{array}{l}\text { Voor een optimaal } \\
\text { resultaat moeten } \\
\text { maatregelen } \\
\text { passen op de } \\
\text { knelpunten en } \\
\text { leiden tot het } \\
\text { projectdoel met } \\
\text { een zo laag } \\
\text { mogelijke } \\
\text { inspanning/kosten. }\end{array}$ & $\begin{array}{l}\text { - Hoge slagingskans (direct of } \\
\text { toekomstig) is geborgd door } \\
\text { theoretische basis. } \\
\text { Bewerkstelligt integrale } \\
\text { biologische/fysisch- } \\
\text { chemische/hydrologische of } \\
\text { morfologische verbetering. }\end{array}$ \\
\hline & $\begin{array}{l}\text { b. } \\
\text { Duurzaamheid }\end{array}$ & $\begin{array}{l}\text { Zo gering } \\
\text { mogelijke } \\
\text { verstoring van het } \\
\text { systeem en brengt } \\
\text { het systeem in een } \\
\text { toestand waarin }\end{array}$ & $\begin{array}{l}\text { - } \quad \text { Bronaanpak kiezen i.p.v. } \\
\text { effectgerichte maatregelen. } \\
\text { - } \quad \text { Streven naar lage frequentie } \\
\text { interventie, lange }\end{array}$ \\
\hline
\end{tabular}




\begin{tabular}{|c|c|c|c|}
\hline \multirow[t]{2}{*}{ Fase } & Bouwsteen & $\begin{array}{l}\text { Waarom } \\
\text { belangrijk? }\end{array}$ & $\begin{array}{l}\text { Onderdelen binnen deze } \\
\text { bouwsteen }\end{array}$ \\
\hline & & $\begin{array}{l}\text { amper moet } \\
\text { worden } \\
\text { ingegrepen. }\end{array}$ & $\begin{array}{l}\text { levensduur/effect interventie, } \\
\text { veel oppervlakte/lengte. } \\
\text { Gebruik maken van/ruimte geven } \\
\text { aan natuurlijke processen: } \\
\text { "Bouwen-met-natuur". }\end{array}$ \\
\hline \multirow[t]{2}{*}{ 3. Creëren draagvlak } & $\begin{array}{l}\text { a. Business } \\
\text { case }\end{array}$ & $\begin{array}{l}\text { Vergroot de kans } \\
\text { op uitvoering en } \\
\text { vergroot het } \\
\text { financieel } \\
\text { draagvlak voor } \\
\text { uitvoering. }\end{array}$ & $\begin{array}{l}\text { - Reductie kosten of zelfs } \\
\text { opbrengsten door project, } \\
\text { circulair ondernemen. } \\
\text { - } \quad \text { Meekoppelkansen. } \\
\text { - } \quad \text { Focus op ecosysteemdiensten. }\end{array}$ \\
\hline & $\begin{array}{l}\text { b. } \\
\text { Samenwerking }\end{array}$ & $\begin{array}{l}\text { Verbreedt het } \\
\text { maatschappelijk } \\
\text { draagvlak, } \\
\text { voorkomt } \\
\text { weerstand en } \\
\text { vergroot daarmee } \\
\text { de kans op succes. }\end{array}$ & $\begin{array}{l}\text { - Interne communicatie; } \\
\text { - } \quad \text { Stakeholders. } \\
\text { - } \quad \text { Andere waterschappen: leren van } \\
\text { elkaar. } \\
\text { - } \quad \text { Partijen buiten usual suspects } \\
\text { (verder kijken dan eigen } \\
\text { domein). } \\
\text { Burgers betrokken, citizen } \\
\text { - } \quad \text { Pcience/zichtbaar voor inwoners. } \\
\text { Positieve } \\
\text { neveneffecten/uitstralingseffecten } \\
\text { naar de omgeving. }\end{array}$ \\
\hline \multirow[t]{3}{*}{ 4. Monitoring } & $\begin{array}{l}\text { a. } \\
\text { Effectbepaling }\end{array}$ & $\begin{array}{l}\text { Meten van de } \\
\text { effectiviteit van de } \\
\text { genomen } \\
\text { maatregelen. }\end{array}$ & $\begin{array}{l}\text { - Nulmeting gedaan. } \\
\text { Tijdens en na uitvoering wordt } \\
\text { gemonitord ('vinger aan de } \\
\text { pols'). } \\
\text { - Monitoringsplan is SMART: } \\
\text { metingen uitgevoerd aan beste } \\
\text { indicatoren volgens passende } \\
\text { methodiek op het juiste moment. }\end{array}$ \\
\hline & b. Bijsturing & $\begin{array}{l}\text { Eventueel } \\
\text { bijsturen voor } \\
\text { optimaal resultaat: } \\
\text { adaptieve } \\
\text { uitvoering. }\end{array}$ & $\begin{array}{l}\text { - Regelmatige bijsturing en nazorg } \\
\text { is ingecalculeerd in project. }\end{array}$ \\
\hline & c. Extrapolatie & $\begin{array}{l}\text { Leren van het } \\
\text { project om toe te } \\
\text { passen en te } \\
\text { optimaliseren in } \\
\text { toekomstige } \\
\text { projecten. }\end{array}$ & $\begin{array}{l}\text { - Project is dupliceerbaar en } \\
\text { opschaalbaar. }\end{array}$ \\
\hline
\end{tabular}




\subsection{Toelichting bouwstenen}

\subsubsection{Doelformulering}

Het vaststellen van een probleem in een waterlichaam vindt in de meeste gevallen plaats aan de hand van een waarneming, bijvoorbeeld visueel worden afwijkingen geconstateerd ten opzichte van een referentie (goede kwaliteit of natuurlijk water) of aan de hand van metingen worden afwijkingen geconstateerd (normoverschrijdingen, plotseling verdwijnen van soorten en daarmee daling van de score op de desbetreffende KRW-maatlat). In beide gevallen is het een uiting van de onderliggende problemen. Een goede diagnose van het probleem is vervolgens essentieel om te komen tot een oplossing. De reden hiervoor is dat er in Nederland bijna altijd sprake is van multistress-situaties. Dit wil zeggen dat verschillende stressoren/knelpunten tegelijkertijd en vaak in interactie inwerken op het systeem. Bijvoorbeeld hydrologische en morfologische verstoring gaat samen met verrijking met voedingsstoffen. Het aanpakken van zo'n probleem door het uitvoeren van herstelmaatregelen is dan ook alleen effectief wanneer tenminste het belangrijkste knelpunt wordt weggenomen.

Bij het formuleren van doelen is het daarom belangrijk dat de knelpunten goed in kaart wordt gebracht, dat wil zeggen dat de stressoren in beeld zijn en ook de bijbehorende ruimtelijke schaal (habitat, traject/waterlichaam, stroomgebied) en tijdschaal (timing, frequentie, duur). Het startpunt van een herstelproject is daarom een systeemanalyse, gevolgd door een knelpuntenanalyse. Een goed voorbeeld van deze aanpak is de stroomgebiedsbrede ecologische systeemanalyse (SESA) die voor het stroomgebied van de Tungelroyse beek is uitgevoerd (Waterschap Limburg). Aan de hand van vier stappen wordt hiermee een realistisch doel geformuleerd en kunnen bijpassende maatregelen worden gekozen (Figuur 3.1).

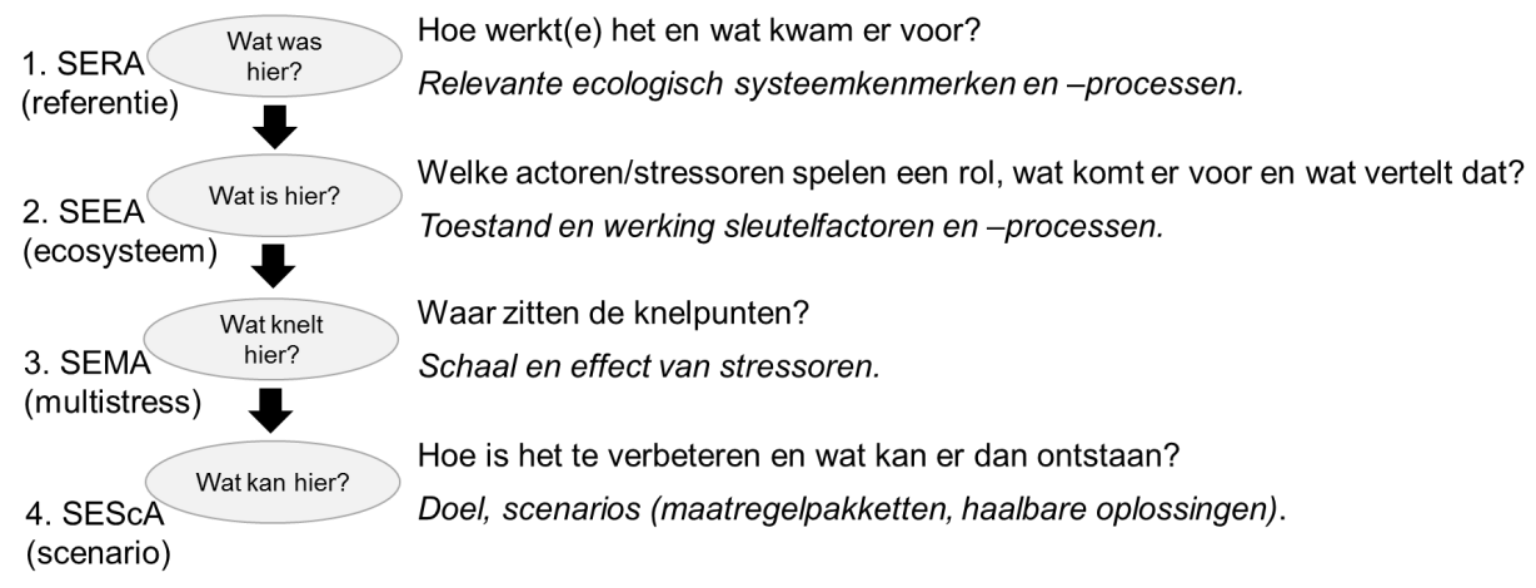

Figuur 3.1: Schematische weergave van de vier componenten van een stroomgebiedsbrede ecologische systeemanalyse van waterschap Limburg (SESA; Waterschap Limburg).

Belangrijk bij het stellen van doelen is dat deze realistisch zijn. Hierbij kan het helpen te werken met realistische streefbeelden, waarin een tijdspanne en de omvang van de kwaliteitsverbetering vooraf worden ingeschat aan de hand van de mogelijkheden en toekomstige ontwikkelingen in het gebied waar herstel beoogd wordt. 


\subsubsection{Keuze passende maatregelen}

Nadat de knelpuntenanalyse heeft de knelpunten blootgelegd en heeft aangegeven wat de relevante schaalniveaus zijn (ruimtelijk en temporeel) en hierbij doelen zijn geformuleerd, kunnen de bijpassende maatregelen worden gekozen. Voor ecologische doelen staat hierbij het organisme centraal: welke ecologische sleutelfactoren werken in op het organisme gedurende de levenscyclus en wat zijn hierbij de bandbreedtes (minimum, optimum, maximum)? Voorbeelden van ecologische sleutelfactoren zijn watertemperatuur, zuurstofgehalte, stroomsnelheid, substraat, toxicanten, licht, droogval en zuurgraad. Op sommige van de ecologische sleutelfactoren heeft het waterbeheer niet direct grip, maar werken deze door via andere factoren, bijvoorbeeld het zuurstofgehalte wordt grotendeels bepaald door de organische belasting van het systeem. Deze factoren zijn de stuurknoppen van een watersysteem. Wanneer maatregelen worden genomen is dit in de vorm van het terugdringen van organische belasting (bijvoorbeeld saneren rioolwateroverstorten, terugdringen sliblast). Belangrijk is dat wanneer één sleutelfactor na uitvoering van de maatregelen niet op orde is, de doelorganismen zich niet kunnen vestigen en er dus geen effect gemeten kan worden.

Omdat er gewoonlijk sprake is van multistress-situaties, is het nemen van een enkele maatregel vaak niet afdoende om een verbetering van de kwaliteit te bewerkstelligen. Er zijn daarom meestal maatregelpakketten nodig. Hierbij is het realistische doel (zie vorige paragraaf) leidend; in sommige gebieden zijn meer mogelijkheden dan in andere, waardoor het kiezen van maatregelpakketten maatwerk is. Wel zijn er een aantal factoren die de effectiviteit verhogen:

- De slagingskans van een herstelproject wordt groter wanneer er een goede onderbouwing is voor de maatregelkeuze, gebaseerd op onderzoek (wetenschappelijk geborgde theoretische basis).

- Een maatregel die integraal verbeteringen geeft op biologisch/fysisch-chemisch/hydrologisch of morfologisch vlak (bijv. aanleggen van bosstroken langs beken, grijpt in op o.a. licht, substraat, temperatuur, voedingsstoffen) heeft meer effect dan een sterk op een factor gerichte maatregel (bijv. soortgerichte maatregelen, zoals het aanleggen van grindbedden in beken).

$\mathrm{Er}$ is binnen maatregelen om de waterkwaliteit te verbeteren een belangrijk onderscheid te maken tussen brongerichte maatregelen en mitigerende maatregelen. Het eerste type maatregelen neemt de oorzaak weg van de problemen in het watersysteem, bijvoorbeeld het saneren van rioolwateroverstorten en het omzetten van landbouwgrond in natuur. Het tweede type is effectgericht, het neemt de bron niet weg van de problemen, maar zorgt ervoor dat de effecten verminderd worden. Een voorbeeld hiervan is het beschaduwen van een te voedselrijke watergang. Door het gebrek aan licht komt de massale waterplantengroei niet op gang, die in een onbeschaduwde situatie voor problemen zou zorgen. Een ander voorbeeld is het toedienen van zuurstof in een plas waar het zuurstofgehalte in de zomer te ver daalt.

Ingrepen zouden duurzaam moeten zijn, brongericht, een zo laag mogelijke interventiefrequentie en een zo lang mogelijke levensduur. Idealiter leidt een eenmalige ingreep tot een langdurig en een zichzelf in stand houdend effect. Te vaak ingrijpen kan namelijk leiden tot een te frequente verstoring van het watersysteem, waardoor dit uit evenwicht raakt en er allerlei onverwachte en/of negatieve effecten kunnen optreden. Vaak zijn in een project in het eerste jaar na een ingreep explosieve toenames te zien van bepaalde dier- en plantensoorten. Exoten zijn berucht in dit opzicht, omdat deze vaak de vrijgekomen ruimte bezetten.

Een grote omvang van het project, in termen van oppervlakte (veel sloten, complete bovenloop, beekdalbreed etc.) vergroot de effectiviteit en duurzaamheid. Veel oppervlakte/lengte heeft een stabiliserend effect, het systeem wordt robuuster (groot oppervlak wordt minder snel beïnvloed) en 
veerkrachtiger (als een deel verstoord wordt kan de rest van het gebied als bron van herstel optreden) wanneer er een onverwachte verstoring optreedt.

Het wordt steeds duidelijker dat duurzame maatregelen die maatregelen zijn die inspelen op de natuurlijke geohydrologische, -morfologische, -chemische en ecologische processen. Zoals gesteld in de (Water in Brabant visie 2030): "De wateropgaven anno 2017 laten zien dat de natuurlijke en (geo/hydro)morfologische processen sterker zijn en meer oplossingen bieden dan techniek en beheersbaarheid" Dit wordt building-with-nature oftewel bouwen-met-natuur genoemd. De toepassing van dit type maatregelen is sterk in opmars.

\subsubsection{Creëren draagvlak}

Om een project met daarbinnen de juiste maatregelen daadwerkelijk te kunnen uitvoeren, is draagvlak nodig. Samenwerking is hierin essentieel. Draagvlak kan worden gecreëerd op financieel vlak, bijvoorbeeld via het ontwikkelen van een business case. Verder kan intern of maatschappelijk draagvlak vergroot worden door samen te werken.

Een herstelproject is gebaat bij goede interne communicatie, zowel binnen een waterschap als tussen de waterschappen. Afstemming tussen verschillende onderdelen van een organisatie is cruciaal, bijvoorbeeld wanneer een herstelproject wordt uitgevoerd en vervolgens vergeten wordt het beheer en onderhoud van de watergang hierop aan te passen dan kunnen alle effecten met een onderhoudsronde teniet gedaan worden. Een manier om dit soort problemen te voorkomen is het vormen van integrale projectteams bij herstelprojecten, met hierin bijvoorbeeld een ecoloog, hydroloog, gebiedsbeheerder en beleidsmedewerker. Veel problemen met waterkwaliteit spelen door het hele land en de maatregelen die ingezet worden zijn vaak niet uniek. Het is belangrijk om met elkaar hierover in gesprek te gaan, zodat er van elkaar geleerd kan worden.

Verder is communicatie naar buiten toe essentieel, uitleggen waarom maatregelen worden genomen en wat de effecten zijn is belangrijk voor het krijgen van draagvlak, net zoals het direct betrekken van belanghebbenden (bijv. aangelanden, inwoners). Betrekken van stakeholders (lagere overheden, terreinbeherende organisaties, recreatieschappen etc.) bij de plannen is noodzakelijk, maar ook het verder kijken buiten het eigen domein kan kansen en nieuwe samenwerkingen opleveren. Dit laatste is vooral belangrijk voor zaken als circulariteit en meekoppelkansen.

Een reductie van de kosten of zelfs het genereren van opbrengsten door uitvoering van een herstelproject kan worden ingestoken via de circulariteitsgedachte en meekoppelkansen. Bij de uitvoering van projecten en het onderhoud van watergangen komt vaak veel plantenmateriaal vrij. Dit kan worden gebruikt voor andere doeleinden, bijvoorbeeld om andere stoffen uit te winnen. Door deze stoffen om te zetten in nieuwe producten, wordt afval omgezet iets bruikbaars (business case; verwaarding van restproducten). Meekoppelkansen kunnen sterk kosten-reducerend werken. Zo werd bij het zandsuppletieproject in de Leuvenumse beek (Waterschap Vallei en Veluwe) zand gebruikt dat was vrijgekomen bij een stuifzand-regeneratieproject in de directe omgeving (Figuur 3.2). Hierdoor hoefde geen zand van elders aangevoerd te worden.

Ecosysteemdiensten kunnen tenslotte een verbindende factor vormen tussen het watersysteem en de processen die zich hierin afspelen en het genereren van opbrengsten, variërend van zuivering tot recreatieve waarde. 


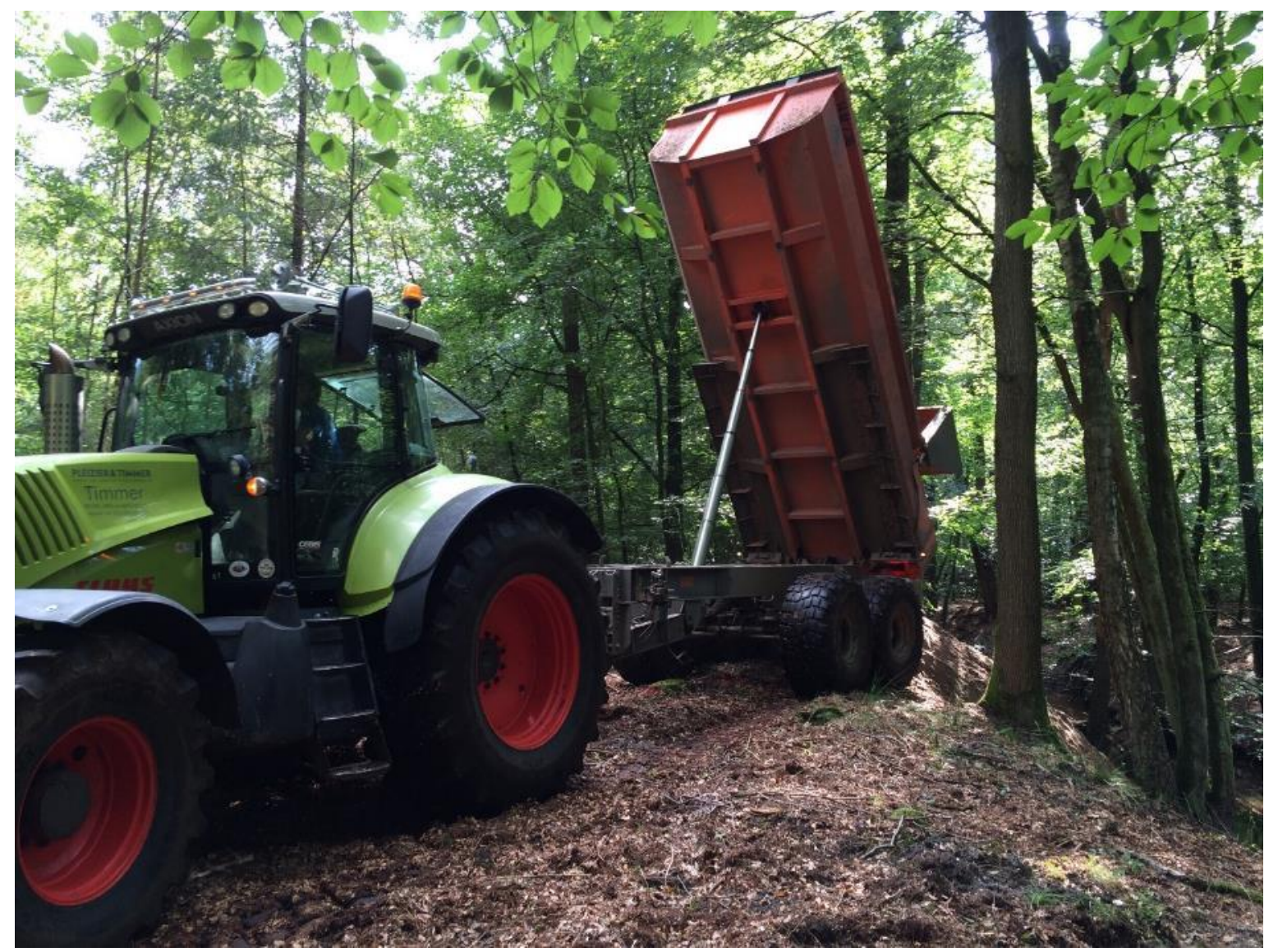

Figuur 3.2: Voorbeeld van een meekoppel-kans in een beekherstelproject in de Leuvenumse beek (Waterschap Vallei en Veluwe, Natuurmonumenten). Bij het suppleren van zand in de beek werd materiaal gebruikt dat was vrijgekomen bij een stuifzand-regeneratieproject in de buurt, waardoor geen zand van elders hoefde worden aangevoerd. Foto: Maarten Veldhuis.

\subsubsection{Monitoring}

In veel herstelprojecten ligt de nadruk op de uitvoering van het project, terwijl de monitoring van de effectiviteit weinig aandacht krijgt. Gevolg is dat er in de meeste gevallen niet of met een te lage frequentie gemeten wordt om de doelrealisatie, mits die meetbaar is geformuleerd, in beeld te krijgen op een statistisch onderbouwde manier.

Het probleem zit hem vaak in het ontwerp van het meetprogramma, waarbij controlemeetpunten en metingen voorafgaand aan maatregelen (nulmetingen) niet worden opgenomen. Vooral de controles zijn cruciaal voor het meten van effecten van herstelmaatregelen, want als een ontwikkeling overal plaatsvindt dan kan deze natuurlijk niet, in positieve of negatieve zin, toegeschreven worden aan het uitvoeren van het herstelproject. Het meest optimale meetprogramma is het 'voor-na-controle-impact'ontwerp (BACI). Hierin wordt zowel in een controle traject/waterlichaam en een het traject/waterlichaam met de maatregel zowel voorafgaand als na uitvoering gemeten. Dit meetprogramma wordt zelden toegepast door waterbeheerders, maar recentelijk wel gezamenlijk door de waterschappen in NoordBrabant om de effecten van het inbrengen van dood hout en het extensiever maaien in beken te onderzoeken (project Kleinschalige maatregelen; waterschappen Aa en Maas, de Dommel en Brabantse Delta, Figuur 3.3). Het is belangrijk zo'n monitoringsprogramma al voorafgaand aan het project scherp te 
hebben (SMART), waar wordt gemeten en hoeveel herhalingen zijn er nodig om een statistisch onderbouwde uitspraak te kunnen doen over de effectiviteit? De reden hiervoor is dat het vergeten van meetpunten of het gedurende de looptijd wijzigen van de opzet leidt een afname van de statistische zeggingskracht van zo'n meetprogramma.

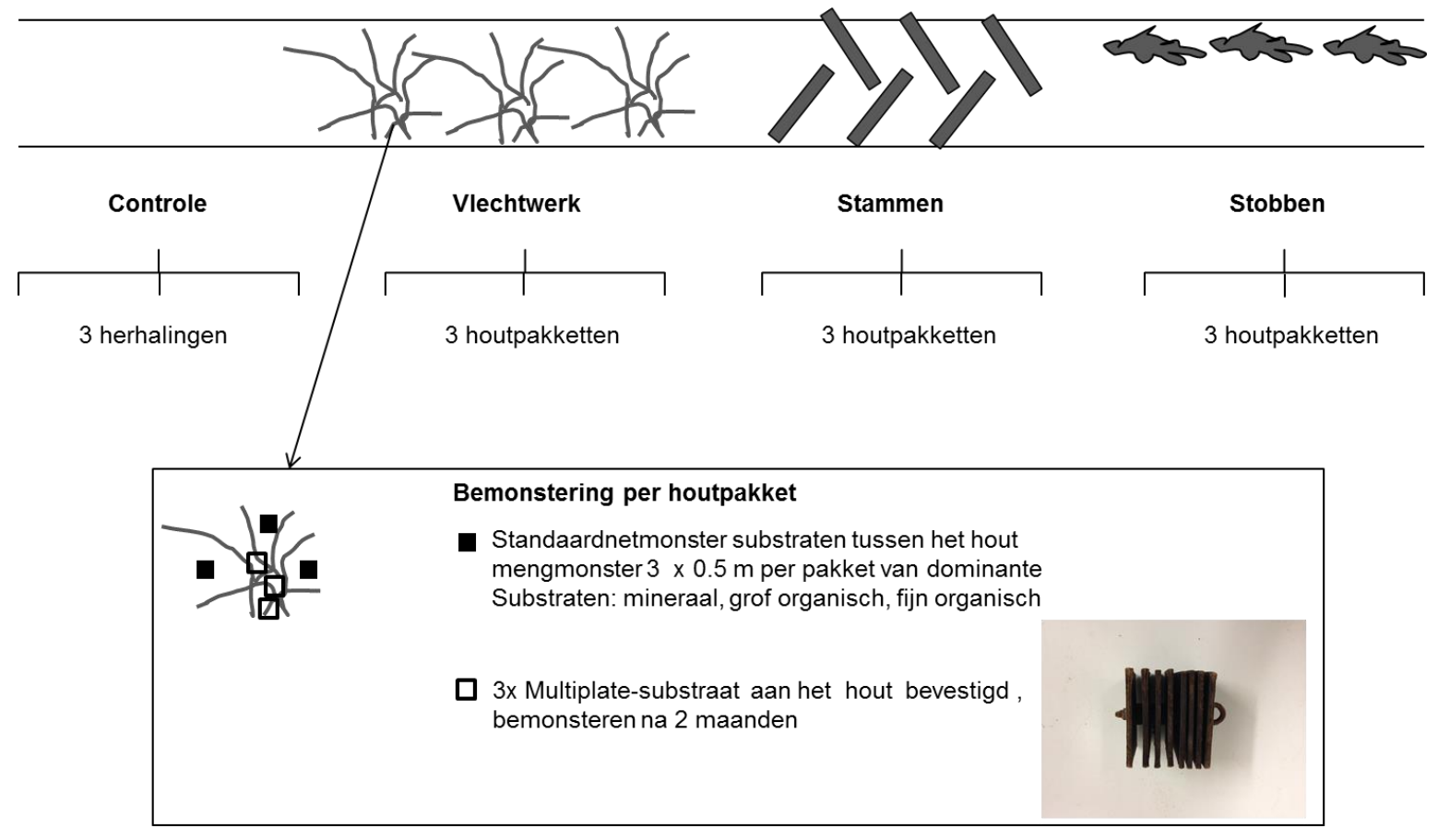

Figuur 3.3: Voorbeeld van een monitoringprotocol binnen het project "Kleinschalige maatregelen in Brabantse beken" (Waterschap de Dommel, Aa en Maas, Brabantse Delta) met als doel te onderzoeken wat de effectiviteit is van verschillende typen houtpakketten. Er zijn 4 behandelingen: controle, vlechtwerk, stammen en stobben, waarvan in elke beek 3 pakketten bemonsterd worden (replica's) met twee technieken: netbemonstering en kunstmatig substraat.

Een ander probleem is dat er soms wel gemeten wordt, maar niet de parameters die geschikt zijn voor het vaststellen van de doelrealisatie. Dit hoeven niet de verkeerde parameters te zijn, maar dit kan ook het gevolg zijn van hoe er gemeten wordt. Een voorbeeld hiervan is het standaard meten van de zuurstofconcentratie van het water gedurende de dag, terwijl het kritieke moment voor de fauna gedurende de nacht optreedt. Uiteraard is het de bedoeling op een zo efficiënt mogelijke (en kosteneffectieve) manier relevante informatie te verzamelen: wat er gemeten wordt hoeft alleen aan te sluiten bij de vraag of het doel.

In sommige gevallen is er nog niet veel ervaring met een maatregel, zoals de zandsuppletie van waterschap Vallei en Veluwe, Figuur 3.3), waardoor een 'vinger aan de pols'-aanpak nodig is om het proces te optimaliseren. Daarnaast hebben ecosystemen altijd een zekere onvoorspelbaarheid in zich, zowel door externe (bijvoorbeeld een extreem droog jaar tijdens uitvoering) als interne processen (er is nog veel niet bekend over bijvoorbeeld interacties tussen processen, waardoor onverwachte ontwikkelingen kunnen optreden). Het is dus belangrijk tijdens en na uitvoering van een project de ontwikkelingen te volgen en eventueel bij te sturen als er signalen zijn dat er iets verkeerd gaat. Dit betekent dus ook dat dit ingecalculeerd moet zijn in het project.

Een project dat dupliceerbaar en daarmee opschaalbaar is, kan uiteindelijk een veel groter effect hebben. Om dit te bereiken is het vastleggen/documenteren van het proces en de stappen die doorlopen zijn 
belangrijk. Naast een goed projectplan en monitoringsprogramma moet ook goed worden vastgelegd wat en wanneer is gedaan ten tijde van uitvoering. Deze bouwsteen heeft daarmee veel raakvlakken met andere bouwstenen, van communicatie tot monitoring. Soms gaat opschaling vanzelf, wanneer een project positieve neveneffecten/uitstralingseffecten naar de omgeving heeft. Dit kan een fysiek effect op het systeem zijn, bijvoorbeeld een ingreep in het water geeft gevolgen voor het aanliggende gebied (bijv. beekdalbreed), maar ook kan een project inspirerend werken voor aangelanden of andere belanghebbenden, die vervolgens zelf ook initiatieven gaan ontplooien.

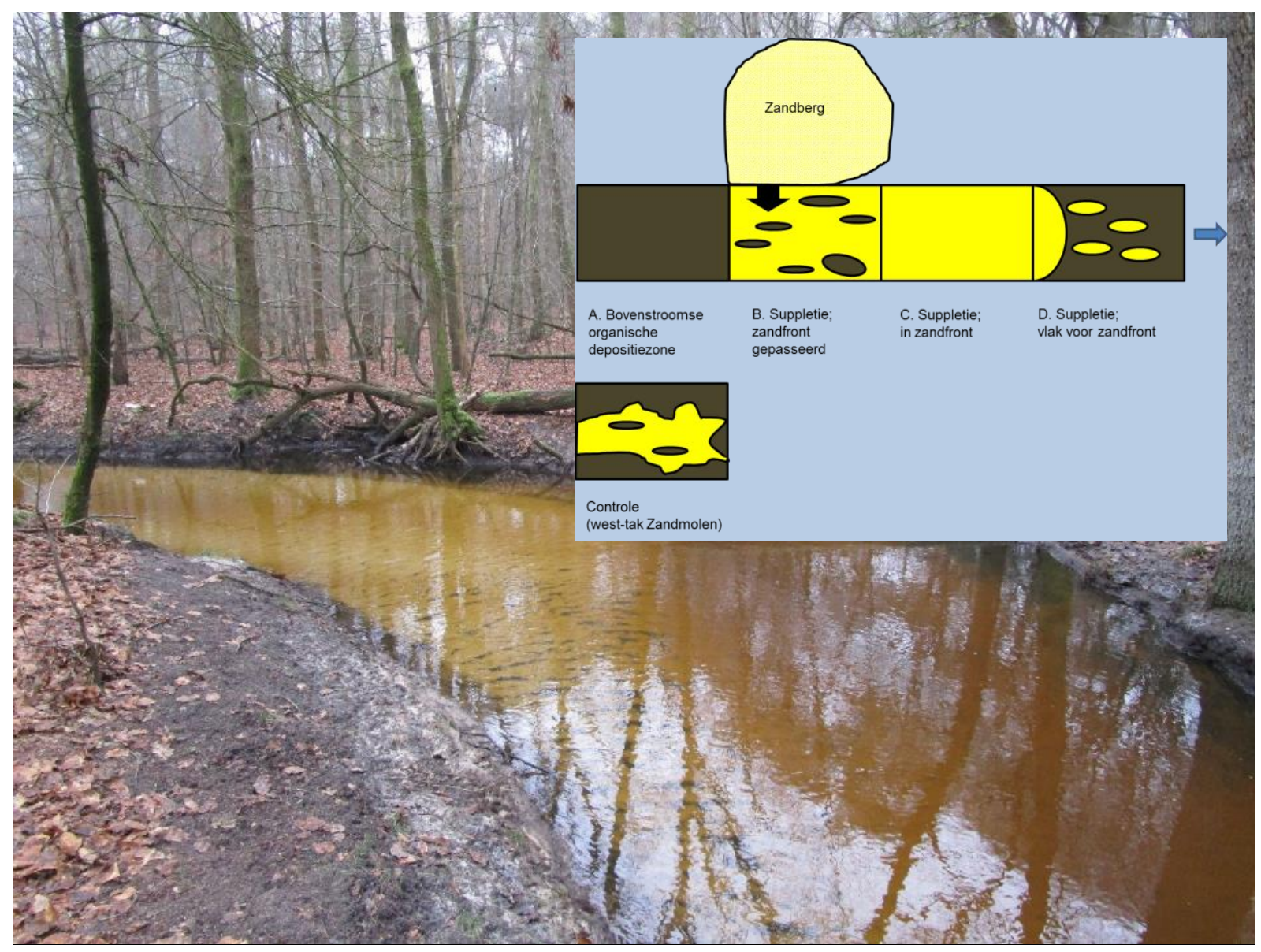

Figuur 3.3: In de Leuvenumse beek (Waterschap Vallei en Veluwe) is een monitoringsprogramma opgezet om de effecten van de nieuwe beekherstelmaatregel zandsuppletie op de aanwezige levensgemeenschap te kunnen volgen om eventueel te bij te sturen wanneer er een ongewenst effect op zou treden. 


\section{Overzicht aangeleverde projecten}

\subsection{Respons waterschappen}

Waterschaps-ecologen en beleidsmedewerkers zijn aangeschreven in de week van 11-15 juni 2018. Van de 21 waterschappen hebben uiteindelijk 11 waterschappen gegevens aangeleverd. Wat betreft de representativiteit is de spreiding van de projecten evenwichtig verdeeld over het land, waardoor verschillende fysisch-geografische regio's (met bijbehorende milieuomstandigheden, zoals grondsoort, zoutinvloed en verhang) in de dataset vertegenwoordigd zijn (Figuur 4.1).

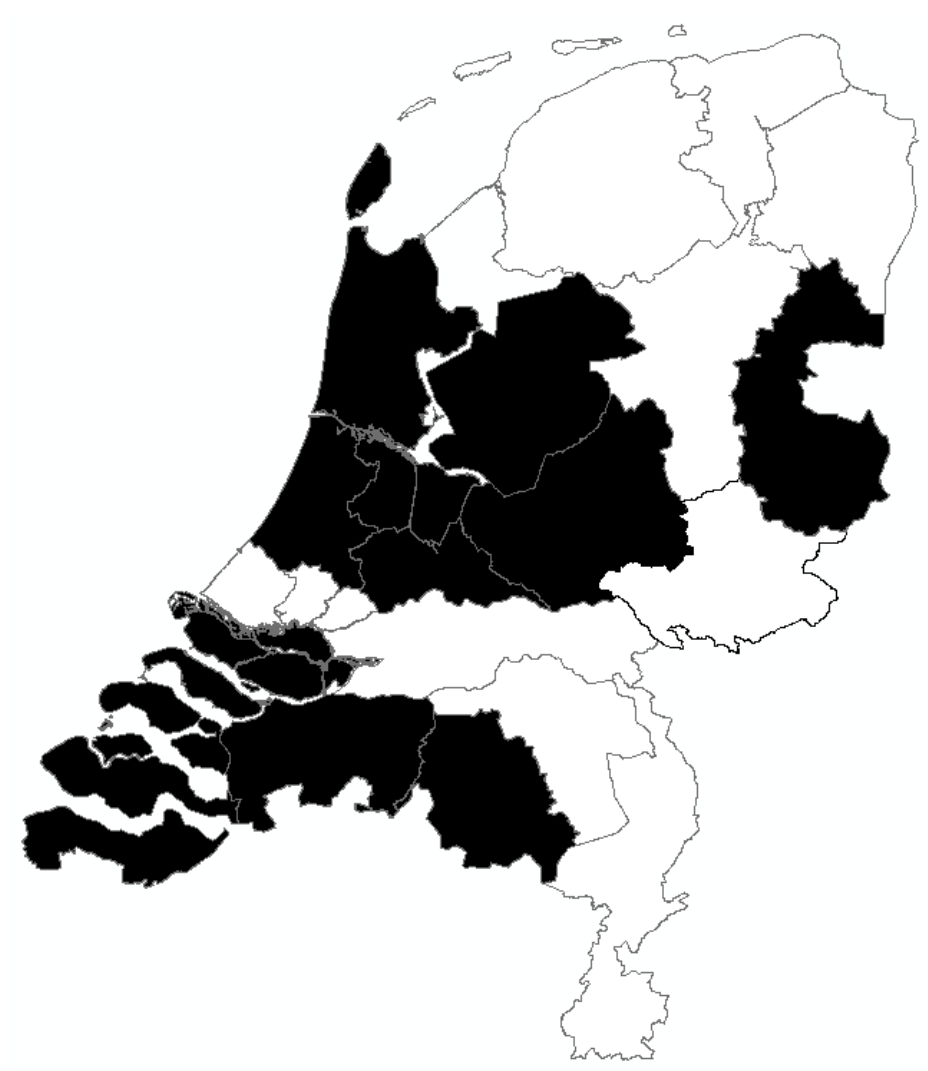

Figuur 4.1: Waterschappen die projectinformatie hebben aangeleverd (zwart). Contouren geven de waterschapsgrenzen aan.

\subsection{Korte beschrijving aangeleverde projecten}

Er zijn korte samenvattingen gemaakt van de door de waterschapmedewerkers geselecteerde projecten. $\mathrm{Er}$ is hierbij onderscheid gemaakt tussen projecten in KRW-wateren en overige projecten. Overige projecten kunnen in de overige wateren zijn uitgevoerd, maar kunnen ook andere initiatieven omvatten. Een uitgebreide beschrijving per project is opgenomen in Bijlage 1. 


\subsubsection{Hoogheemraadschap Hollands Noorderkwartier}

\section{$\underline{\text { KRW-projecten }}$}

Watersysteemanalyses

Om realistische KRW-doelen op maat te kunnen formuleren, wordt een gedegen watersysteemanalyse uitgevoerd voor alle KRW-waterlichamen en wordt de status van de ecologische sleutelfactoren beoordeeld om te komen tot verbeteringsmaatregelen.

Samenwerking bodem en water

Samenwerkingsproject om agrarische ondernemers te stimuleren (coaching, subsidie) maatregelen te treffen om emissies naar oppervlaktewater van nutriënten en gewasbeschermingsmiddelen te verminderen en om zuinig gebruik van zoet water bevorderen.

Citizen Science monitoring waterkwaliteit

Vrijwilligers monitoren natuurvriendelijke oevers op flora en fauna. Sinds dit jaar doen ze dit met hulp van de Waterbox, waarmee ze zelf de waterkwaliteit kunnen meten. Hiermee wordt getracht draagvlak en waterbewustzijn te vergroten.

Monitoring vismigratie Noordzeekanaalgebied

Het merken van vissen (VIE-tags) om te zien hoe ze zich verspreiden door het gebied.

\section{Overige projecten}

EOMORES-project Algenradar in 't Twiske

Het opzetten van een voorspellingsmodel voor blauwalgenbloei om zwemmers tijdig te kunnen informeren.

\section{Inzet onderwaterdrone}

Voor het project Algenradar (zie hierboven) wordt er geëxperimenteerd met een onderwaterdrone die vlakdekkende waterkwaliteitsmetingen uitvoert.

Toepassing eDNA voedselwebanalyses voor toestandsbepaling en systeembegrip

Het met slechts één watermonster verkrijgen van een integraal beeld van het leven onder water (het voedselweb) door het toepassen van eDNA. Deze vorm van monitoring is goedkoper, sneller, robuuster en veel completer dan conventionele monitoring.

\subsubsection{Waterschap Hollandse Delta}

\section{KRW-projecten}

De Blauwe Verbinding

De Blauwe Verbinding verbindt verschillende zwemplassen en het Zuiderpark in Rotterdam, zodat deze met zoet en schoon water vanuit de Oude Maas kunnen worden doorgespoeld ten behoeve van verbetering van de waterkwaliteit (terugdringen blauwalgen, tegengaan verzilting) en recreatie (kanoverbinding). 
Vegetatie-onderzoek Goeree-Overflakkee

Troebelheid, verzilting, exoten en veel nutriënten zorgen ervoor dat er weinig of geen bedekking is met ondergedoken waterplanten in veel waterlichamen binnen het beheergebied. Er wordt onderzocht welke oorzaak of oorzaken er zijn die ervoor zorgen dat de groei van ondergedoken waterplanten achterblijft, door in het veld (exclosures, impact vraat, creëren luwte) en laboratorium (effect van zout, kiemkracht zaadbank) experimenten te doen.

Overige projecten

Oostvoornse Meer (wel KRW-waterlichaam, maar geen KRW probleem)

Om inzicht te krijgen in de oorzaken van de toegenomen problemen met benthische blauwalgen en om maatregelen te onderbouwen is met behulp van exclosures onderzocht wat het effect is van het massaal voorkomen van de exotische zwartbekgrondels op de benthische blauwalgen. Verder is gekeken wat de effecten zijn van maaien van de ondergedoken waterplanten op het voorkomen benthische blauwalgen en worden experimenten uitgevoerd door matten van benthische blauwalgen te bedekken met zand.

Het gebruik van een waterdrone die zwerfvuil opruimt uit oppervlaktewater (o.a. plastics)

Er wordt geëxperimenteerd met een aquadrone bij het schoonmaken van sloten en singels in de stad. De zogeheten WasteShark wordt ingezet om (plastic) afval en kroos te verzamelen.

\subsubsection{Waterschap Zuiderzeeland}

\section{KRW-projecten}

\section{Robuuste herinrichting Hoge Dwarsvaart}

Herinrichting door middel van vergraving van de oevers van de Vaart om een substantieel areaal natte natuur toe te voegen aan de provinciale EHS.

\section{Overige projecten}

Geen opgave.

\subsubsection{Hoogheemraadschap Rijnland}

\section{$\underline{\mathrm{KRW} \text {-projecten }}$}

Reeuwijkse plassen

Intensieve monitoring van maatregelen: 1. instellen natuurlijker waterpeil, 2. slibmaatregelen (baggeren, toevoegen ijzerchloride om voedingsstoffen in het slib te binden), 3. afkoppelen voedselrijke waterstromen uit de polders van de plassen en 4. aanleg en onderhoud natuurvriendelijke oevers om kennis op te doen en de effecten van afzonderlijke maatregelen in beeld te brengen.

\section{Overige projecten}


Een betere waterkwaliteit in de bollenteelt door ijzerzand

Het gebruik van zand met een laagje ijzeroxide (restproduct drinkwaterwinning) wat fosfaat bindt. Door drainagewater via een filter met ijzerzand te lozen wordt het slootwater in het bollengebied minder verontreinigd met fosfaat.

\subsubsection{Waterschap Vechtstromen}

\section{$\underline{\text { KRW-projecten }}$}

\section{Beneden Regge}

Het over een lengte van circa zes kilometer herstellen van een dynamisch en veerkrachtig benedenloopsysteem. De oorspronkelijk rivierloop en de verbinding met het dal zijn hersteld door het verondiepen en versmallen van het zomerbed, waardoor bij piekafvoer water in het dal kan worden geborgen. Daarbij worden zomer- en winterbed extensief beheerd.

\section{Hagmolenbeek (project Twickel)}

Over circa vier km is de beek hersteld in de vorm van een natuurlijk functionerend beeksysteem, m.a.w. een vrij afstromende, natuurlijke weidebeek, waarbij het beekprofiel sterk versmald en verontdiept is. Het surplus aan oppervlaktewater wordt in het dal geborgen. Beek, dal en aanliggende gronden worden extensief beheerd.

\section{Deurningerbeek}

De beek is heringericht als vrij afstromende, natuurlijke bosbeek. Hiervoor is het beekprofiel sterk versmald en verontdiept en zijn de aanliggende natuurstroken met overwegend hout bezet en worden extensief beheerd. Het surplus aan oppervlaktewater wordt beekdalbreed geborgen.

Overige projecten

Geen opgave.

\subsubsection{Hoogheemraadschap De Stichtse Rijnlanden}

\section{KRW-projecten}

\section{Vismigratie Rijn-west}

Onderzoek naar regionale en lokale vismigratie in poldersystemen, het vaststellen van het belang van overig water voor de visstand en het beter inzicht krijgen in het effect van vismigratiemaatregelen.

\section{Modelonderzoek vispassage}

Op basis van modelonderzoek wordt de invloed van de stroomsnelheid en turbulentie en de mogelijke implicaties daarvan op de passeerbaarheid voor verschillende vissoorten onderzocht.

\section{Nevengeul Kromme Rijn bij Odijk}

Het aanleggen van een nevengeul, met hierin verschillende soorten substraat (o.a. ingebracht dood hout) om zo habitatdiversiteit te krijgen en om plaatselijk stroomversnellingen te doen ontstaan die (rheofiele) soorten ten goede kunnen komen. 
Waterkwaliteitsmodule Tygron Engine

Model om snel en accuraat tot een gebiedsdekkende, ruimtelijke gedetailleerde watersysteemanalyse (water- en stoffenbalans) te komen, m.a.w. een jaarrond inzicht in de actuele en kritische nutriëntenbelastingen per sloot (dus niet alleen waterlichamen, maar ook het overige water).

\section{Overige projecten}

\section{Aquafarm}

Aquafarm is een nieuw initiatief op het gebied van waterzuivering waarin rioolwater gezien en behandeld wordt als grondstof waarop planten en dieren kunnen groeien, nutriënten en milieuvreemde stoffen onttrekken en nieuwe stoffen produceren. In een cascade van planten en dieren wordt het rioolwater stapsgewijs omgezet in (hoog)waardige producten.

\section{De boerensloot leeft}

Agrariërs hebben inmiddels al meerdere jaren een alternatief (natuurlijker) beheer en onderhoud toegepast. In overleg met het agrarisch collectief worden deze sloten door vrijwilligers en AQUON waterlaboratorium gemonitord. Zo kan gevolgd worden wat het effect is van het natuurlijker beheer en hoe dit beheer zo nodig aangepast kan worden.

\subsubsection{Waterschap de Dommel}

\section{$\underline{\text { KRW-projecten }}$}

\section{Herkomst nutriënten Reuseldal}

Systeemonderzoek naar de herkomst van nutriënten in de Reusel met behulp van stroombaanberekeningen en de KRW-verkenner, zodat gericht waterkwaliteitsmaatregelen kunnen worden gedefinieerd.

Kleinschalige maatregelen, resultaten tongelreep, dood hout in de beek Dood hout inbreng Tongelreep (en/of Beekloop) Er wordt geëxperimenteerd met het inbrengen van verschillende typen dood hout pakketten om stromingscondities en habitatvariatie te verbeteren. Effect wordt in de tijd gevolgd. Intern is tevens het gesprek op gang gekomen hoe het beheer van een natuurlijke beek eruit kan zien.

\section{Overige projecten}

Doelen overig; macrofyten inventarisatie Veldmethode KRW-beoordeling macrofyten overige wateren t.b.v. waterkwaliteitsspoor.

Ontwikkeling van een veldmethode om sloten waarop rioolwateroverstorten uitkomen te beoordelen op de KRW-doelstelling voor Overig water. Hiervoor wordt de beoordeling van de groeivormen macrofyten (totale bedekking van vijf groeivormen in het water, ongeacht welke soorten daarin voorkomen) en een inschatting van de beoordeling van de soortensamenstelling op basis van een selectie van soorten gebruikt.

\subsubsection{Waterschap Amstel, Gooi en Vecht}

\section{KRW-projecten}


De Vecht

Terugdringen negatieve effecten van woonboten en recreatievaart op waterkwaliteit, oevers en landschapsbeleving langs het riviertje de Vecht. Via aanleggen natuurvriendelijke oevers, verplaatsen van woonboten zodat natuur, landschap en cultuurhistorisch kwetsbare locaties worden ontzien, afspraken om verdere toename van woonboten en bebouwing te voorkomen, aanpassen vaarsnelheid, aanleg openbare ligplaatsen en vuil-inleverpunten. Om de waterkwaliteit te verbeteren is de zwaar verontreinigde waterbodem over de gehele lengte van de Vecht gesaneerd en vindt renovatie van rioolwaterzuiveringsinstallaties plaats.

Oxidatie van het hypolimnion als defosfateringssysteem in de Ouderkerkerplas

In deze diepe zandwinput met thermische stratificatie vindt in de zomer door energiebedrijf Nuon koudwaterwinning plaats om bedrijfsgebouwen te koelen. Als alternatief voor de traditionele, individuele koelmachines zorgt dit collectieve systeem voor energiebesparing en verlaging van $\mathrm{CO}_{2}$-uitstoot (circa 75 procent reductie). Na het koelproces wordt het gebruikte water boven in de plas teruggebracht. Om te voorkomen dat door deze activiteit de waterkwaliteit in de Ouderkerkerplas verslechtert, stelt het waterschap eisen aan de lozing, bijvoorbeeld aan de maximale fosfaatvracht Om aan de normen te voldoen heeft Nuon een innovatieve zuurstof toevoer-systeem aangelegd op de bodem van de plas. Het zuurstof zorgt ervoor dat fosfaat zich aan de bodem bindt door oxidatie van gereduceerd ijzer, waardoor dit samen met fosfaat neerslaat. Hierdoor verbetert de waterkwaliteit en wordt algenbloei tegengegaan.

\section{Overige projecten}

Geen opgave.

\subsubsection{Waterschap Vallei en Veluwe}

\section{KRW-projecten}

\section{Synergieproject Impuls Hierdense Beek}

Integraal beekherstel waarin door piekafvoeren uit bovenstrooms landbouwgebied veroorzaakte problemen als een te diepe insnijding, ontkoppeling van beek-beekdal, te weinig structuurvariatie, droogval, te hoge voedselrijkdom worden aangepakt. Door het aanbrengen houtpakketten, zandinbreng, aantakken oude beeklopen en overstromingszones en het herstel van kwelgebied wordt gestreefd naar het herstel van een zo natuurlijk mogelijk functionerende laaglandbeek, waarbij de relatie tussen beek en omgeving (beekdal) is hersteld en er ecologisch waardevolle gradiënten zijn ontwikkeld.

\section{Aanleg beekbegeleidende zone Modderbeek}

Ten behoeve van waterberging en ecologie ontwikkelen van een vrij meanderend beektraject met een heterogene bodem en oever met een brede beekbegeleidende laagte die voor de helft tot volledig is beschaduwd. Voorafgaand aan de uitvoering heeft er een grote vrijwillige kavelruil plaatsgevonden om beschikbare grond binnen een aaneengesloten 40 meter brede strook te krijgen over een lengte van 6 kilometer.

\section{$\underline{\text { Overige projecten }}$}

Gecombineerd ecologische en cultuurhistorisch herstel sprengenstelsel Vaassense beken Het inrichten en onderhouden van een sprengenbekencluster ten behoeve van zowel ecologie als cultuurhistorie. Er zijn zowel maatregelen genomen ten behoeve van ecologisch herstel (herstel morfologie en hydrologie, beschaduwing, stimuleren substraatvariatie, vispasseerbaarheid, saneren 
rioolwateroverstorten) als op cultuurhistorisch vlak (molenplaatsen, wijerds, aflaten en opgeleide trajecten). Het beekherstel heeft plaatsgevonden in de vorm van interactieve uitvoering, waarbij de omgeving nauw betrokken is geweest bij invulling van de plannen.

\subsubsection{Waterschap Scheldestromen}

\section{KRW-projecten}

Vispassages tussen binnen- en buitenwateren

Aanleggen van vispassages tussen zoute buitenwateren en brakke binnenwateren ten behoeve van vissoorten die in verschillende levensfasen deze watertypen gebruiken.

\section{Natuurvriendelijke oevers}

Om de morfologie in de waterlopen te verbeteren, habitat voor schuilen, paaien en foerageren voor macrofauna en vis te creëren, drift van bestrijdingsmiddelen te reduceren vanaf landbouwpercelen en voedingsstoffen uit het water te onttrekken worden natuurvriendelijke oevers aangelegd.

Toekomstige aanpak

Voor de brakke wateren wordt in kaart gebracht welke doelsoorten te verwachten zijn en wat deze soorten nodig hebben op het gebied van inrichting/morfologie, zodat maatregelen getroffen kunnen worden als bepaalde onderdelen ontbreken.

Overige projecten

Geen opgave.

\subsubsection{Waterschap Brabantse Delta}

\section{$\underline{\text { KRW-projecten }}$}

\section{Boven Donge - meander Leijkant}

Om ook bij lage afvoeren continue stroming te houden, substraatvariatie te stimuleren en een vismigratieknelpunt (stuw) op te lossen is als omleiding van de stuw een nieuwe geul met een smal profiel gegraven en zijn de aanliggende percelen ingericht als ecologische verbindingszone.

Binnenschelde - snoekpaaigebied

Realiseren snoekpaaigebied in plas. Door de aanwas aan snoek te stimuleren kan vertroebeling water en verlies waterplanten door bodemwoelende vissen voorkomen worden en daarmee verlies ecologische kwaliteit KRW. Daarnaast blijft hierdoor de recreatieve waarde van de plas hoog.

\section{Overige projecten}

Verbetering waterkwaliteit stadswater Groote Melanen

Terugdringen van externe en interne belasting van fosfor in stedelijk water om het risico op blauwalgenbloeien structureel terug te dringen, het risico op wintervissterfte te verminderen en de helderheid van het water te laten toenemen met groeimogelijkheden voor ondergedoken waterplanten. 
Maatregelpakket extern: omleiden verontreinigd water, verminderen van de bladinval door herinrichting oevers, voorlichting gebruikers. Intern: afvissen bodemwoelende vis, baggeren waterbodem en afdekken met schoon zand met een fosfaatbindend middel op basis van bentoniet (commercieel beschikbaar als Phoslock $($ ), toevoegen vloeibaar vlokmiddel (polyaluminiumchloride) aan water om algen en opgeloste fosfaten uit het water te verwijderen.

Verbetering waterkwaliteit zwemplas De Kuil

Terugdringen van blauwalgenbloei in zwemwater veroorzaakt door interne belasting door het inzetten van een combinatie van een vloeibaar vlokmiddel (ijzer(III)chloride) en een vast fosfaatbindend middel op basis van bentoniet (commercieel beschikbaar als Phoslock $®$ ). Deze gecombineerde aanpak (Flock \& Lock) verwijderde de blauwalgen uit het water en onderschepte het uit de waterbodem vrijkomen fosfor. 


\section{Vergelijking tussen aangeleverde projecten en de blauwdruk voor een icoonproject}

De 37 aangeleverde projecten zijn onder te verdelen in vier verschillende projecttypen (Tabel 5.1):

1. Instrumenten t.b.v. diagnose knelpunten en voorspellen problemen. Hierbinnen vallen het ontwikkelen of uitvoeren van systeemanalyses, voorspellingsmodellen enzovoorts;

2. Uitvoering van maatregelen t.b.v. kwaliteitsverbetering. Projecten waarbij het uitvoeren van maatregelen of maatregelpakketten centraal staan, vaak zijn hierbij ook 'nieuwe' technieken toegepast;

3. Monitoring van de effectiviteit van maatregelen. Monitoring van het doelbereik van uitgevoerde maatregelen, zowel met gevestigde als met 'nieuwe' technieken door het waterschap of door derden (burgers, aangelanden);

4. Creëren van draagvlak. Projecten waarbij bewustwording, betrokkenheid creëren van aangelanden/burgers, samenwerking met andere partijen (industrie) e.d. centraal staan, met als doel zo de waterkwaliteit te verbeteren, waterverbruik onder de aandacht te brengen of producten te verwaarden om zo projecten te financieren.

Uitvoerings- en monitoringsprojecten vormden de meerderheid van de aangeleverde projecten. Diagnostische projecten (systeemanalyses of experimenten om knelpunten te diagnosticeren) en projecten gericht op het creëren van draagvlak (samenwerking en de ontwikkeling van een businesscase) zijn minder vaak aangeleverd. Voor laag Nederland zijn relatief vaak projecten om blauwalgenbloei aan te pakken aangeleverd, waarbij de oplossingen om dit probleem aan te pakken varieerden van puur technologisch tot een integrale aanpak van de waterkwaliteitsproblematiek. Verder zijn maatregelen ten behoeve van de visstand ook vaak opgevoerd, waarbij de nadruk lag op vismigratie. Een aantal waterschappen op de hogere zandgronden heeft uitvoeringsprojecten ingebracht waarbij schaal van uitvoering en duurzaamheid een rol spelen. Hierbij werd gekozen voor een beekdalbrede benadering (waarbij niet alleen naar de beek gekeken wordt, maar ook naar het aanliggende beekdal omdat deze onlosmakelijk met elkaar verbonden zijn) en/of 'Bouwen-met-Natuur' maatregelen (natuurlijke processen gebruiken/in gang zetten/ruimte geven om herstel te bewerkstelligen, waarbij minder vervolgmaatregelen nodig zijn dan gewoonlijk, m.a.w. wat duurzamer is dan klassieke maatregelen). Andere benoemde aspecten zijn monitoring om bij te sturen bij ingrepen indien noodzakelijk en schaalvergroting om de effectiviteit te verhogen.

Wanneer de 9 bouwstenen voor een icoonproject werden vergeleken met de onderdelen van de voorbeeldprojecten bleek dat alle bouwstenen aanwezig waren in één of meerdere projecten (Tabel 5.2). Echter, geen enkel project bevatte alle bouwstenen; de meeste projecten bevatte er maar 1 of 2 . Het hoogst scorende project was het beekherstelproject Synergieproject Impuls Hierdense beek ( 5 bouwstenen) aangeleverd door waterschap Vallei en Veluwe. Wat er vooral in dit project mist ten opzichte van de complete blauwdruk voor een icoonproject is een systeem- en knelpuntenanalyse voor het stroomgebied. Goed scorende bouwstenen zijn effectiviteit van de maatregelkeuze en het volgen van de effecten via monitoring (effectbepaling). Systeemanalyses en knelpuntenanalyses komen vooral in isolatie voor, dus als project op zich en nog niet gekoppeld aan een herstelproject. Hetzelfde geldt voor projecten gericht op het creëren van maatschappelijk of financieel draagvlak (business cases). 
Tabel 5.1: Overzicht van de aangeleverde projecten, onderverdeeld naar projecttype.

\begin{tabular}{|c|c|c|c|c|c|}
\hline \multirow[b]{2}{*}{$\begin{array}{l}\frac{1}{0} \\
\frac{1}{d} \\
d \\
\frac{0}{0} \\
0\end{array}$} & \multirow[t]{2}{*}{ Projectnaam } & \multicolumn{4}{|c|}{ Projecttype } \\
\hline & & 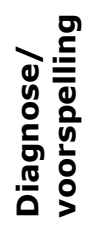 & 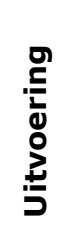 & 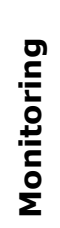 & 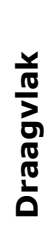 \\
\hline \multirow[t]{7}{*}{ HHNK } & Watersysteemanalyses & 1 & & & \\
\hline & Samenwerking bodem en water & & & & 1 \\
\hline & Citizen Science monitoring waterkwaliteit & & & 1 & 1 \\
\hline & Monitoring vismigratie Noordzeekanaalgebied & & & 1 & \\
\hline & EOMORES-project Algenradar in 't Twiske & 1 & & & \\
\hline & Inzet onderwaterdrone & & & 1 & \\
\hline & Toepassing eDNA voedselwebanalyses & & & 1 & \\
\hline \multirow[t]{4}{*}{ WHD } & De Blauwe Verbinding & & 1 & & \\
\hline & Vegetatie-onderzoek Goeree-Overflakkee & 1 & & 1 & \\
\hline & Oostvoornse Meer & 1 & & 1 & \\
\hline & WasteShark & & & & 1 \\
\hline WZL & Robuuste herinrichting Hoge Dwarsvaart & & 1 & & \\
\hline \multirow[t]{2}{*}{ HR } & Reeuwijkse plassen & & & 1 & \\
\hline & Een betere waterkwaliteit in de bollenteelt door ijzerzand & & 1 & & \\
\hline \multirow[t]{3}{*}{ WVS } & Beneden Regge & & 1 & & \\
\hline & Hagmolenbeek (project Twickel) & & 1 & & \\
\hline & Deurningerbeek & & 1 & & \\
\hline \multirow[t]{6}{*}{ HSR } & Vismigratie Rijn-west & & & 1 & \\
\hline & Modelonderzoek vispassage & 1 & & & \\
\hline & Nevengeul Kromme Rijn bij Odijk & & 1 & & \\
\hline & Waterkwaliteitsmodule Tygron Engine & 1 & & & \\
\hline & Aquafarm & & 1 & 1 & 1 \\
\hline & De boerensloot leeft & & & 1 & 1 \\
\hline \multirow[t]{3}{*}{ WD } & Herkomst nutriënten Reuseldal & 1 & & & \\
\hline & Dood hout inbreng Tongelreep (en/of Beekloop) & & 1 & 1 & \\
\hline & Inventarisatie macrofyten overige wateren t.b.v. waterkwaliteitsspoor & & & 1 & \\
\hline \multirow[t]{2}{*}{ WAGV } & De Vecht & & 1 & & \\
\hline & $\begin{array}{l}\text { Oxidatie van het hypolimnion als defosfateringssysteem in de } \\
\text { Ouderkerkerplas }\end{array}$ & & 1 & 1 & 1 \\
\hline \multirow[t]{3}{*}{ WVV } & Synergieproject Impuls Hierdense Beek & & 1 & 1 & \\
\hline & Aanleg beekbegeleidende zone Modderbeek & & 1 & & \\
\hline & $\begin{array}{l}\text { Gecombineerd ecologische en cultuurhistorisch herstel sprengenstelsel } \\
\text { Vaassense beken }\end{array}$ & & 1 & & 1 \\
\hline \multirow[t]{3}{*}{ WSS } & Vispassages tussen binnen- en buitenwateren & & 1 & & \\
\hline & Natuurvriendelijke oevers & & 1 & & \\
\hline & Toekomstige aanpak & 1 & & & \\
\hline
\end{tabular}




\begin{tabular}{|c|c|c|c|c|c|}
\hline \multirow[b]{2}{*}{ 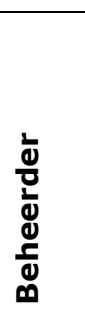 } & \multirow[t]{2}{*}{ Projectnaam } & \multicolumn{4}{|c|}{ Projecttype } \\
\hline & & 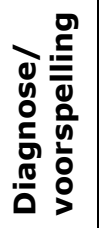 & 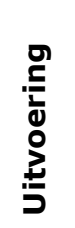 & 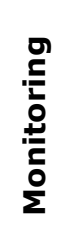 & $\begin{array}{l}\frac{y}{0} \\
\frac{\pi}{3} \\
\frac{0}{\pi} \\
\frac{\pi}{0} \\
\text { o. }\end{array}$ \\
\hline \multirow[t]{4}{*}{ WBD } & Boven Donge - meander Leijkant & & 1 & & \\
\hline & Binnenschelde - snoekpaaigebied & & 1 & 1 & \\
\hline & Verbetering waterkwaliteit stadswater Groote Melanen & 1 & 1 & 1 & \\
\hline & Verbetering waterkwaliteit zwemplas De Kuil & 1 & 1 & 1 & \\
\hline \multicolumn{2}{|c|}{ Totaal aantal projecten } & 10 & 20 & 17 & 7 \\
\hline
\end{tabular}


Tabel 5.2: Het aantal bouwstenen dat de aangeleverde projecten bevat. De bouwstenen worden toegelicht in hoofdstuk 3.

\begin{tabular}{|c|c|c|c|c|c|c|c|c|c|c|c|}
\hline \multirow[b]{2}{*}{ 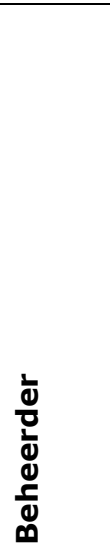 } & \multirow[t]{2}{*}{ Projectnaam } & \multicolumn{10}{|c|}{$\begin{array}{l}\text { Bouwstenen die onderdeel uitmaken van het } \\
\text { project }\end{array}$} \\
\hline & & 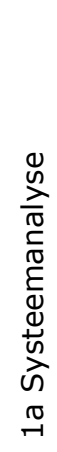 & 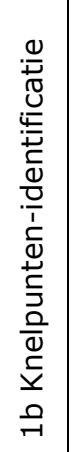 & 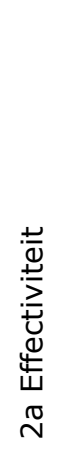 & 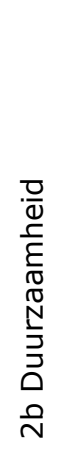 & 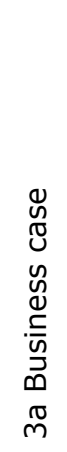 & 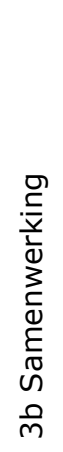 & 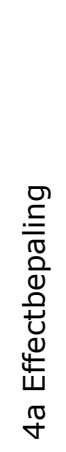 & 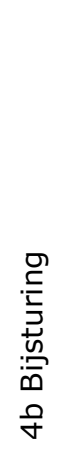 & 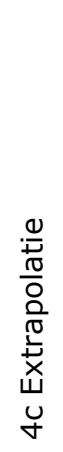 & 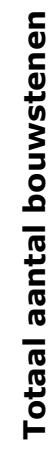 \\
\hline \multirow[t]{7}{*}{ HHNK } & Watersysteemanalyses & 1 & & & & & & & & & 1 \\
\hline & Samenwerking bodem en water & & & & & & 1 & & & & 1 \\
\hline & Citizen Science monitoring waterkwaliteit & & & & & & 1 & 1 & & & 2 \\
\hline & Monitoring vismigratie Noordzeekanaalgebied & & & & & & & 1 & & & 1 \\
\hline & EOMORES-project Algenradar in 't Twiske & 1 & 1 & & & & & & & & 2 \\
\hline & Inzet onderwaterdrone & & & & & & & 1 & & & 1 \\
\hline & Toepassing eDNA voedselwebanalyses voor toestandsbepaling en systeembegrip & & & & & & & 1 & & & 1 \\
\hline \multirow[t]{4}{*}{ WHD } & De Blauwe Verbinding & & & 1 & & & & & & & 1 \\
\hline & Vegetatie-onderzoek Goeree-Overflakkee & & 1 & & & & & 1 & & & 2 \\
\hline & Oostvoornse Meer & & 1 & & & & & 1 & & & 2 \\
\hline & WasteShark & & & & & 1 & & & & & 1 \\
\hline WZL & Robuuste herinrichting Hoge Dwarsvaart & & & 1 & & & & & & & 1 \\
\hline $\mathrm{HR}$ & Reeuwijkse plassen & & & & & & & 1 & & & 1 \\
\hline
\end{tabular}




\begin{tabular}{|c|c|c|c|c|c|c|c|c|c|c|c|}
\hline \multirow{3}{*}{$\begin{array}{l}\frac{1}{0} \\
\frac{0}{2} \\
\mathbb{d} \\
\frac{c}{0} \\
\text { D }\end{array}$} & \multirow[t]{2}{*}{ Projectnaam } & \multicolumn{10}{|c|}{$\begin{array}{l}\text { Bouwstenen die onderdeel uitmaken van het } \\
\text { project }\end{array}$} \\
\hline & & 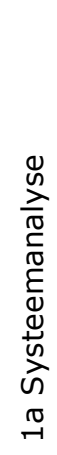 & 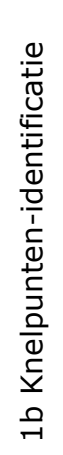 & 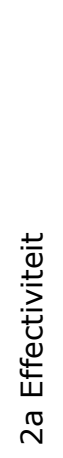 & 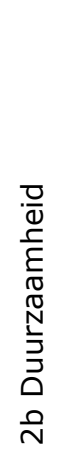 & 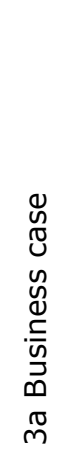 & 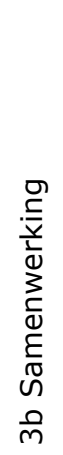 & 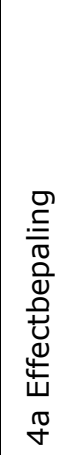 & 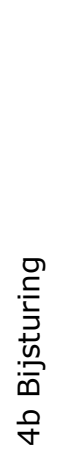 & 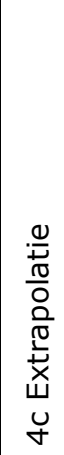 & 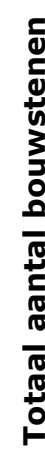 \\
\hline & Een betere waterkwaliteit in de bollenteelt door ijzerzand & & & & & 1 & & 1 & & & 2 \\
\hline \multirow[t]{3}{*}{ WVS } & Beneden Regge & & & 1 & 1 & & & 1 & & & 3 \\
\hline & Hagmolenbeek (project Twickel) & & & 1 & 1 & & & 1 & & & 3 \\
\hline & Deurningerbeek & & & 1 & 1 & & & 1 & & & 3 \\
\hline \multirow[t]{6}{*}{ HSR } & Vismigratie Rijn-west & & & & & & & 1 & & & $\mathbf{1}$ \\
\hline & Modelonderzoek vispassage & & & 1 & & & & 1 & & & 2 \\
\hline & Nevengeul Kromme Rijn bij Odijk & & & & & & & 1 & & & $\mathbf{1}$ \\
\hline & Waterkwaliteitsmodule Tygron Engine & 1 & & & & & & & & & $\mathbf{1}$ \\
\hline & Aquafarm & & & 1 & & 1 & 1 & & & & 3 \\
\hline & De boerensloot leeft & & & & & & 1 & 1 & & & 2 \\
\hline \multirow[t]{4}{*}{ WD } & Herkomst nutriënten Reuseldal & 1 & 1 & & & & & & & & 2 \\
\hline & $\begin{array}{l}\text { Kleinschalige maatregelen, resultaten tongelreep, dood hout in de beek Dood hout inbreng } \\
\text { Tongelreep (en/of Beekloop) }\end{array}$ & & & 1 & & & & 1 & & 1 & 3 \\
\hline & $\begin{array}{l}\text { Doelen overig; macrofyten inventarisatie Veldmethode KRW-beoordeling macrofyten overige } \\
\text { wateren t.b.v. waterkwaliteitsspoor }\end{array}$ & & & & & & & 1 & & & $\mathbf{1}$ \\
\hline & De Vecht & & & 1 & & & & & & & 1 \\
\hline
\end{tabular}




\begin{tabular}{|c|c|c|c|c|c|c|c|c|c|c|c|}
\hline \multirow{3}{*}{ 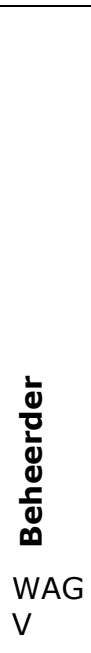 } & \multirow[t]{2}{*}{ Projectnaam } & \multicolumn{10}{|c|}{$\begin{array}{l}\text { Bouwstenen die onderdeel uitmaken van het } \\
\text { project }\end{array}$} \\
\hline & & 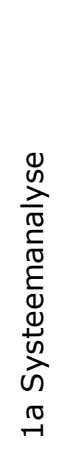 & 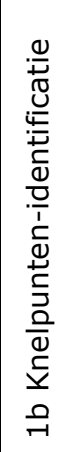 & 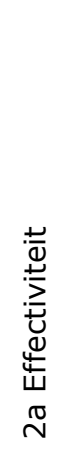 & 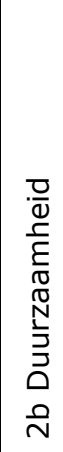 & 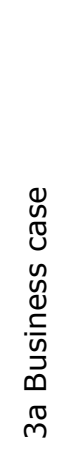 & 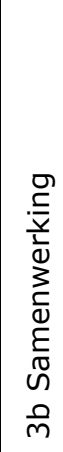 & 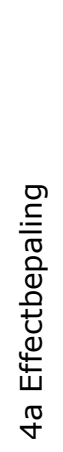 & 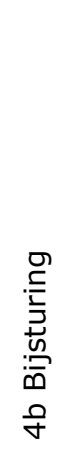 & 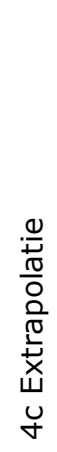 & 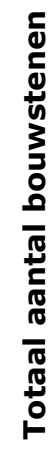 \\
\hline & Oxidatie van het hypolimnion als defosfateringssysteem in de Ouderkerkerplas & & & & & 1 & & 1 & 1 & & 3 \\
\hline \multirow[t]{3}{*}{ WVV } & Synergieproject Impuls Hierdense Beek & & & 1 & 1 & & 1 & 1 & 1 & & 5 \\
\hline & Aanleg beekbegeleidende zone Modderbeek & & & 1 & 1 & & & & & & 2 \\
\hline & Gecombineerd ecologische en cultuurhistorisch herstel sprengenstelsel Vaassense beken & & & 1 & & & 1 & & & & 2 \\
\hline \multirow[t]{3}{*}{ WSS } & Vispassages tussen binnen- en buitenwateren & & & 1 & & & & & & & 1 \\
\hline & Natuurvriendelijke oevers & & & & & & & & & & $\mathbf{0}$ \\
\hline & Toekomstige aanpak & & 1 & & & & & & & & 1 \\
\hline \multirow[t]{4}{*}{ WBD } & Boven Donge - meander Leijkant & & & 1 & & & & 1 & & & 2 \\
\hline & Binnenschelde - snoekpaaigebied & & & 1 & & & & 1 & & & 2 \\
\hline & Verbetering waterkwaliteit stadswater Groote Melanen & 1 & 1 & 1 & & & & 1 & & & 4 \\
\hline & Verbetering waterkwaliteit zwemplas De Kuil & 1 & 1 & 1 & & & & 1 & & & 4 \\
\hline \multicolumn{2}{|c|}{ Totaal aantal projecten } & 6 & 7 & 17 & 5 & 4 & 6 & 23 & 2 & 1 & \\
\hline
\end{tabular}




\section{Conclusies en aanbevelingen}

Er zijn in totaal 9 bouwstenen gedefinieerd voor het uitvoeren van een icoonproject. Er is onderscheid gemaakt in vier projectfasen. Een icoonproject begint bij het formuleren van een concreet doel (fase 1). Hiervoor is systeembegrip nodig. Om dit te krijgen moet een systeemanalyse (bouwsteen 1a) worden uitgevoerd: wat zijn de relevante systeemkenmerken en processen (sleutelfactoren) en wat is de toestand en werking? Dit wordt gevolgd door de identificatie van knelpunten (bouwsteen 1b). Het in beeld krijgen van de schaal en effecten van de knelpunten is essentieel. Knelpunten zorgen er namelijk voor dat de huidige ecologische toestand niet overeenkomt met de gewenste ecologische toestand. Deze moeten worden aangepakt.

Om de knelpunten te kunnen aanpakken moeten haalbare oplossingen worden bedacht: de keuze van maatregelen (fase 2) passend bij de randvoorwaarden die horen bij een specifiek waterlichaam. Voor een optimaal resultaat moeten maatregelen passen op de complete set van knelpunten en leiden tot het projectdoel met een zo laag mogelijke inspanning/kosten, oftewel er moet gekozen worden op basis van effectiviteit (bouwsteen 2a). In bijlage 2 is per type overig water een overzicht gemaakt van mogelijke maatregelen, van kleine snel te realiseren ingrepen tot grootschalige veranderingen in de inrichting of hydrologie van een gebied, die pas op de langere termijn en met grotere ingrepen realiseerbaar zal zijn. De maatregelen zijn een opsomming van alle maatregelen die de afgelopen decennia in Nederland zijn toegepast (Nijboer 2000; Bleeker \& Verdonschot, 2007; Peeters et al., 2014; Verdonschot et al., 2016). Echter, hoe, waar en wanneer (combinaties van) maatregelen effectief kunnen worden ingezet, is sterk afhankelijk van de lokale omstandigheden en daarmee in de meeste gevallen waterlichaam-specifiek.

Belangrijk bij de keuze van maatregelen is dat deze duurzaam (bouwsteen 2b) zijn. Dit wil zeggen dat er een zo gering mogelijke verstoring van het systeem optreedt en het systeem in een toestand gebracht wordt waarin amper moet worden ingegrepen. Een beekdalbrede benadering (waarbij niet alleen naar de beek gekeken wordt, maar ook naar het aanliggende beekdal omdat deze onlosmakelijk met elkaar verbonden zijn) en/of 'Bouwen-met-Natuur' maatregelen (natuurlijke processen gebruiken/in gang zetten/ruimte geven om herstel te bewerkstelligen, waarbij minder vervolgmaatregelen nodig zijn dan gewoonlijk, m.a.w. wat duurzamer is dan klassieke maatregelen) zijn hier goede voorbeelden van.

Om een project met daarbinnen de juiste maatregelen daadwerkelijk te kunnen uitvoeren, is het creëren van draagvlak (fase 3) belangrijk. Draagvlak kan worden gecreëerd op financieel vlak, bijvoorbeeld via meekoppel-kansen en het ontwikkelen van business cases (bouwsteen 3a), om de kosten die gepaard gaan met grootschalige ingrepen te reduceren. Vaststellen van ecosysteemdiensten die watersystemen bieden en het verwaarden hiervan zou hierbij als ingang kunnen fungeren, net zoals de circulariteitsgedachte (gesloten kringlopen). Cruciaal om tot uitvoering van een duurzame en grootschalige brongerichte aanpak van knelpunten te komen is samenwerking (bouwsteen 3b) met belanghebbenden in andere domeinen, zoals agrarische sector en aanwonenden, cruciaal, beleidsmatig ondersteund via wet- en regelgeving. Zonder medewerking vanuit deze domeinen is het niet mogelijk te komen tot een optimale effectiviteit van herstelmaatregelen. Ook interne samenwerking draagt bij aan het verhogen van de slagingskans en effectiviteit van projecten.

Is er een uitvoeringsplan, dan is het belangrijk te starten met monitoring (fase 4), nog voor de maatregelen daadwerkelijk genomen worden. Monitoring is essentieel om vast te stellen in hoeverre de gestelde doelen worden gehaald, oftewel voor de effectbepaling (bouwsteen 4a). Daarnaast kan het de effectiviteit verhogen door tijdens en na de uitvoering te meten, omdat er dan bijsturing

(bouwsteen 4b) kan plaatsvinden mochten processen anders verlopen dan verwacht. Ecosystemen zijn 
complex en er zijn in zowel de biologische, hydrologische en morfologische processen diverse kennishiaten. Het is daarom niet mogelijk volledig vooraf te voorzien hoe een ecosysteem reageert. Er zou daarom al in de planningsfase moeten worden ingezet op adaptief beheer, zodat bijsturing en nazorg binnen het project passen. Tenslotte is monitoring belangrijk om te leren van het project, zodat de opgedane ervaringen toegepast en geoptimaliseerd kunnen worden in toekomstige projecten. Dit maakt extrapolatie (bouwsteen 4c) in binnen- en buitenland mogelijk.

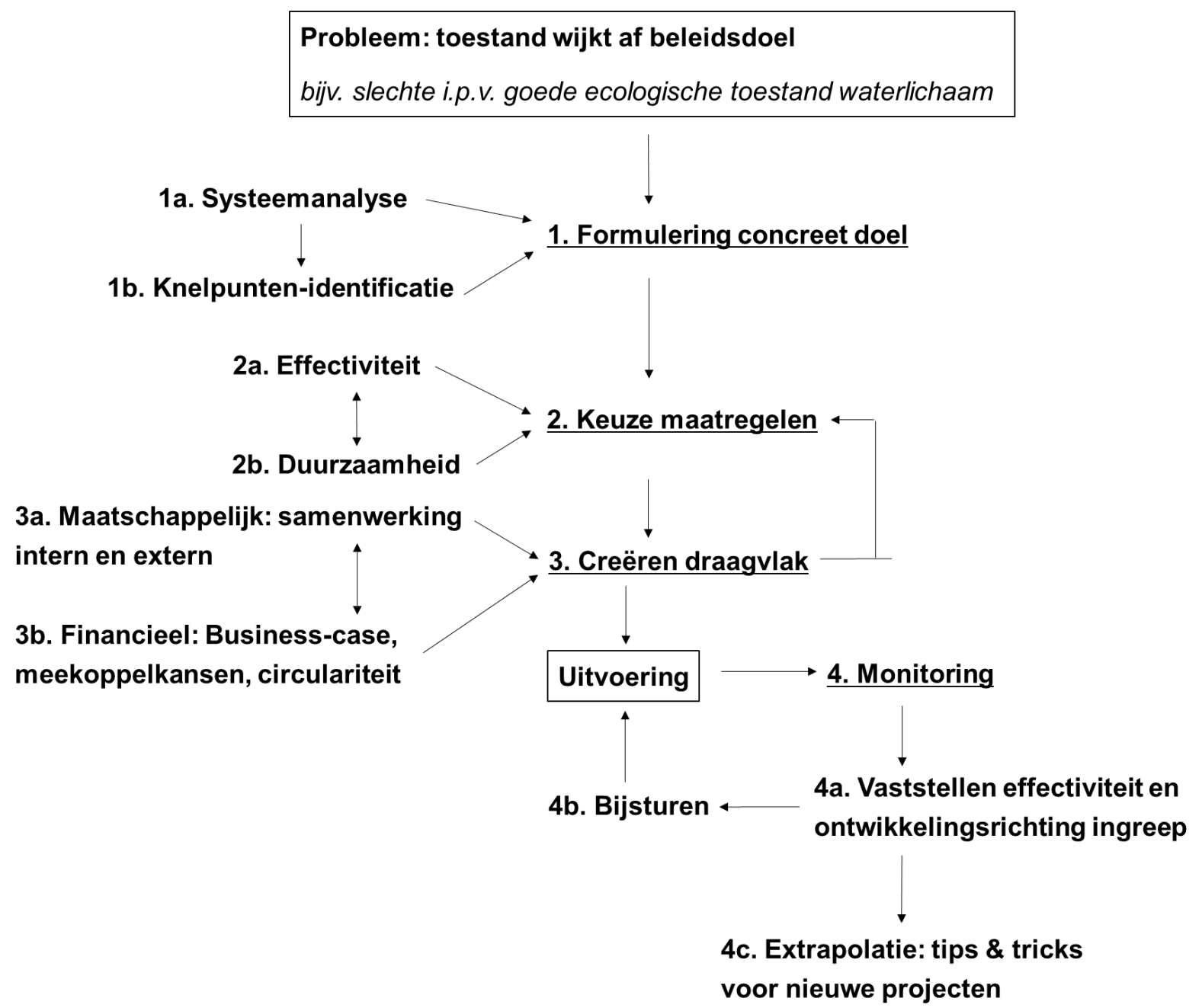

Figuur 6.1: Diagram met de samenhang tussen de bouwstenen van een icoonproject.

Op basis van de aangeleverde projecten kan worden geconcludeerd dat alle bouwstenen op dit moment aanwezig zijn, maar dat er sprake is van sterke fragmentatie. Individuele projecten bevatten telkens enkele bouwstenen, bijvoorbeeld sterke inzet op systeemanalyses, draagvlak, business cases of het vaststellen van de effectiviteit. Echter is een project dat de complete blauwdruk van een icoonproject volgt niet aangeleverd. Juist het doorlopen van de volledige cyclus zou het succes van projecten kunnen vergroten (Figuur 6.1). Werken op de juiste schaal is in onze ogen hierbij essentieel. Er worden gewoonlijk drie schaalniveaus van klein naar groot onderscheiden waar maatregelen kunnen worden ingezet: habitat, traject en beekdal/stroomgebied. Effectieve maatregelpakketten omvatten alle drie de schaalniveaus. De veel ingezette habitatmaatregelen hebben vooral een relatie met het beheer en 
onderhoud van de watergang en zijn in isolatie niet voldoende om grootschalige verbeteringen te bewerkstelligen. De hogere schaalniveaus omvatten vooral landschappelijke inrichtingsmaatregelen. De mogelijkheden voor deze groep zijn sterk contextafhankelijk en door hun ruimtegebruik vragen deze maatregelen een grotere inspanning: er kan gesteld worden dat alle bouwstenen moeten worden aangesproken om tot het gewenste resultaat te komen. Er is meer inspanning nodig om tot resultaten te komen, maar de effectiviteit van dit type maatregelen is er dan ook naar. In de toekomst zou dan ook meer moeten worden gestreefd naar ingrijpen op dit schaalniveau: effectief, brongericht, duurzaam (Bouwen-met-Natuur) en extrapoleerbaar. De beekdalbrede benadering zoals deze op steeds meer plekken op de hogere zandgronden wordt ingezet is hier een mooi voorbeeld van (Figuur 6.2).

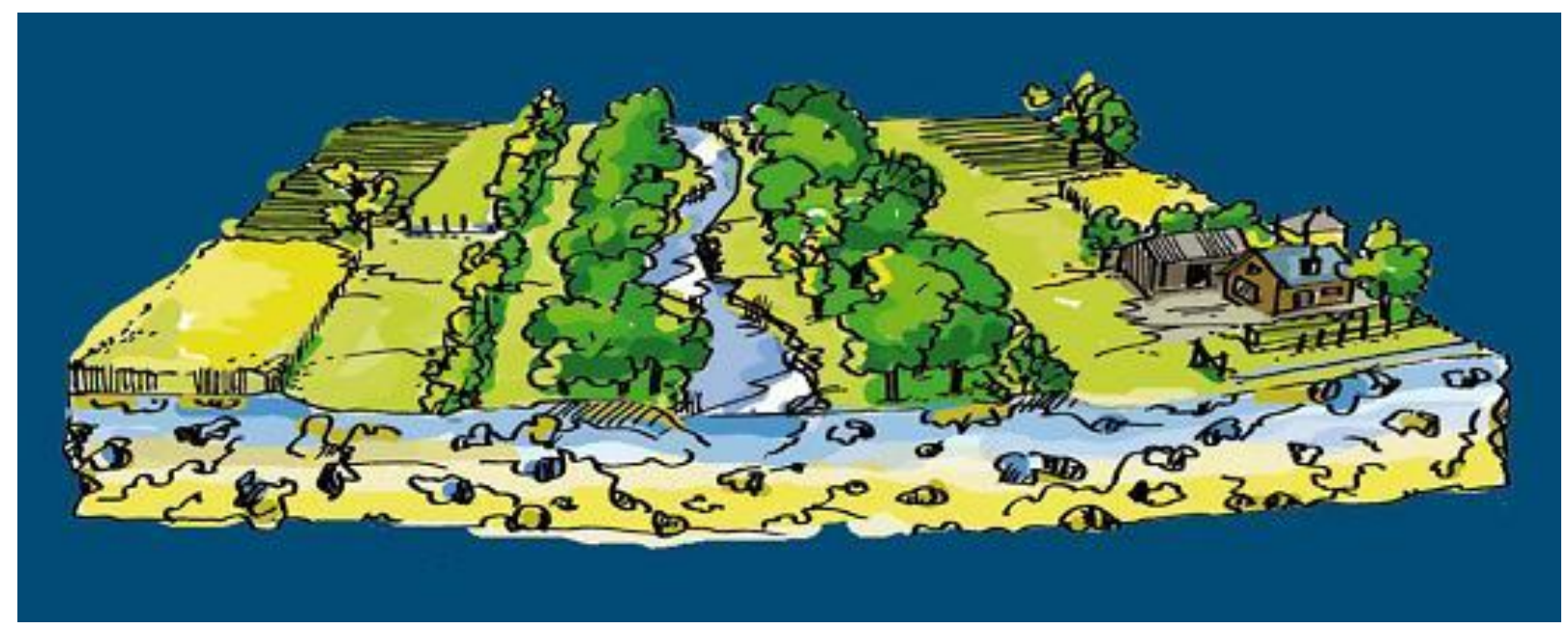

Figuur 6.2 Toekomstsbeeld beekdalbreed herstel, waarin via grootschalige effectieve en duurzame Bouwen-met-Natuur-maatregelen een beeksysteem is ontstaan met gezond water voor de natuur en de landbouw dat robuust is om veranderingen, zoals in het klimaat, te mitigeren. 


\section{Literatuur}

Bleeker, M., Verdonschot, P.F.M. (2007) Een expertsysteem voor de keuze van hydrologische maatregelen V. Maatregelenwijzer Waterbeheer. Alterra rapport 1521, Alterra, Wageningen.

Feld, C. K., Birk, S., Bradley, D. C., Hering, D., Kail, J., Marzin, A., Melcher, A., Nemitz, D., Pedersen, M.L, Pletterbauer, F., Pont, D., Verdonschot, P.F.M., Friberg, N. (2011) From natural to degraded rivers and back again. A test of restoration ecology theory and practice. Advances in Ecological Research 44: 119-209.

Nijboer, R.C. (2000) Natuurlijke levensgemeenschappen van de Nederlandse Binnenwateren, deel 6, Sloten. Achtergronddocument bij het 'Handboek Natuurdoeltypen in Nederland'. Expertisecentrum LNV, Rapport AS-06.

Peeters, E.T.H.M., Veraart, A.J., Verdonschot, R.C.M., van Zuidam, J.P., de Klein, J.J.M., Verdonschot, P.F.M. (2014) Sloten; ecologisch functioneren en beheer. KNNV Uitgeverij, Zeist.

Verdonschot, P., Verdonschot, R., Bauwens, J., Brugmans, B., Dees, A., Kits, M., Moeleker, M., Hoog, J. de, Scheepens, M., Barten, I., Coenen, D., Vught, A. van, Roovers, S. (2016) Kennisoverzicht kleinschalige maatregelen in Brabantse beken. STOWA rapport 2017-16, STOWA, Amersfoort.

Verdonschot, P.F.M. (red.) (1995) Beken stromen: Leidraad voor ecologisch beekherstel. STOWA rapport 95-03, STOWA, Utrecht. 


\section{Begrippenlijst}

Abiotisch: De fysische en chemische eigenschappen of condities die een ecosysteem kenmerken.

Benthisch: Op/in de bodem levend.

Connectiviteit: Hoeveelheid verbindingen tussen waterlichamen.

Dispersie: Verplaatsing van individuen van een soort door middel van vliegen, zwemmen of meeliften met andere dieren, vaak ongericht en eenmalig.

Habitatheterogeniteit: Mozaïek van verschillende habitats voor organismen. Dit patroon is het resultaat van bijvoorbeeld lokale verschillen in milieuomstandigheden.

Indicator: Een soort die informatie geeft over de staat waarin het ecosysteem verkeert.

Kolonisatie: Het zich vestigen van een soort op een plek waar deze niet (meer) voorkwam.

KaderRichtlijn Water: In de Europese KaderRichtlijn Water (KRW) is het beleid voor de beoordeling van de kwaliteit van het oppervlakte- en grondwater in Europa vastgelegd.

Levensgemeenschap: Een groep samen voorkomende soorten. Meestal treden er interacties op tussen de individuele soorten.

Macrofauna: Alle in het water levende dieren die met het blote oog waarneembaar zijn, grofweg groter of gelijk aan een millimeter.

Macrofyten: Waterplanten

Habitat: Leefplek van een organisme. Afhankelijk van de grootte van het organisme kan dit op een zeer klein schaalniveau zijn, bijvoorbeeld een blad van een waterplant, tot op een groot schaalniveau, zoals een plas.

Nutriënten: Voedingsstoffen, zoals nitraat en fosfaat.

Overgedimensioneerd: Dat deel van de dwarsdoorsnede van een watergang dat niet nodig is om de maximale waterafvoer te garanderen.

Pioniersituatie: Waterlichaam met een kaal gemaakt bodemsubstraat. Hierop vestigen zich pioniers, bijvoorbeeld kranswieren.

Referentie: Een waterlichaam dat qua fysische, chemische en biologische omstandigheden de natuurlijke omstandigheden omvat of zo goed mogelijk benadert.

Schonen: Het periodiek verwijderen van watervegetatie om belemmering van de doorstroming en verlanding te voorkomen.

Stratificatie: Gelaagdheid van het water in de waterkolom door temperatuurverschillen. 


\title{
Bijlage 1 Detailinformatie icoonprojecten
}

\author{
Projecten hoogheemraadschap Hollands Noorderkwartier
}

Aangeleverd door Sandra Roodzand.

\section{Watersysteemanalyses}

Voor al onze KRW-waterlichamen wordt op dit moment een uitgebreide watersysteemanalyse gemaakt. Aan de hand van de ecologische sleutelfactoren wordt een oordeel geveld over de huidige status van een waterlichaam en beoordeeld welke maatregelen tot een mogelijke verbetering kunnen leiden. Uiteindelijke doel is om realistische KRW-doelen te formuleren (doelen op maat). Om tot realistische doelen te komen, is een gedegen analyse nodig van de knelpunten en mogelijke maatregelen in het waterlichaam.

\section{Samenwerking bodem en water}

Samenwerking bodem en water is een samenwerkingsproject van de waterbeheerders, LTO-Noord, agrarische collectieven en de provincie Noord-Holland, waarbij de verschillende agrarische sectoren gestimuleerd worden om maatregelen te treffen om emissies naar oppervlaktewater van nutriënten en gewasbeschermingsmiddelen naar oppervlaktewater te verminderen en om zoetwatermaatregelen te treffen die zuinig gebruik van water bevorderen. Voor dit doel is het Landbouwportaal Noord-Holland ontwikkeld, (https://www.landbouwportaalnoordholland.nl). Hierop kunnen agrarische ondernemers zich oriënteren op mogelijke maatregelen die ze op hun terrein kunnen nemen. Ook kunnen ze een aanvraag doen voor een coach, die helpt bij de selectie van maatregelen. Voor bepaalde maatregelen kunnen ze via het portaal subsidie aanvragen. De maatregelen zijn ingedeeld in vijf modules:

1. Erfafspoeling;

2. Duurzaam bodemgebruik;

3. Gewasbeschermingsmiddelen;

4. Voldoende zoet water;

5. Perceel- en oeverinrichting \& beheer.

\section{Citizen Science monitoring waterkwaliteit.}

Monitoring van de flora en fauna van onze natuurvriendelijke oevers door vrijwilligers (vanaf 2014, o.l.v. Landschap Noord-Holland). Sinds dit jaar gaat dit via een zogenaamde Waterbox. In de Waterbox zit een vijftal experimenten om de waterkwaliteit te meten. Meetresultaten kunnen zij invoeren op https://hetschonewaterexperiment.nl/hhnk/. Naast de natuurvriendelijke oevers kunnen de vrijwilligers deze experimenten ook uitvoeren in andere wateren, zoals hun eigen de sloot of vijver. Doel van dit project is om het draagvlak te vergroten en het waterbewustzijn van de vrijwilligers te vergroten. Synchroon aan dit project loopt een KRW-monitoringsprogramma waarbij dezelfde natuurvriendelijke oever-locaties worden bemeten. Deze monitoring loopt vanaf 2014 tot het heden.

\section{Monitoring vismigratie Noordzeekanaalgebied}

Monitoring vismigratie Noordzeekanaalgebied is een samenwerking tussen alle waterbeheerders in en rond het Noordzeekanaalgebied. Vissen worden gemerkt met een VIE-tag, zodat ze met een speciale UVlamp oplichten. Hierdoor kunnen we zien hoe ze zich verspreiden door het gebied. 


\section{EOMORES-project Algenradar in 't Twiske}

't Twiske is een recreatiegebied, Natura2000-gebied en KRW-waterlichaam met negen verschillende zwemstrandjes. Ontwikkeling van blauwalgen is hier een jaarlijks terugkerend probleem. Deltares is voor ons bezig om een voorspellingsmodel op te zetten welke aan de hand van waterkwaliteitsmetingen en weersverwachtingen een voorspelling kan doen van de te verwachten blauwalgconcentratie. Dit model wordt ondersteund met satellietbeelden. Doel van het model is de ontwikkeling van blauwalgen tijdig te kunnen voorspellen en de zwemmers te informeren en adviseren om bijvoorbeeld bepaalde zwemstrandjes te mijden (i.p.v. achteraf te waarschuwen of een negatief zwemadvies af te geven). Dit project loopt in de periode 2017-2018.

\section{Inzet onderwaterdrone}

Ten behoeve van de waterkwaliteitsmetingen voor de Algenradar wordt er in 't Twiske geëxperimenteerd met een onderwaterdrone. Deze onderwaterdrone doet gebiedsdekkende waterkwaliteitsmetingen. Resultaten hiervan worden gebruikt in het Algenradar-model. Dit onderzoek vindt in 2018 plaats.

\section{Toepassing eDNA voedselwebanalyses voor toestandsbepaling en systeembegrip}

Toepassing eDNA voedselwebanalyses om toestandsbepalingen te kunnen doen en een beter systeembegrip te krijgen. Dit project betreft een nieuwe toepassing van eDNA, waarmee met zo min mogelijk inspanning een zo groot mogelijk deel van het voedselweb in beeld gebracht kan worden. De toepassing heet de eDNA voedselwebanalyse. Concreet kunnen we met slechts één watermonster een integraal beeld van het leven onder water krijgen. We kijken hierbij o.a. naar bacteriën, zoöplankton, vissen, (blauw)algen, tweekleppigen enzovoorts. Dit draagt bij aan een goede duiding van de ecologische toestand en aan een beter begrip van het ecologisch functioneren. Deze vorm van monitoring is goedkoper, sneller, robuuster en veel completer dan conventionele monitoring. Het doel van dit project is om ervaring met de eDNA voedselwebanalyse op te doen en op basis hiervan belangrijke belemmeringen voor grootschalige toepassing van de eDNA voedselwebanalyse weg te nemen. Dit onderzoek loopt in de periode 2018-2019 en zal ook in 't Twiske plaatsvinden. 


\section{Projecten waterschap Hollandse Delta}

Aangeleverd door Hanneke Maandag en Diana Beltgens.

\section{De Blauwe Verbinding}

\section{Setting}

De Blauwe Verbinding verbindt verschillende zwemplassen en het Zuiderpark in Rotterdam en verbindt hiermee de Oude Maas en de Nieuwe Waterweg.

\section{Doel}

De watervoorziening van zuidelijk Rotterdam is voor een groot deel afhankelijk van de inlaten van uit de Nieuwe Waterweg. De Nieuwe Waterweg wordt zout bij een lage rivierafvoer. Door dat de Oude Maas dit probleem (nog) niet heeft, is bedacht zoet en relatief schoon water vanuit de Oude Maas naar het noorden te leiden. Tevens was er behoefte aan een recreatieve verbinding tussen Rotterdam en de Oude Maas.

\section{Streefbeeld}

Een mooie watergang geschikt voor kano's en een verbinding om schoon water naar het Zuiderpark en de omliggende woonwijken te leiden. Ook de zwemwateren in het Zuidelijk Randpark kunnen door de aanvoer van schoonwater beter worden ververst, zodat de kans op blauwalgen afneemt. Het Zuiderpark is ook een zwemwater geworden en water uit de Nieuwe Waterweg hoeft niet meer te worden ingelaten.

\section{Aanpak}

Omdat de Blauwe Verbinding zeer veel infrastructurele knelpunten moest kruisen, heeft het project tien jaar geduurd. Er is een bevaarbare route ontstaan onder de A15 door en het is nu mogelijk om vanaf het Zuiderpark naar de Oude Maas te kanoën.

\section{Resultaten}

Omdat het project pas in het voorjaar van 2018 is opgeleverd, is het nog niet duidelijk welke resultaten behaald zijn. Wel is duidelijk dat ondanks een verbeterde waterkwaliteit er nog steeds problemen met blauwalgen zijn in het Zuiderpark zijn en dat er in de droge zomer van 2018 nog steeds brak water moest worden ingelaten. Evaluatie en uitbreiding van de waterinfrastructuur moeten deze problemen in de nabije toekomst oplossen.

\section{Vegetatie onderzoek Goeree-Overflakkee}

\section{Setting}

Op Goeree-Overflakkee liggen verschillende waterlichamen. De waterlichamen zijn alle kunstmatig en worden beïnvloed door zout water. Enkele waterlichamen zijn getypeerd als zwak brak (type M30), andere als een regionaal kanaal.

\section{Doel}

Bijna alle waterlichamen op Goeree-Overflakkee hebben het probleem dat er zeer weinig of geen bedekking is met ondergedoken waterplanten. De waterlichamen staan onder invloed van verschillende drukken, die mogelijk de ontwikkeling van ondergedoken vegetatie verhinderen. Dit zijn:

- Hoge troebelheid, 
- Zoet-zout-schommelingen die tegennatuurlijk zijn ('s winters zout, 's zomers zoet),

- Aanwezigheid van exoten: graskarpers en kreeften,

- Relatief hoge nutriëntengehalten.

Nu wordt onderzocht welke oorzaak of oorzaken er zijn die er voor zorgen dat de groei van ondergedoken waterplanten achterblijft.

\section{Streefbeeld}

Het streefbeeld is dat door inzicht in de oorzaken van het niet voorkomen van ondergedoken waterplanten gerichte maatregelen kunnen worden genomen om de waterplantengroei te bevorderen. Indien er geen maatregelen kunnen worden genomen, zal er voor de macrofyten-maatlat een lager doelbereik worden voorgesteld.

\section{Aanpak}

De effecten van hierboven genoemde mogelijke factoren zullen in zowel veld (in-situ) experimenten als in laboratoriumexperimenten worden onderzocht. In de veldexperimenten zal met behulp van exclosures worden onderzocht wat het effect van de factor vraat en/of opwoelen van de bodem op de ontwikkeling van de vegetatie is. Er zullen waterplanten worden aangeplant in de exclosures met en zonder speciale rekjes, waardoor er onderscheid kan worden gemaakt tussen het effect van vraat of opwoelen op de vegetatie. Daarnaast zal worden gekeken naar de spontane ontwikkeling van vegetatie in de kooien. De factor licht en algengroei zal in de exclosure-opzet worden meegenomen door in-situ metingen te doen naar doorzicht en lichtintensiteit. Door op iedere locatie bij de kooien ook een plek te creëren waardoor luwte ontstaat (bijv. door schermen haaks op de stroming te plaatsen) zal tevens worden gemonitord of dit leidt tot verbetering van het doorzicht en de lichtintensiteit. Het effect van zoutfluctuaties op de vegetatie zal worden onderzocht in een laboratoriumexperiment. Bovendien wordt de kiemkracht in de bodem (zaadbank) in een laboratoriumexperiment getest. Samengevat bestaat het onderzoek uit:

- Veldonderzoek (in-situ experimenten) effecten bodem op woelen en/of vraat m.b.v. exclosures,

- Monitoring bodemchemie en waterkwaliteit,

- Monitoring ontwikkeling waterplanten,

- Monitoring fauna via onderwatervideo,

- Laboratoriumexperiment effecten fluctuerende zoutgehalten op aquatische vegetatie,

- Laboratoriumexperiment kiemkracht waterbodems.

\section{Tijdslijn}

De experimenten vinden plaats tussen december 2017 en augustus 2018. De laboratoriumexperimenten zijn reeds afgerond.

\section{Resultaten}

De resultaten van de experimenten zijn nog niet bekend.

\section{Overlast benthische blauwalgen Oostvoornse Meer}

\section{Setting}

Het Oostvoornse Meer is een matig groot matig brak meer (M31). Het meer is geïsoleerd en kreeg tot 2008 alleen water door neerslag en afstromend duinwater. Doordat het water begon te verzoeten, ontstond de angst dat de kans op blauwalgenbloei in de zomer sterk zou toenemen. Het meer heeft zeer hoge fosfaatgehalten en zeer lage stikstofconcentraties. Het meer heeft belangrijke recreatieve functie met veel horeca. 


\section{Doel}

$\mathrm{Na}$ het inlaten van brak water vanuit het Havenkanaal begon het zoutgehalte weer te stijgen. Na een aantal jaar traden er grote problemen op met benthische blauwalgen (Oscilatoria en Ligibya). Hierbij was het belangrijkste knelpunt onvoldoende inzicht in het ontstaan van de benthische blauwalgmatten.

\section{Streefbeeld}

Het streven is inzicht krijgen de oorzaken van de toegenomen problemen met benthische blauwalgen en inzicht krijgen welke maatregelen genomen kunnen worden om de overlast te verminderen.

\section{Aanpak}

$\mathrm{Er}$ is uitgebreid onderzoek gedaan naar de benthische blauwalgen. Met behulp van exclosures is onderzocht wat het effect is van het massaal voorkomen van exotische zwartbekgrondels op de benthische blauwalgen. Verder is gekeken wat de effecten zijn van maaien van de ondergedoken waterplanten op het voorkomen benthische blauwalgen. In 2018 worden experimenten uitgevoerd waarbij benthische blauwalgmatten worden bedekt met zand.

\section{Tijdslijn}

De onderzoeken zijn gestart in 2015 en gestopt in 2017.

\section{Resultaten}

- $\quad$ Er is geen indicatie dat maaien van waterplanten een geschikte maatregel is om de bedekking met benthische blauwalgen te doen afnemen.

- Het is niet mogelijk een uitspraak te doen of uit te sluiten dat zwartbekgrondels effect hebben op benthische blauwalgen.

- De bedekkingen van de benthische blauwalgen variëren sterk in de tijd.

- In de eerste 6 meter vanaf de waterlijn hebben blauwalgenmatten mogelijkheden zich te ontwikkelen op verschillende substraten.

De resultaten van het aanbrengen van zandpakketten zijn nog niet bekend.

\section{Het gebruik van een waterdrone die zwerfvuil opruimt uit oppervlaktewater (o.a. plastics): Waste Shark.}

\section{Setting}

De gemeente Dordrecht gaat experimenteren met een aquadrone bij het schoonmaken van sloten en singels in de stad. De zogeheten WasteShark wordt ingezet om (plastic) afval en kroos te verzamelen. De proef is een gezamenlijk initiatief van het waterschap Hollandse Delta, ontwikkelaar RanMarine Technology, aannemer Krinkels, Cirkellab en de gemeente Dordrecht. Dordrecht is de samenwerking aangegaan omdat het zeer geïnteresseerd is in innovatieve ideeën om de stad slimmer en toekomstbestendig te maken. De stad maakt de proef met de WasteShark mede mogelijk met budget vanuit Smart City Dordrecht.

\section{Doel}

Testen of het schoonmaken van sloten en singels in de stad met een aquadrone effectief is. Dordrecht ziet in het experiment ook een kans om te kijken of kostenbesparingen te behalen zijn. Op dit moment zijn twee mensen een dag(deel) per week aan het werk om het afval op te vissen uit de Spuihaven. Dat levert per keer zo'n drie vuilniszakken vol plastic e.d. op. Als de proef slaagt, zal de aannemer die het werk uitvoert (Krinkels) de aquadrone aanschaffen. De gemeente wil de proef ook gebruiken om mensen bewust te maken van het afval dat in de Spuihaven drijft. De inzet van de WasteShark verbetert de waterkwaliteit en draagt zo bij aan een schone en aantrekkelijke omgeving. Dordtenaren kunnen daar 
zelf een bijdrage aan leveren door geen afval in het water (en op straat) te gooien. Er zijn ideeën om van het afval dat de WasteShark tijdens de proef ophaalt een kunstwerk te maken.

\section{Streefbeeld}

Minder plastic in het water.

\section{Aanpak}

De op afstand bestuurbare aquadrone dankt zijn naam aan de 'haaienbek'. Hiermee wordt al varend afval en kroos verzameld, ook op moeilijk begaanbare plekken. De WasteShark heeft sensoren waarmee de waterdiepte, de watertemperatuur en het zuurstofgehalte in het water te meten zijn.

\section{Tijdslijn}

Demissionair wethouder Rinette Reynvaan (Stadsbeheer) en heemraad Cok Sas van waterschap Hollandse Delta geven op maandag 9 april met de samenwerkingspartners het officiële startsein voor de proef. De proef duurt drie maanden. De WasteShark zal in actie komen in de Spuihaven, een van oorsprong middeleeuwse gracht die gold als scheiding tussen de 'stad' en de landerijen.

\section{Resultaten}




\begin{tabular}{|c|c|c|c|c|}
\hline $\begin{array}{l}\text { adract } \\
\text { tatum }\end{array}$ & 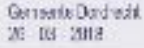 & $\begin{array}{l}\text { intie: } \\
\text { testzantsnazm }\end{array}$ & 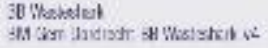 & $\begin{array}{l}\text { inslerisal specs } \\
\text { Mearten }\end{array}$ \\
\hline
\end{tabular}

$9: 2 \mathrm{~cm}$

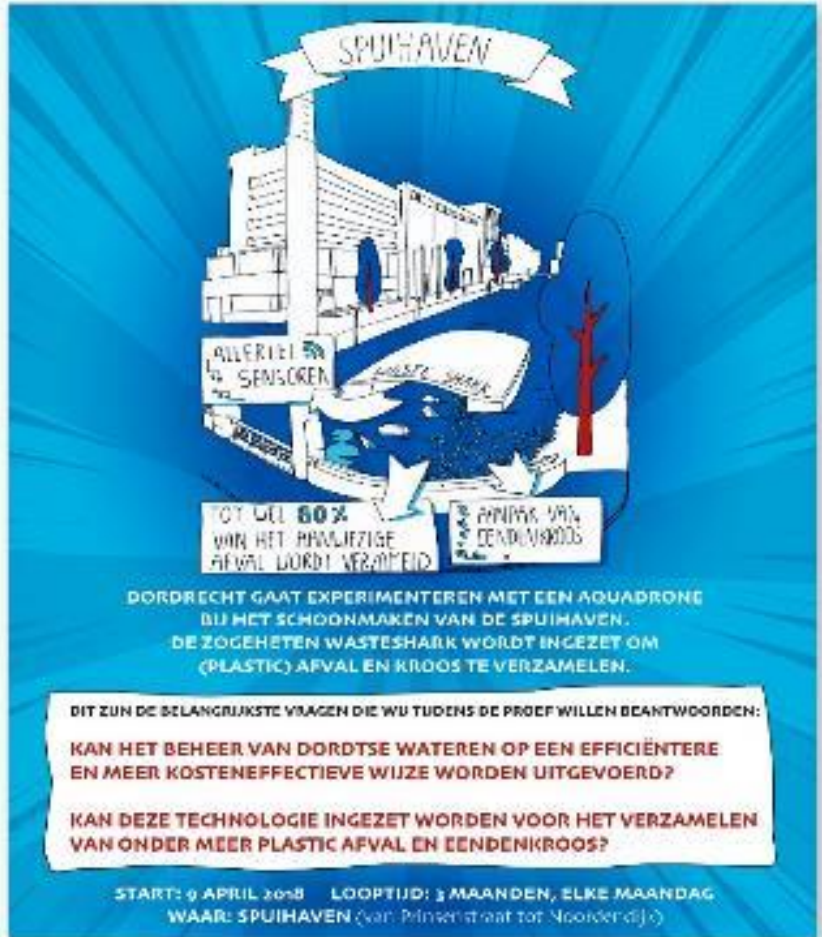

103 un

*

$153 \mathrm{um}$.

$150 \mathrm{~cm}$. pantners:

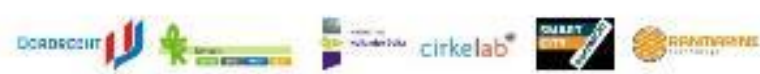

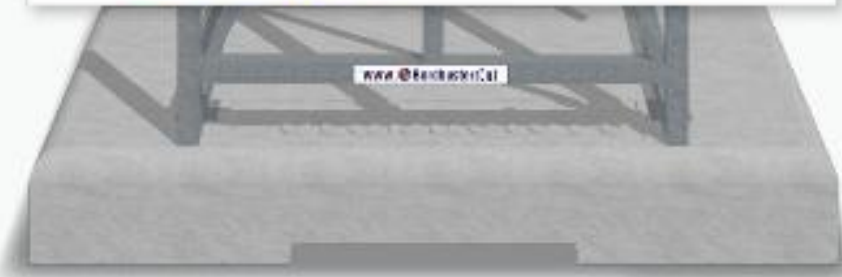

(3) Bordbusters

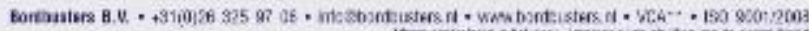

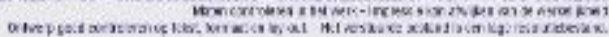

Informatiebord project 


\section{Projecten waterschap Zuiderzeeland}

Aangeleverd door Martijn Hokken en Harry Bouwhuis.

\section{Robuuste herinrichting Hoge Dwarsvaart}

\section{Aanleiding van het project}

De Hoge Dwarsvaart is een zijwater van het KRW-waterlichaam Hoge Vaart, vlak nabij hoofdgemaal Lovink. De vaarten in Flevoland behoren tot het type M6b, grote ondiepe kanalen met scheepvaart. De Hoge Dwarsvaart is eveneens onderdeel van de provinciale EHS. Beleidskaders uit het provinciaal Omgevingsplan en Waterbeheerplan 2002-2005 en de MER-procedure rondom de aanleg van gemaal Lovink vormden de aanleiding tot de start van dit project.

\section{Doel}

Het doel van het project is een belangrijke bijdrage te leveren aan een robuust watersysteem, zowel vanuit KRW- als WB21-perspectief. In 2003 was de Hoge Dwarsvaart nog een sterk biologisch verarmd watersysteem. Dit betekent dat organismen die je er in principe zouden kunnen aantreffen door het grote gebrek aan structuurdiversiteit niet aanwezig waren. De Hoge Dwarsvaart vormde ecologisch dan ook geen goede verbinding met het omringende Harderbos. Natuurmonumenten en het waterschap hadden dezelfde doelen: substantieel areaal natte natuur toevoegen aan deze lokale regio.

\section{Streefbeeld}

Geschikt leefgebied voor gidssoorten als otter, bever en ijsvogel, waarbij eveneens een robuuste impuls gegevens wordt (hotspot) aan de KRW structuurdiversiteitsopgave.

\section{Aanpak}

In het kader van het project is er ca. 6 hectare extra open water gecreëerd met zeer flauwe taluds. Het ontwerp behelst natuurvriendelijke oevers met robuuste, natte ecologische stapstenen en locale plasbermen. Natuurmonumenten heeft de omgeving boom- en stobbenvrij opgeleverd. Waterschap is directievoerder van de robuuste herinrichting en vergravingen. Project is uitgevoerd in 2004-2005.

\section{Resultaat}

De aanleg van dit type natuurvriendelijke oevers heeft in sterke mate de structuurdiversiteit verhoogd. Meer structuurdiversiteit is één van de belangrijkste maatregelen om te voldoen aan de KRWdoelstellingen. Mede door de omvang van de ingreep heeft het een grote ecologische doorwerking op het omringende watersysteem. Gidssoorten als otter, bever, ijsvogelen roerdomp vinden inmiddels hier ruimschoots hun leef en verblijfhabitat. Het waterschap voldoet, mede dankzij icoonproject Hoge Dwarsvaart als robuuste ecologische stapsteen, voor wat betreft de Hoge Vaart aan de KRW doelen qua: nutriënten, overige waterflora, macrofauna en vissen!!!

Zie ook link: http://www.kaderrichtlijnwater.natuurmedia.nl/

\section{Financiële lasten.}

SGB-subsidie en zandopbrengsten hebben de kosten sterk gedrukt. De totale investering bedroeg $€$ 185.000 . 


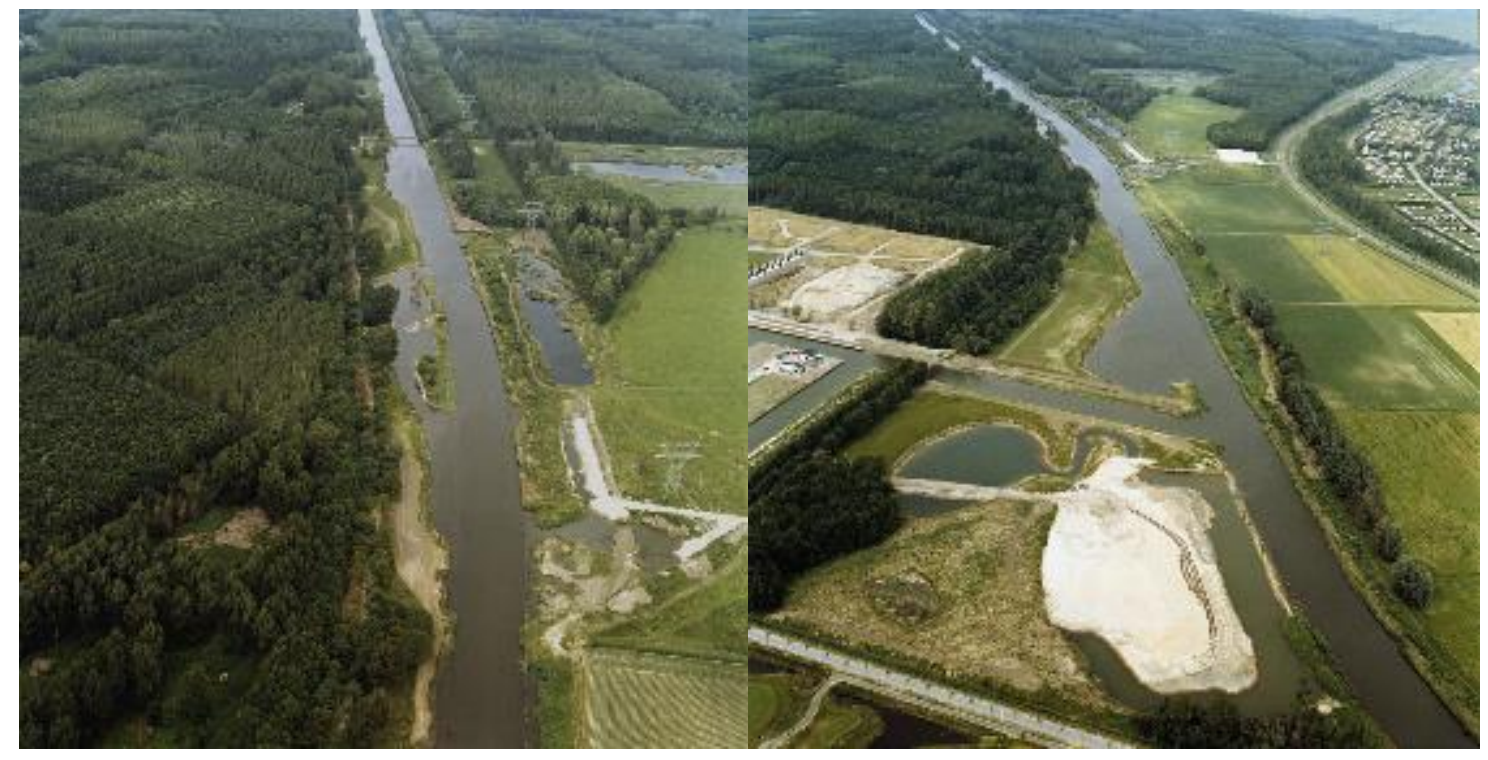

Overzicht herinrichting Hoge Dwarsvaart.

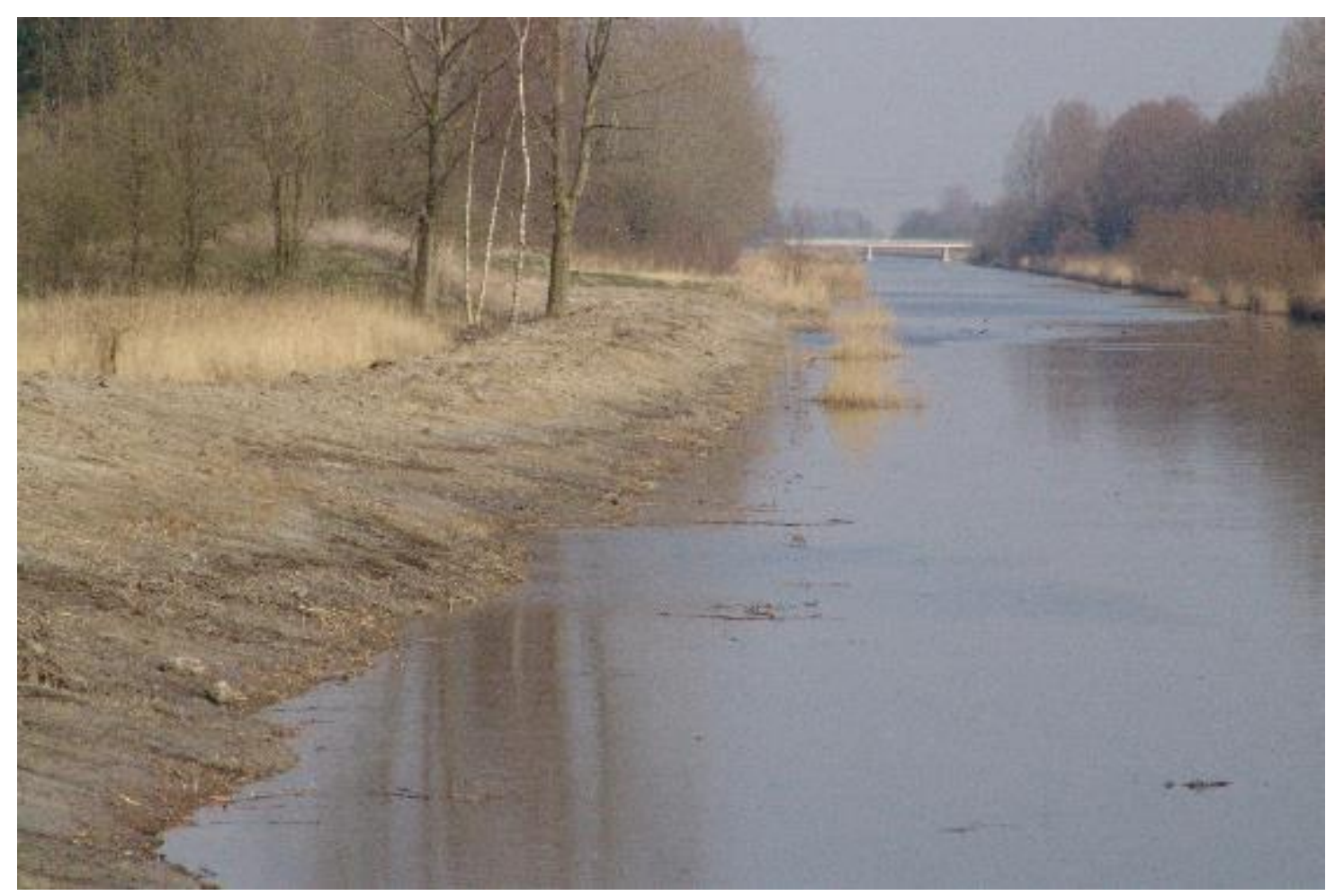

Verflauwing oevers. 


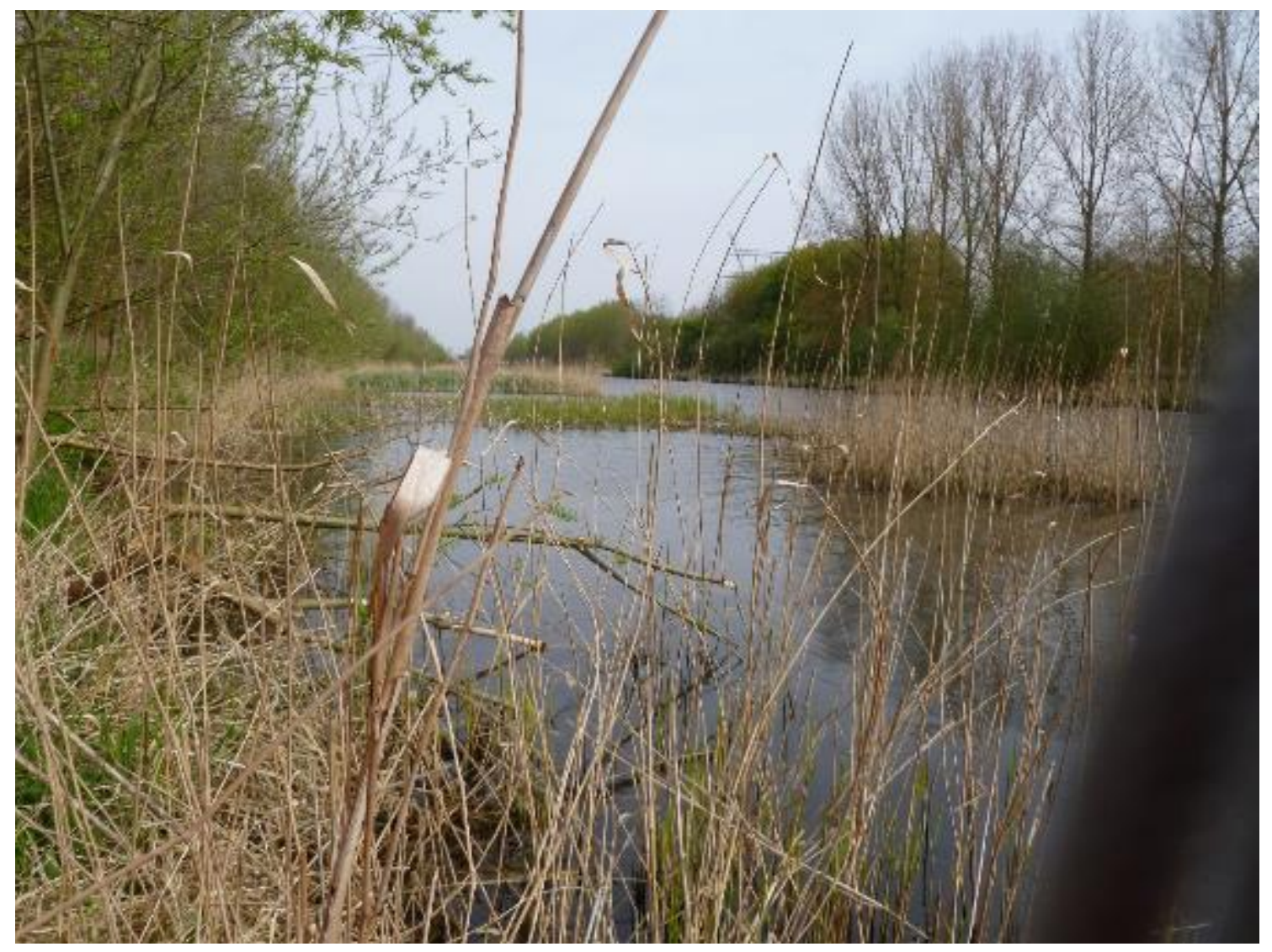

Natuurvriendelijke oever vijf jaar na aanleg. 
Projecten hoogheemraadschap Rijnland

Aangeleverd door Bart Schaub en Lucienne Vuister.

\section{Reeuwijkse plassen}

Informatie over dit project is hier te vinden:

https://www.rijnland.net/werk-in-uitvoering/plassen-en-meren/reeuwijkse-plassen

\section{Een betere waterkwaliteit in de bollenteelt door ijzerzand}

Informatie over dit project is hier te vinden:

https://www.rijnland.net/actueel/nieuws/nieuws-2017/een-betere-waterkwaliteit-in-de-bollenteelt-doorijzerzand 


\section{Projecten waterschap Vechtstromen}

Aangeleverd door Gertie Schmidt.

\section{Beneden Regge}

\section{Setting}

De Regge is de belangrijkste rivier in het westelijk deel van Twente. De Beneden Regge vormt het benedenstroomse deel en loopt van stuw Hancate tot aan de uitmonding in de Overijsselse Vecht. De Beneden Regge geldt als KRW-waterlichaam van het type R6 ('langzaam stromend riviertje op zand').

\section{Doel}

In de vorige eeuw is de Beneden Regge gekanaliseerd en genormaliseerd, hetgeen geleid heeft tot een sterke reductie van aan (half) natuurlijke riviertjes gebonden natuurwaarden.

\section{Streefbeeld}

Er wordt gestreefd naar de volgende situatie voor de Beneden Regge:

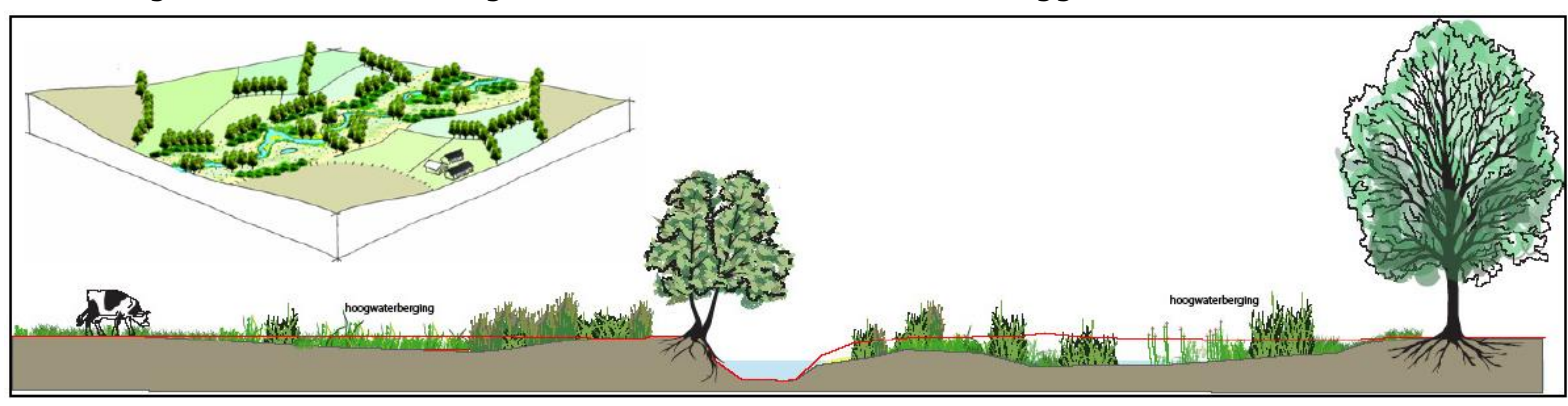

Schets van het streefbeeld

\section{Aanpak}

Als onderdeel van de Reggevisie, een omvangrijk meerjarenprogramma gericht op herstel van een dynamisch en veerkrachtig watersysteem op basis van WB21 en KRW, is in de periode 2010-2015 de Beneden Regge over een lengte van circa $6 \mathrm{~km}$ heringericht. Daarbij is de oorspronkelijk rivierloop min of meer hersteld, is het zomerbed verontdiept en versmald en is de verbinding met het rivierdal hersteld; piekberging vindt dalbreed plaats. Zowel het zomer- als winterbed zijn in extensief beheer.

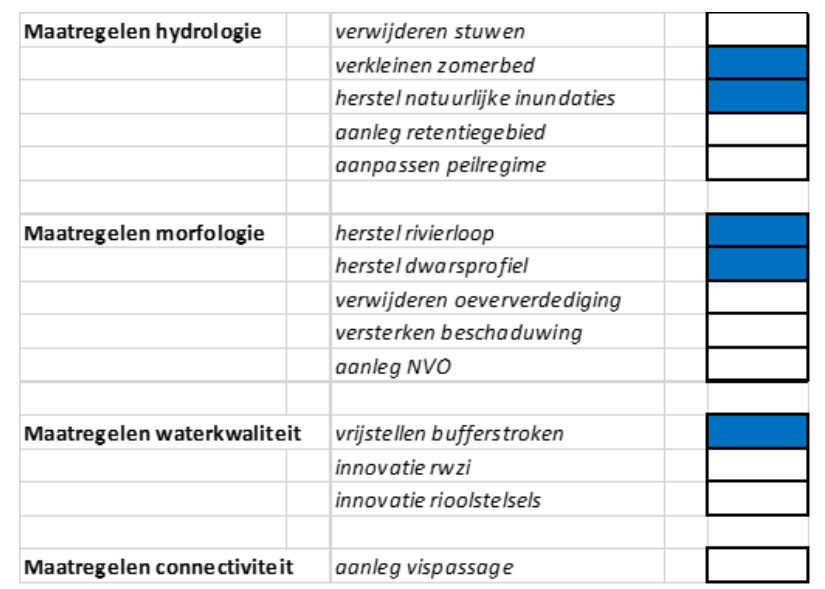

Maatregelen Beneden Regge. 


\section{Resultaten}

De resultaten van het monitoringsprogramma laten een voorzichtige verbetering zien van de biologische waterkwaliteit van de Beneden Regge. De recente meetreeks is echter nog te kort voor een definitieve evaluatie.
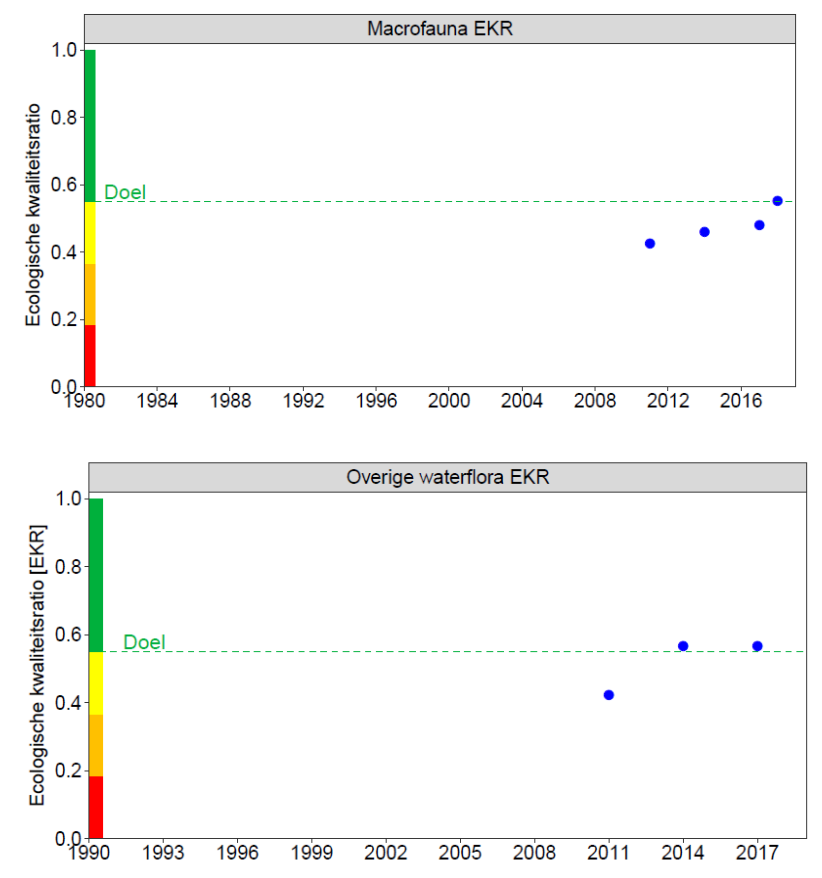

Veranderingen in de EKR macrofauna en macrofyten op meetpunt 01.037.

\section{Hagmolenbeek (project Twickel)}

\section{Setting}

De Hagmolenbeek is een grensoverschrijdende beek in het zuidelijke deel van Twente. De beek maakte oorspronkelijk deel uit van het stroomgebied van de Regge, maar bij de aanleg van het Twentekanaal in 1936 is de beek van de Regge afgekoppeld. Sindsdien stroomt het uit op het kanaalpand Eefde-Delden. De Hagmolenbeek is tijdens de dertiger jaren van de vorige eeuw rechtgetrokken, gestuwd en verdiept. De geringe beekkenmerken resulteerde in een lage ecologische kwaliteit.

\section{Doel}

Optimalisatie van het natuurlijk functioneren van het waterlichaam Hagmolenbeek.

\section{Streefbeeld}

Een zo natuurlijk mogelijk functionerende beek.

\section{Aanpak}

In de periode 2012-2013 is nabij Beckum op gronden van het landgoed Twickel een programma uitgevoerd gericht op herstel van een natuurlijk functionerend beeksysteem. Ter plaatste heeft de beek over circa 4 km het karakter van een vrij afstromende, natuurlijke weidebeek gekregen. Zowel het beekprofiel, dat sterk versmald en verontdiept is, als de aanliggende gronden zijn in extensief beheer. Het surplus van oppervlaktewater wordt beekdalbreed geborgen. De uitgevoerde maatregelen passen in 
een breder uitvoeringsprogramma gericht op optimalisatie van het natuurlijk functioneren van het waterlichaam Hagmolenbeek.

\begin{tabular}{|l|l|l|}
\hline Maatregelen hydrologie & verwijderen stuwen & \\
\hline & verkleinen zomerbed & \\
\hline & herstel natuurlijke inundaties & \\
\hline & aanleg retentiegebied & \\
\hline & aanpassen peilregime & \\
\hline Maatregelen morfologie & herstel rivierloop & \\
\hline & herstel dwarsprofiel & \\
\hline & verwijderen oeververdediging & \\
\hline & versterken beschaduwing & \\
\hline & aanleg NVO & \\
\hline Maatregelen waterkwaliteit & vrijstellen bufferstroken & \\
\hline & innovatie rwzi & \\
\hline & innovatie rioolstelsels & \\
\hline & & \\
\hline Maatregelen connectiviteit & aanleg vispassage & \\
\hline
\end{tabular}

Maatregelen Hagmolenbeek.

\section{Resultaten}

De resultaten van het monitoringsprogramma laten een voorzichtige verbetering zien van de biologische waterkwaliteit van de Hagmolenbeek ter plaatse van het herstelproject. De recente meetreeks is echter nog te kort voor een definitieve evaluatie.
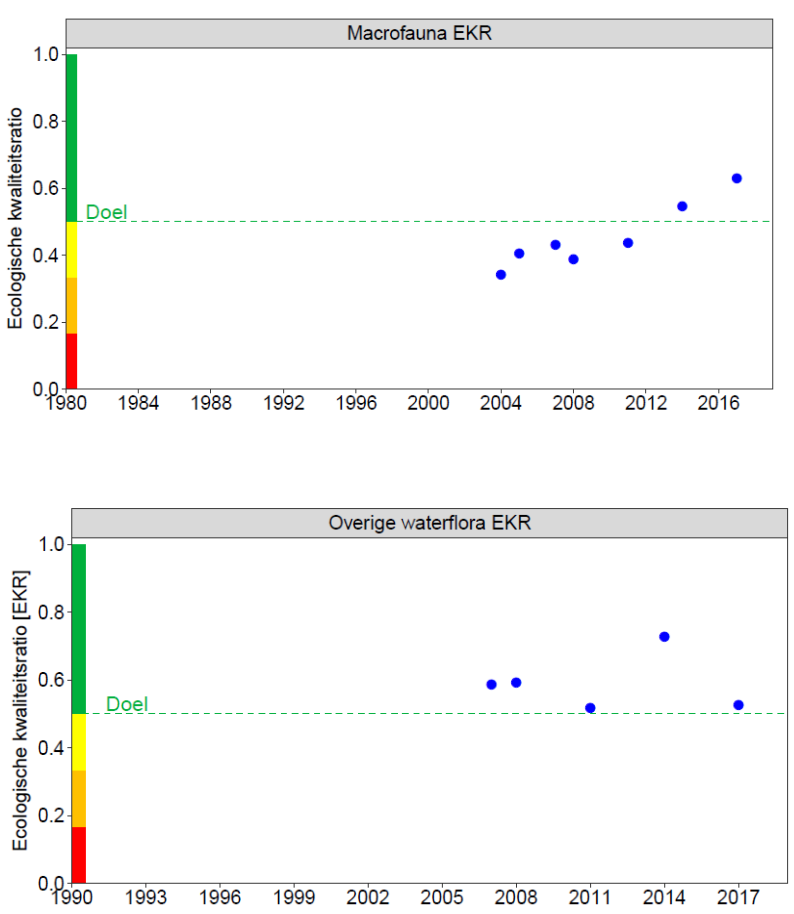

Veranderingen in EKR macrofauna en macrofyten op meetpunt 20.074. 

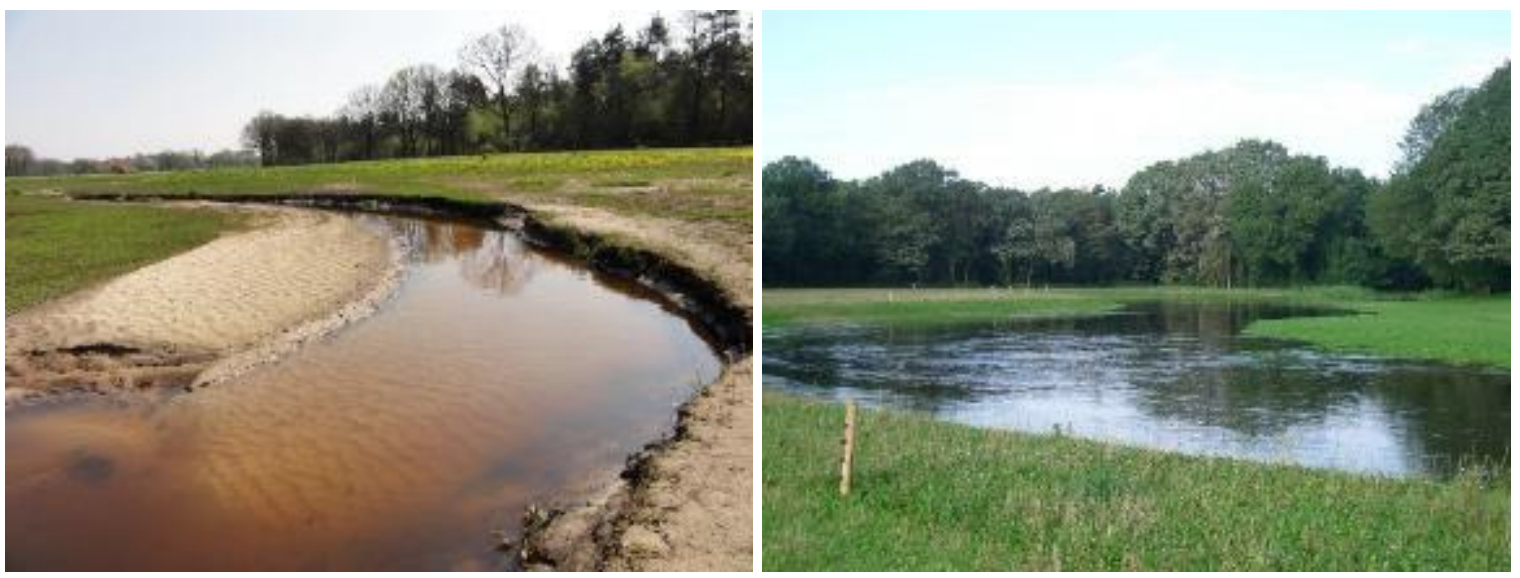

Hagmolenbeek in de huidige situatie bij voorjaarsafvoer (links) en piekafvoer (rechts).

\section{Deurningerbeek}

\section{Setting}

De Deurningerbeek ontspringt nabij Oldenzaal op de gelijknamige stuwwal en stroomt van oost naar west. De beek is onderdeel van het KRW-waterlichaam Oude Bornsebeek, dat op haar beurt weer deel uitmaakt van het stroomgebied van de Regge. In KRW-termen wordt de Deurningerbeek getypeerd als een 'langzaam stromende midden/benedenloop op zand (R5)'. De Deurningerbeek is in het verleden gekanaliseerd, genormaliseerd en verdiept en kon worden gekarakteriseerd als een slootbeek met weinig natuurlijke beekkenmerken.

\section{Doel}

In de periode $2012-2013$ is een programma uitgevoerd gericht op herstel van een natuurlijk functionerend beeksysteem.

\section{Streefbeeld}

Een zo natuurlijk mogelijk functionerend beeksysteem.

\section{Aanpak}

Ter plaatste van Withagsmeden heeft de beek over circa $2200 \mathrm{~m}$ het karakter van een vrij afstromende, natuurlijke bosbeek gekregen. Zowel het beekprofiel, dat sterk versmald en verontdiept is, als de aanliggende natuurstroken met overwegend houtwal/bosbeheer zijn in extensief beheer. Het surplus van oppervlaktewater wordt beekdalbreed geborgen. De uitgevoerde maatregelen passen in een breder uitvoeringsprogramma gericht op optimalisatie van het natuurlijk functioneren van het waterlichaam Oude Bornsebeek. 


\begin{tabular}{|l|l|l|}
\hline Maatregelen hydrologie & verwijderen stuwen & \\
\hline & verkleinen zomerbed & \\
\hline & herstel natuurlijke inundaties & \\
\hline & aanleg retentiegebied & \\
\hline & aanpassen peilregime & \\
\hline Maatregelen morfologie & herstel rivierloop & \\
\hline & herstel dwarsprofiel & \\
\hline & verwijderen oeververdediging & \\
\hline & versterken beschaduwing & \\
\hline Manleg NVO & \\
\hline & vrijstellen bufferstroken & \\
\hline & innovatie rwzi \\
\hline Maatregelen connectiviteit & innovatie rioolstelsels & \\
\hline Maatregleg vispassage & \\
\hline
\end{tabular}

Maatregelen Deurningerbeek.

\section{Resultaten}

De resultaten van het monitoringsprogramma laten een voorzichtige verbetering zien van de biologische waterkwaliteit van de Deurningerbeek. De recente meetreeks is echter nog te kort voor een steekhoudende evaluatie.
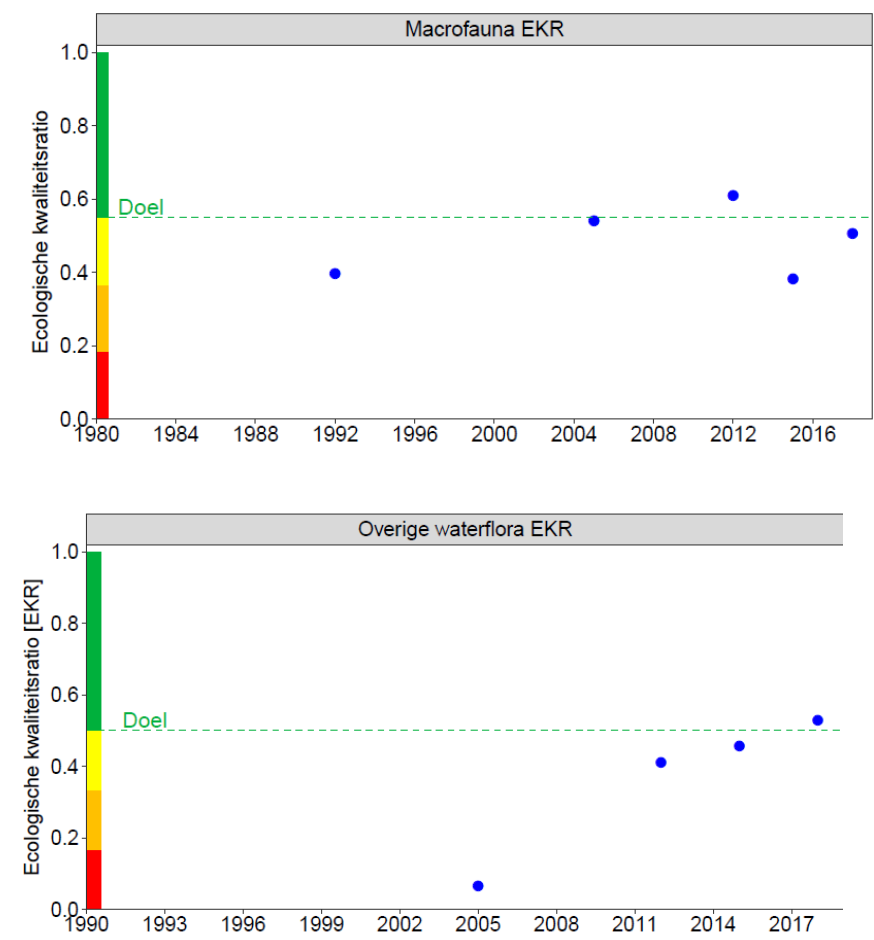

Veranderingen in EKR macrofauna en macrofyten op meetpunt 16.019. 


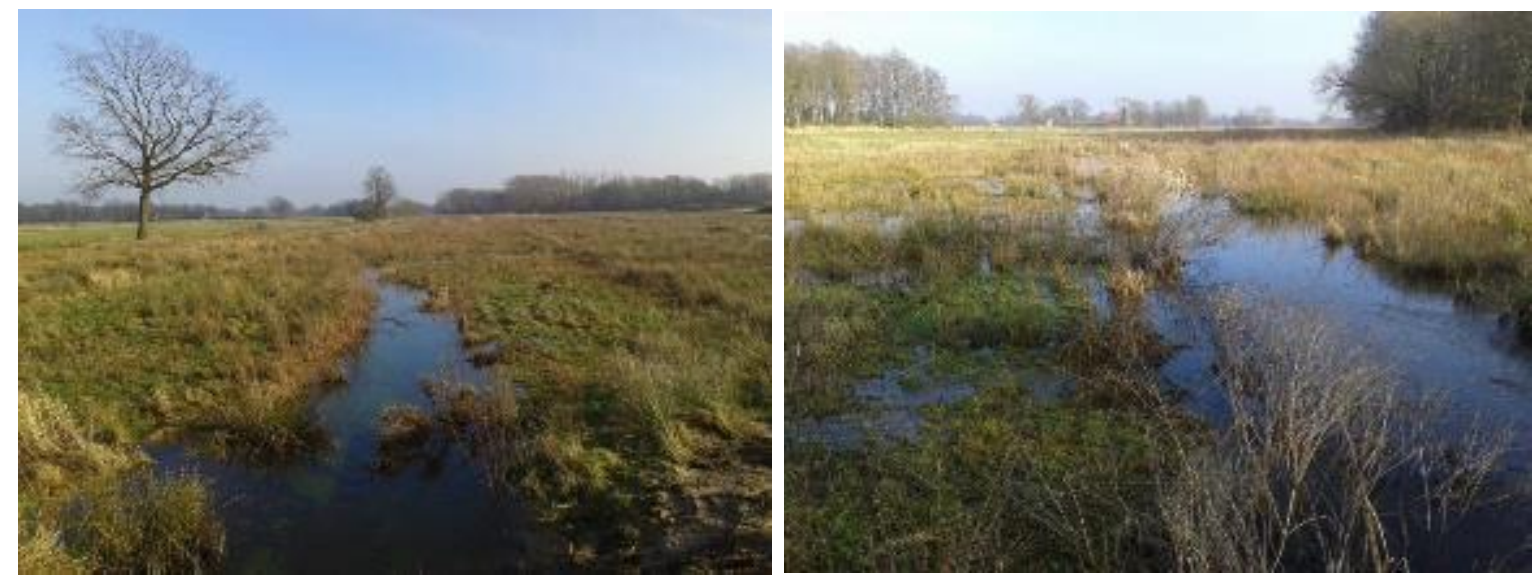

Deurningerbeek in de huidige situatie bij winterafvoeren. 


\section{Projecten hoogheemraadschap de Stichtse Rijnlanden}

Aangeleverd door Nikki Dijkstra en Peter Heuts.

\section{Vismigratie Rijnwest}

\section{Setting}

Vismigratie tussen rijkswateren, regionale en lokale wateren. Dit is onderdeel van het LIFE IP Deltanatuur actie C3-1 Vismigratie regionale wateren. Deelonderzoek fase 1: KRW waterlichaam Langbroekerwetering (LBW). Veel onderzoek is uitgevoerd naar vismigratie en dispersie van rheofiele vissoorten in stromende wateren. Weinig is bekend over de verplaatsing van algemene vissen in stilstaande wateren en poldersystemen. Dit onderzoek richt zich op de vismigratie en dispersie in dit soort systemen.

\section{Doel}

Onderzoek naar regionale en lokale vismigratie in poldersystemen; vaststellen belang overig water voor de visstand; beter inzicht krijgen in het effect van vismigratiemaatregelen.

\section{Streefbeeld}

Kennis van de verplaatsing van vissen in stilstaande wateren tussen de verschillende habitats.

\section{Aanpak en tijdslijn}

Fase 1: 2018-sept 2019; Onderzoek LBW naar regionale en lokale vismigratie mbv pit-tag onderzoek. Op dit moment zijn meer dan 1000 vissen getagd. Zes De Wit kamervispassages zijn voorzien van detectieantennes bij de in- en uitgang, en soms ook in de kamers zelf. Ook vier stuwen in de LBW zijn afgedekt met drijvende antennes.

Fase 2: 2019-2020; Onderzoek naar vismigratie tussen poldersystemen en rijkswateren. Wordt nog nader uitgewerkt t.z.t.

\section{Resultaten}

Verwachte resultaten LBW onderzoek:

- Inzicht in de verplaatsing van verschillende vissoorten binnen het onderzoekgebied;

- Inzicht in het gebruik van de 'De Wit' vispassages in het onderzoekgebied;

- Inzicht in de stroomafwaartse migratie over stuwen en via vispassages door de verschillende vissoorten;

- Onderscheiden van de verschillende habitat in het onderzoekgebied en het gebruik daarvan door de verschillende vissoorten. 


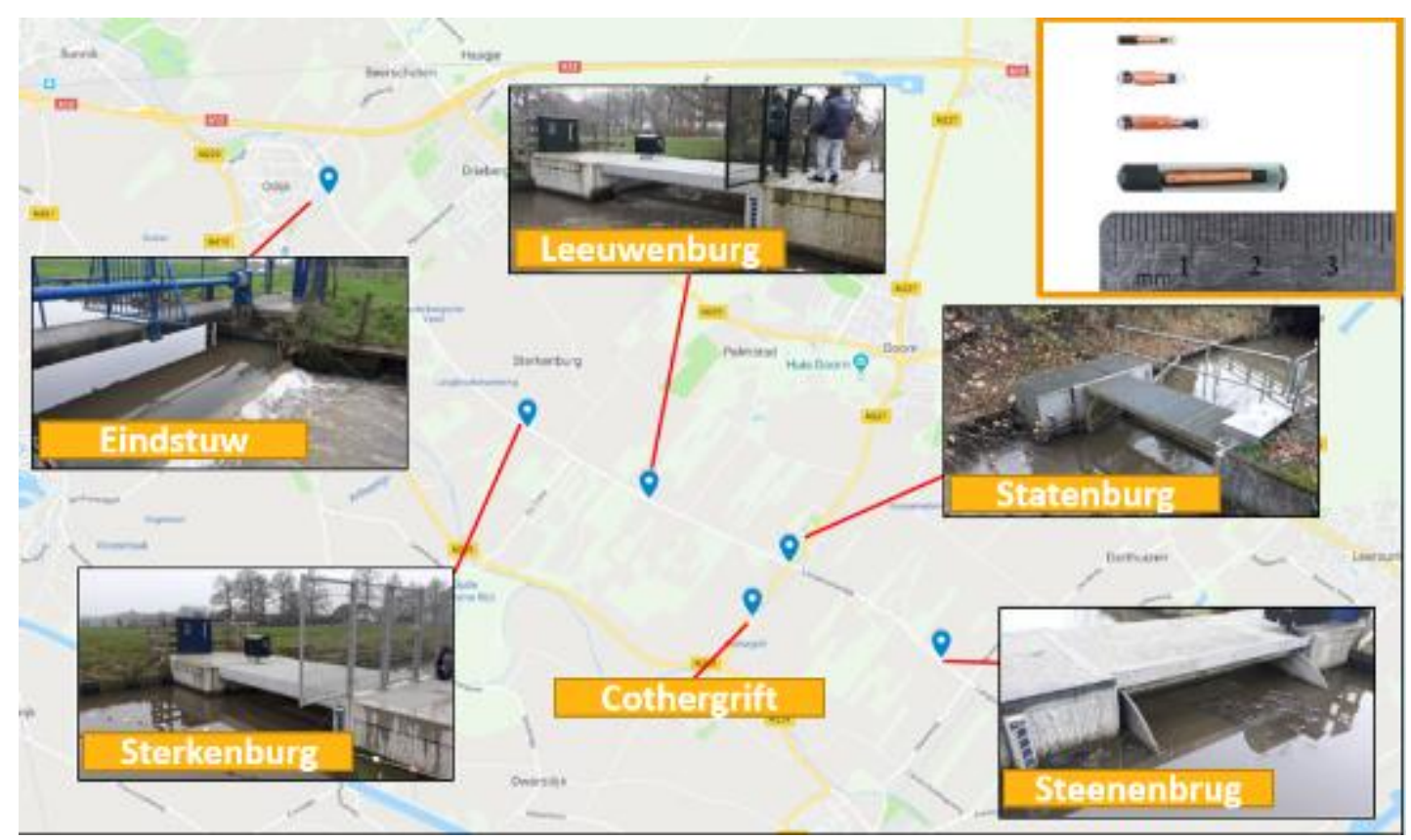

Locatie van de vijf stuwen in de Langbroekerwetering en 1 stuw in een zijtak (Cothergroft). Bovenin rechts zijn de PIT-tags weergegeven die zijn ingebracht bij meer dan 1000 verschillende vissen in de Langbroekerwetering.

\section{Modelonderzoek vispassage.}

\section{Setting}

De Wit vispassages zorgen voor verbindingen tussen rijkswateren en regionale wateren (o.a. KRWwaterlichamen. Regionale wateren zijn door deze vispassages ook in verbinding gebracht met lokale wateren (overig water). Sommige vispassages fungeren goed. Grote vispassages hebben een lage efficiëntie m.b.t. het aantal gepasseerde vissen. Met een modelonderzoek dat wordt uitgevoerd door en in samenwerking met Movaris wordt de invloed van de stroomsnelheid en de turbulentie onderzocht en de mogelijke implicaties daarvan op de passeerbaarheid voor verschillende vissoorten.

\section{Doel}

Doel van dit modelonderzoek is om meer inzicht te genereren in de waterstroming in de 'De Wit'-passage en om vast te stellen welke invloed ontwerpkeuzes hebben op de effectiviteit (aantal migrerende vissen) van de vispassage. Met behulp van deze informatie kan vervolgens een optimalisatie worden gemaakt van de vispassage voor specifieke soorten en locaties.

\section{Streefbeeld}

Nieuw aan te leggen vispassages zijn uitgevoerd conform de optimalisaties. Bestaande vispassages worden geoptimaliseerd door aanleg rustkamers en reductie van de turbulentie door het aanbrengen van obstakels.

\section{Aanpak en tijdslijn}


Optimalisatie volgt KRW-tijdspad. Klaar in 2027. Afronding modelonderzoek: 2018; Selectie optimalisaties voor praktijktesten: 2019; Uitvoeren praktijktesten: 2019-2021; Toepassen optimalisaties: 2021-2027.

\section{Resultaten}

Kleine vissen hebben doorgaans meer 'hinder' van turbulentie en een hoge stroomsnelheid. Een optimale vispassage heeft dan beperkte vensterafmetingen, vensters zoveel mogelijk uit lijn geplaatst en kleine peilverschillen. Grotere vissen hebben juist vooral 'hinder' van de terugstroming. Door hun vaak hogere sprint- en kruissnelheid zijn hoge stroomsnelheden in de vensters vaak een minder groot obstakel, maar door hun grotere hoogte raken ze door terugstroming sneller in de war met betrekking tot de te volgen richting. Voor grotere vissen is het van belang om juist de vensterafmetingen te verhogen. Beschreven optimalisaties worden in de praktijk getest.

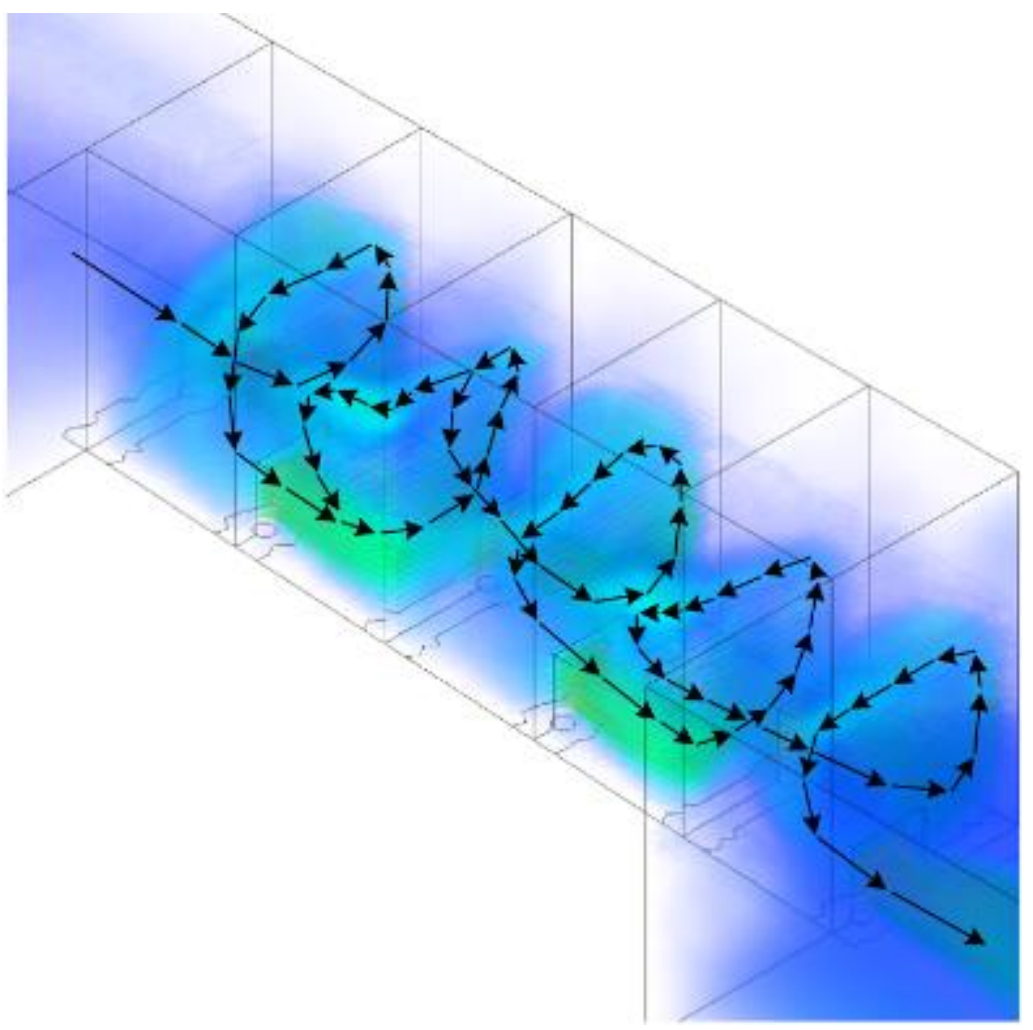

Stromingspatroon van het basismodel. Duidelijk zichtbaar is de sterke mate van terugstroming in de kamers.

\section{Nevengeul Kromme Rijn bij Odijk}

\section{Setting}

De Kromme Rijn is een sterk veranderd waterlichaam van watertype R6: langzaam stromend riviertje op zand/klei. De Kromme Rijn meandert vanaf de Nederrijn bij Wijk bij Duurstede via Cothen, Werkhoven, Odijk en Bunnik naar Utrecht. De aan- en afvoerfunctie is belangrijk voor de nachtvorstbestrijding ten behoeve van fruitteelt en voor de doorspoeling van de grachten van Utrecht. De Kromme Rijn is deels gekanaliseerd waardoor oeverbeschoeiingen zorgen voor abrupte overgangen van land naar water. De rivier heeft een functie als kanowater en maakt onderdeel uit van een ecologische verbindingszone. 


\section{Doel}

Herstel van een natuurlijke afvoer, met een natuurlijk peilverloop en uitgestrekte inundatiezones is niet mogelijk vanwege de functies, maar ook vanwege aanliggend landgebruik zoals landbouw en stedelijk gebied. De belangrijkste drukken zijn de steile en beschoeide oevers en het ontbreken van variatie in stroomsnelheid. Specifieke stromingminnende soorten vis en macrofauna ontbreken onder andere daarom in het systeem. Om de oeverinrichting te verbeteren wordt veel geïnvesteerd in de aanleg van natuurvriendelijke oevers. Andere verbetermaatregelen zijn de aanleg van een stromende nevengeul en het inbrengen van (hout)substraten.

\section{Streefbeeld}

De Kromme Rijn heeft vanwege zijn sterk veranderde karakter en de beperkte mogelijkheden voor verbetering aangepaste KRW doelen. Het goed ecologisch potentieel is lager dan standaard $(=\operatorname{GEP} 0,6)$, namelijk 0,44 voor vis, 0,56 voor macrofauna en 0,58 voor macrofyten. Toch is het, met name voor vis dat nu lager dan 0,2 haalt (klasse slecht), nog een lange weg voor dit bereikt is.

\section{Aanpak en tijdslijn}

Aan de oostzijde van de Kromme Rijn ter hoogte van Odijk is begin 2015 een nevengeul gegraven die aan de zuidzijde wordt gevoed door de Langbroekerwetering. Aan de noordzijde komt de nevengeul uit op de Hoge Woerdwetering, die uitmondt in de Kromme Rijn. Door de aanleg van de nevengeul, met hierin verschillende soorten substraat, ontstaan plaatselijk stroomversnellingen, wat (rheofiele) soorten ten goede kan komen. Daarnaast ontstaat door de toepassing van verschillende substraten meer habitatdiversiteit. Om het resultaat vast te stellen, is in de eerste drie jaar na aanleg monitoring uitgevoerd van vissen en macrofauna. De bemonsteringen zijn geconcentreerd op- en rond de verschillende substraten.

\section{Resultaten}

In de nevengeul worden aardig wat stromingsindicatoren gevonden. Een voorbeeld is de zeldzame stromingsminnende haft Baetis fuscatus die in 2017 in de nevengeul is gevonden. De soort is in het voor- en najaar en op verschillende locaties in de nevengeul gevangen, waardoor er sprake moet zijn van een populatie. Rheofiele vissoorten die gevonden zijn, zijn bijvoorbeeld bermpje, riviergrondel en winde. Naast successen, kent de nevengeul ook aandachtspunten. De vegetatie groeit hard en dreigt de nevengeul dicht te groeien. Ingebrachte houtstructuren brokkelen af en dreigen te verdwijnen. Passend onderhoud is dus noodzakelijk om de functie van de nevengeul voor rheofiele soorten te behouden.

Zie ook: https://www.helpdeskwater.nl/publish/pages/142639/macrofaunanieuwsmail 141 15 maart 2018.pdf

\section{Waterkwaliteitsmodule Tygron Engine}

\section{Setting}

Watersysteemanalyse lijnvormige waterlichamen/watersystemen (dus alles behalve plassen of meren).

\section{Doel}

We misten een analysemethode om snel en accuraat tot een gebiedsdekkende, ruimtelijke gedetailleerde watersysteemanalyse te komen. Oftewel een jaarrond inzicht in de actuele en kritische nutriëntenbelastingen per sloot (dus niet alleen waterlichamen, maar ook het overige water). 


\section{Streefbeeld}

Dat we snel, goed en inzichtelijk alle ESF's ruimtelijk gedetailleerd kunnen analyseren. Momenteel ligt de focus op ESF1, maar in principe zijn alle ESF's er in te integreren.

\section{Aanpak en tijdslijn}

Momenteel zijn we de waterkwaliteitsmodule aan het integreren in de Tygron Engine. De module berekent jaarrond de water- en stoffenbalans per sloot. Dit koppelen we aan een op maat gemaakt metamodel van PCDitch, zodat we de actuele en kritische nutriëntenbelastingen kunnen vergelijken. Tevens bestaat de mogelijkheid om maatregelen door te voeren zoals aanpassing van het peilbeheer, het baggeren, het slootschonen en het landgebruik. De module werkt parallel aan reeds bestaande modules in de Tygron Engine voor bodemdaling (RE:PEAT) en wateroverlast, zodat een integraal inzicht in de effecten van maatregelen ontstaat.

\section{Resultaten}

Zie: https://youtu.be/cuuft7 wbvU

\section{Aquafarm}

Gedetailleerde informatie op: https://www.aquafarm.nl/

\section{De boerensloot leeft}

Zie onderstaande flyer

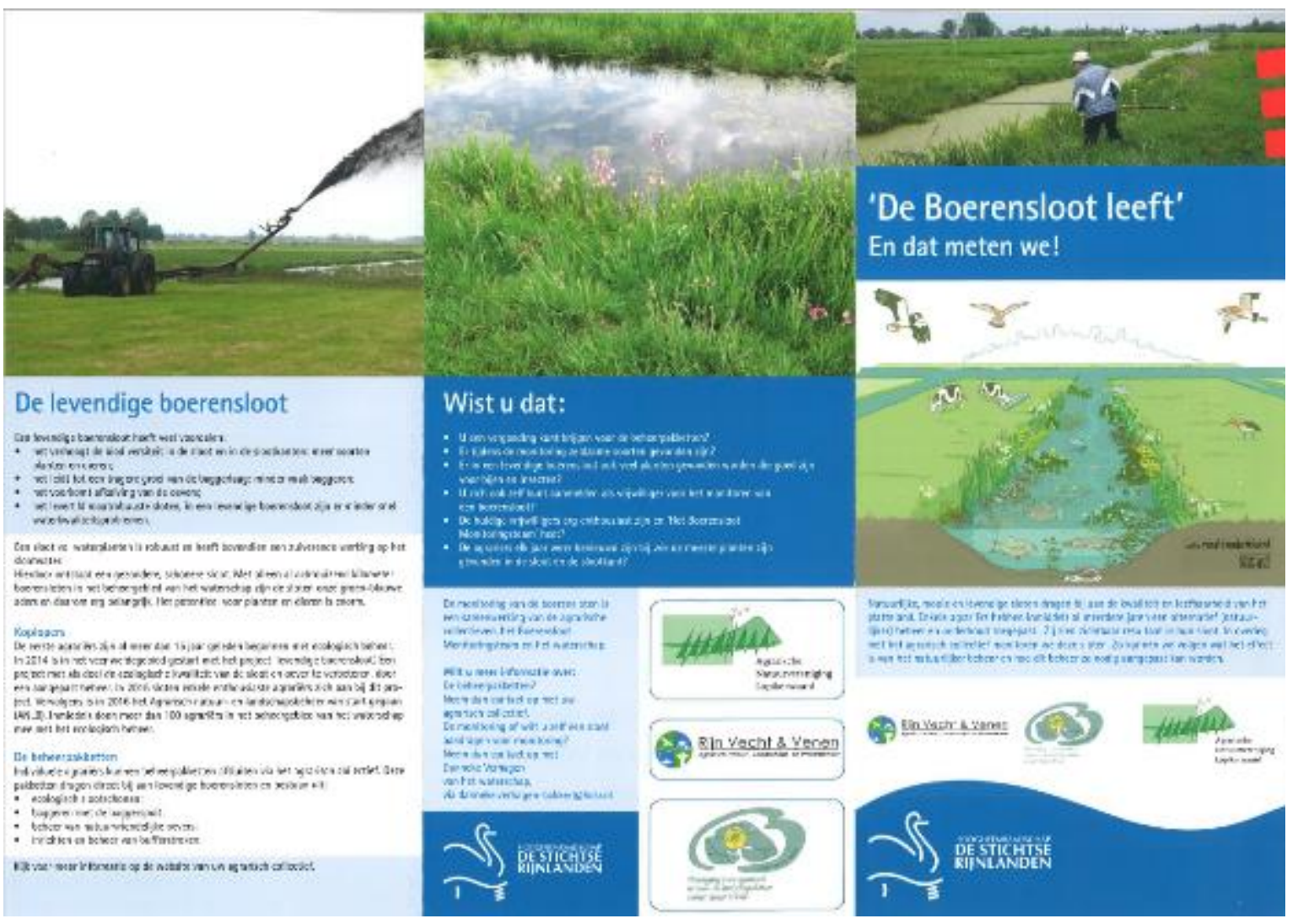




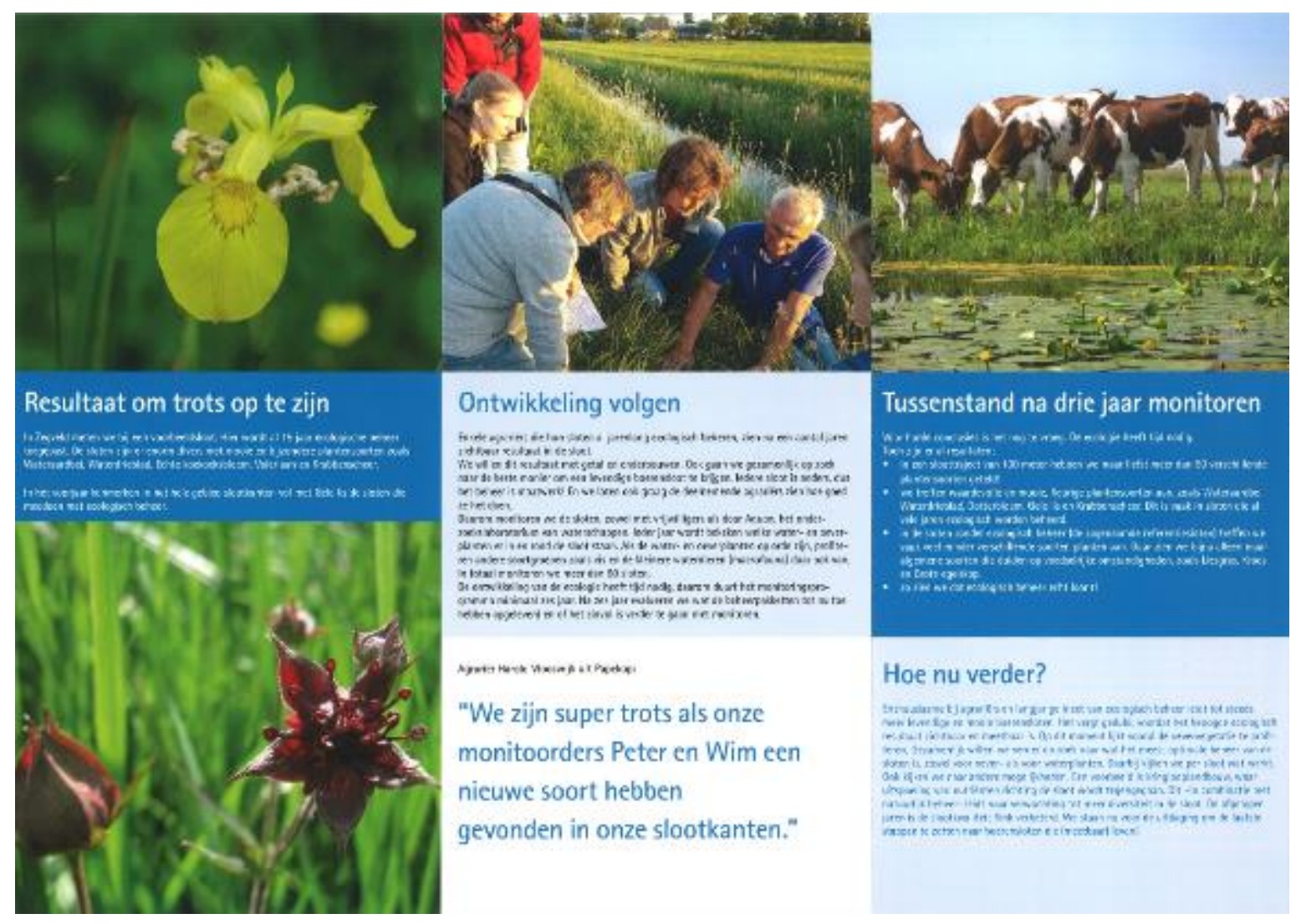




\section{Projecten waterschap de Dommel}

Aangeleverd door Jan van de Graaf en Ineke Barten.

\section{Herkomst nutriënten Reuseldal}

\section{Setting}

De Reusel behoort tot het waterlichaam Reusel/Raamsloop/Achterste Stroom. Het is een R5 type: Langzaam stromende middenloop/benedenloop op zand. Het heeft de status 'Sterk veranderd'. De Reusel is een beekje dat ontspringt in het zuidwesten van Reusel dat stroomt via Reusel en Lage Mierde door Landgoed De Utrecht en vervolgens langs Baarschot en Diessen onder het Wilhelminakanaal door naar Moergestel waarna zij net ten zuiden van Oisterwijk overgaat in de Achterste Stroom. Beken die in de Reusel uitmonden zijn o.a. de Belevensche Loop en de Raamsloop. Het gebied heeft nu een sterk agrarisch karakter. De waterlopen zijn gekanaliseerd, gestuwd en veelal onbeschaduwd.

\section{Doel}

Een beter beeld vormen om gericht waterkwaliteitsmaatregelen te kunnen definiëren. Verbetering van de waterkwaliteit is van belang voor het behalen van de KRW-doelstellingen en de doelen voor N2000-PAS. Herkomstbepaling van nutriënten mbv stroombaanberekeningen en KRW-verkenner; Hoofddoel van het beekherstelproject is: Herstel van de Reusel tav doelstellingen KRW, N2000/PAS, Natte Natuurparel en de realisatie van ca. 200 ha NNB.

\section{Streefbeeld}

Vermindering stikstofbelasting op de Reusel, zodanig dat het onder de KRW-norm komt te liggen. Het beekherstelproject is een integraal project waar naast bij beekherstel aandacht wordt gegeven aan een verbetering van de waterkwaliteit.

\section{Aanpak en tijdslijn}

Het onderzoek naar de herkomst van nutriënten is reeds uitgevoerd. De aanpak hierbij was als volgt:

1. Opstellen overzichtskaarten werking watersysteem;

2. Systeembeschrijving;

3. Uitspoelingsgevoeligheid voor nutriënten;

4. Analyse en uitwerking monitoringsdata (hydrologie en waterkwaliteit);

5. Interpretatie monitoringsdata waterkwaliteit;

6. Globale herkomstanalyse met KRW-verkenner;

7. Herkomstbepaling met stroombaanberekeningen;

8. Integratie en beschrijving kansrijke maatregelen verbetering waterkwaliteit.

Momenteel zoeken we naar maatregelen die binnen het beekherstelproject uitgevoerd kunnen worden. Denk hierbij aan:

1. Landgebruiksveranderingen. Door de gebruiksfunctie om te vormen van landbouw naar andere doeleinden (zoals natuur) zou de aanvoer van nutriënten in Beekdal Reusel-de Mierden sterk verminderen.

2. Kringloopmaatregelen, gericht op het verlagen van de nutriëntenoverschotten.

3. Bodemmaatregelen, gericht op het verminderen van de uit- en afspoeling van nutriënten.

4. Routemaatregelen, gericht op het omzetten of vasthouden van nutriënten voordat ze het gronden oppervlaktewater kunnen belasten. 
5. Daarnaast is er maatregelen die genomen moeten worden door de landelijke en brabantse politiek, denk hierbij aan mestwetgeving e.d.

In 2027 moeten de KRW-doelen behaald zijn.

\section{Resultaten}

Duidelijke relatie N-totaal met de afvoer van de Resuel. Voor P-totaal is de relatie minder duidelijk. Dit komt deels omdat P-totaal sterk gebonden is aan het gehalte zwevend stof. Onder natte omstandigheden draagt het bovenste, door landbouwactiviteiten beïnvloedde grondwater, bij aan de kwaliteit van het oppervlaktewater (m.b.t. N-totaal). De verdeling over de bronnen laat zien dat ca. $80 \%$ van de fosforvracht afkomstig is van uitspoeling en ca. $95 \%$ van de stikstofvacht. Erfafspoeling is met bijna $20 \%$ ook een belangrijke bron voor fosfor. Overstorten zijn wellicht lokaal en periodiek (dag met zware bui in de zomer) relevant als nutriëntenbron, maar in een heel traject van de Reusel op het niveau van het zomerhalfjaar is de bijdrage vanuit overstorten aan de nutriëntenvracht gering.

Uit de stroombaanberekeningen blijkt dat de reistijd van het grondwater in het beekdal en de directe omgeving van de grotere waterlopen in het intrekgebied vrij kort is en doorgaans minder dan 1 jaar bedraagt. Verder naar de beekdalflanken neemt de reistijd toe doordat de neerslag hier infiltreert en een langere weg aflegt naar de drainagemiddelen in het beekdal. Uit de analyse blijkt dat, met uitzondering van NNP de Utrecht, grofweg de helft van het intrekgebied in de hoge of zeer hoge risicoklasse (voor nutriënten belasting van het oppervlaktewater) vallen.
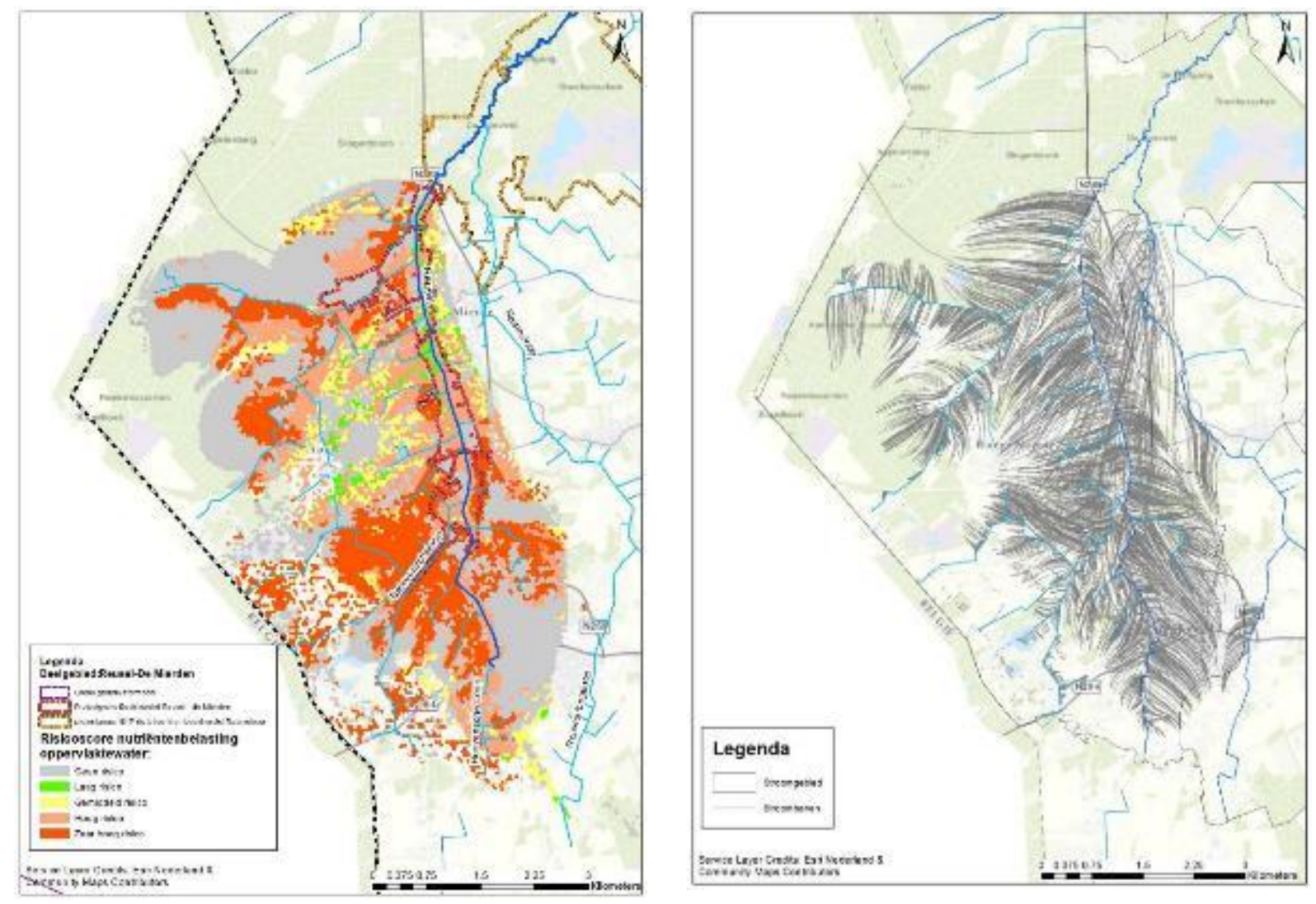

Risicobeoordeling nutriënten (links) en stroombaanberekeningen (rechts) voor het stroomgebied van de Reusel. 


\section{Veldmethode KRW-beoordeling macrofyten overige wateren t.b.v. waterkwaliteitsspoor}

\section{Setting}

Waterschap de Dommel past deze methode toe voor de beoordeling van sloten en kanalen die niet zijn aangewezen als KRW-waterlichaam. Directe aanleiding om de methodiek te ontwikkelen is om sloten waarop een rioolwateroverstort zit te beoordelen op de KRW-doelstelling voor overig water.

\section{Doel}

In het bijzonder willen we dit toepassen om het effect van rioolwateroverstorten te kunnen beoordelen om de urgentie van maatregelen tegen te grote invloed op de waterkwaliteit vast te kunnen stellen. Op deze manier kunnen we als waterschap gemeenten adviseren welke sloten meer of minder prioriteit hebben t.a.v. ecologische doelstellingen.

\section{Streefbeeld}

Geen achteruithang van de ecologie in overige wateren. Doelstelling is een minimale EKR score van 0,2 of 0,3 voor macrofyten. Doelstelling is om de effecten van rioolwateroverstorten te minimaliseren.

\section{Aanpak en tijdslijn}

Voor de beoordeling van de groeivormen macrofyten is maar een beperkt aantal data nodig: de totale bedekking van vijf groeivormen in het water, ongeacht welke soorten daarin voorkomen. De berekening van een beoordeling is te vatten in een vrij eenvoudige formule. Voor elke groeivorm leidt interpolatie van het bedekkingspercentage tussen de percentages op de maatlatgrenzen tot een EKR-score. Het gemiddelde van deze EKR-scores geeft de eindscore, waarbij Kroos en Flab alleen wordt meegenomen in het gemiddeld als de EKR daarvan lager is dan 0,6. Dat is op een eenvoudig veldformulier uitgewerkt. Ook een inschatting van de beoordeling van de soortensamenstelling is op dezelfde manier gedaan. De belangrijkste soorten worden in het veld herkend en ingevuld.
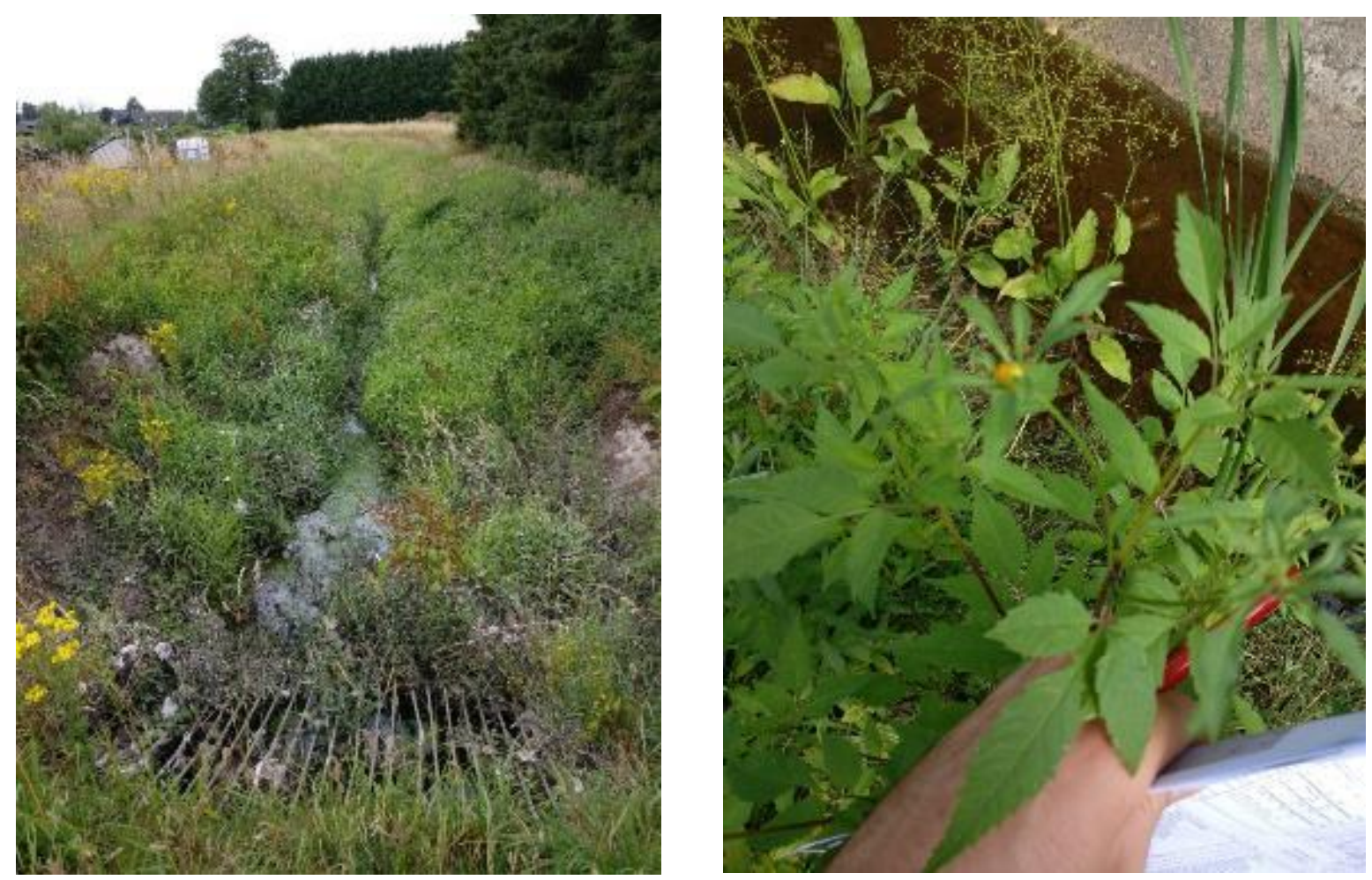

Vegetatieopname bij een overstortsloot. 


\section{Resultaten}

Er zijn gedurende 3 jaar macrofyten geïnventariseerd in overstortsloten in het beheergebied van Waterschap de Dommel. Dit geeft een beeld van de ecologische kwaliteit bij de overstorten. Grofweg kunnen we constateren dat van de 200 overstortsloten de $50 \%$ niet te inventariseren was i.v.m. maaiwerkzaamheden of droogte en dat $25 \%$ voldeed aan de EKR score. $25 \%$ van voldeed niet of het ene jaar wel, het andere jaar niet.

\section{Dood hout inbreng Tongelreep (en/of Beekloop)}

\section{Setting}

De Tongelreep (R5 langzaam stromende middenloop /beek op zand) en heeft vanaf SGBP2 als enige beek in beheersgebied van waterschap De Dommel de status Natuurlijk.

\section{Doel}

Laatste knelpunten op gebied van inrichting en waterkwaliteit aanpakken. In de Tongelreep zijn vanaf begin jaren '90 (Achelse Kluis) tot en met 2017 veel herinrichtingsprojecten uitgevoerd (Valkenhorst ter hoogte van viskwekerij totaal $8 \mathrm{~km}$ ) en vispassages aangelegd, waardoor de beek nagenoeg hydromorfologisch op orde is. Door het inbrengen van dood hout verwachten we een extra impuls wat betreft variatie van bodemsubstraten en variatie in stroomsnelheden.

\section{Streefbeeld}

Halen van ecologische doelen KRW in 2021.

\section{Aanpak en tijdslijn}

In 2012 zijn patches met dood hout ingebracht (gestandaardiseerd volgens landelijk protocol); en is meerdere jaren bemonsterd door Alterra en het waterschap op verschillende biologische parameters.

\section{Resultaten}

Al na een paar jaar bleek inderdaad dat door inbreng van hout de stromingscondities en habitatvariaties verbeterd waren met als gevolg meer individuen (macrofauna), maar ook de vestigingsplaats van vlottende waterranonkel (door hardere stroming). Ook is intern het gesprek op gang gekomen hoe het beheer van een natuurlijke beek eruit kan zien (met afdeling beheer en onderhoud en adviseurs). 


\section{Projecten waterschap Amstel, Gooi en Vecht}

Aangeleverd door Winnie Rip.

\section{De Vecht}

\section{Setting}

De Vecht, een oude tak van de Rijn tussen Utrecht en Muiden, is tegenwoordig een stilstaand boezemwater, van het type M7b (groot diep kanaal met scheepvaart).

\section{Doel}

De Vecht was een sterk verontreinigd water met steile oevers, veel woonboten en veel recreatievaart. Illegaal aanleggen in kwetsbare groene oevers en daarmee gepaard gaande verspreiding van afval was een probleem. In 1996 is de uitvoering van het Restauratieplan Vecht (RPV) gestart, waaraan alle Vechtgemeenten, RWS, de provincies en waterschappen hebben meegedaan. De doelen van het RPV sluiten naadloos aan op de doelen van de KRW. Na afronding van het RPV is het waterschap door gegaan met maatregelen om de ecologische kwaliteit verder te versterken.

\section{Streefbeeld}

Voor 2027 moeten de KRW-doelen zijn gehaald. Het water is dan helder, er groeien waterplanten in de oever en luwe delen en circa $50 \%$ van de oevers is natuurvriendelijk. De macrofauna en visstand is gevarieerd. De doelsoorten van het RPV (Ringslang, IJsvogel en Snoek) komen algemeen voor.

\section{Aanpak en tijdslijn}

Van 1997 tot 2015 is ruim $12 \mathrm{~km}$ natuurvriendelijke oevers aangelegd. Woonboten op voor de natuur, landschap en cultuurhistorisch kwetsbare locaties zijn verplaatst. Er zijn afspraken gemaakt om verdere toename van woonschepen en meer bebouwing langs de Vecht te voorkomen. Voor recreatievaart zijn ongeveer 150 openbare ligplaatsen in het buitengebied gerealiseerd. Er is geïnvesteerd in de realisatie van een kanoroute en in ijsvogelwanden. De maximum vaarsnelheid is aangepast naar 9 en $6 \mathrm{~km} / \mathrm{h}$. Op twee locaties zijn milieuservicepunten ingericht, waar boten vuil water kunnen inleveren. Twee rioolwaterzuiveringsinstallaties zijn/worden gerenoveerd (Horstermeer in 2012 en Utrecht in 2019). Tussen 2010 en 2015 is de zwaar verontreinigde waterbodem over de gehele lengte van de Vecht (42 $\mathrm{km}$ ) gesaneerd.

\section{Resultaten}

De abiotische randvoorwaarden zijn sterk verbeterd. Het doorzicht is op sommige plaatsen toegenomen van 0,4 naar 1,5 m. Het fosfaatgehalte (P-tot) is gedaald van 0,8 in de jaren 90 naar 0,2 in 2018. Plaatselijk worden er zelfs concentraties gemeten van onder de $0,1 \mathrm{mg} \mathrm{P} / \mathrm{l}$.

Op veel plaatsen groeit het riet weer in het water en zijn daarmee het aantal paaiplaatsen voor vis sterk toegenomen.

Het KRW-doel voor fytoplankton wordt sinds 2010 ruimschoots gehaald. De score voor overige waterflora nog niet en vissen weer wel. Macrofauna geeft geen eenduidig beeld te zien over de jaren.

De grote baggeroperatie in de Vecht heeft, behalve tot een sterke waterkwaliteitsverbetering, tot positieve neveneffecten geleid. Interessante archeologische vondsten leverden een nieuwe bijdrage aan de kennis over de historie van de Vecht en haar buitenplaatsen.

De landschapsbeleving is sterk verbeterd door de aanleg van een kanoroute, het herstel van jaagpaden en dakpannenbeschoeiingen en het verplaatsen van woonboten waardoor vrij zicht kwam op historische gebouwen. 


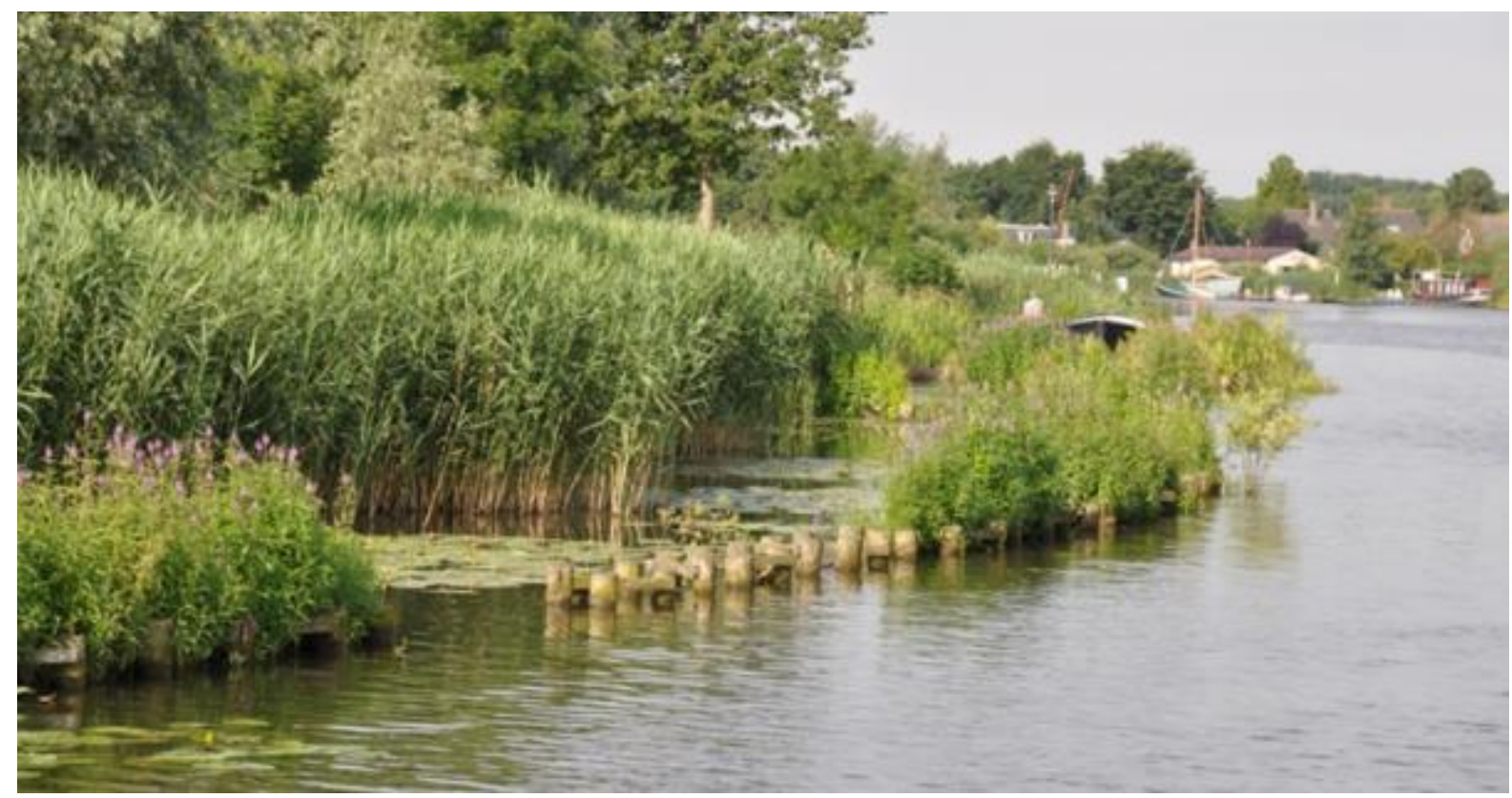

De Vecht.

\section{Oxidatie van het hypolimnion als defosfateringssysteem in de Ouderkerkerplas}

\section{Setting}

De Ouderkerkerplas is een zandwinput, 40 jaar geleden aangelegd t.b.v. zandwinning voor de aanleg van de A9. De plas heeft een natuurfunctie en een recreatiefunctie. Beide functies zijn afhankelijk van een goede waterkwaliteit. De bodem in de diepe plas is fosfaat rijk. De fosfaten in de bodem komen vrij onder zuurstofarme omstandigheden. Sinds het begin van de jaren negentig zijn de fosfaatgehalten in het water langzaam gestegen en is er een groeiend algenprobleem ontstaan.

De plas is aangewezen als KRW waterlichaam, maar voldoet niet aan de KRW-doelstellingen. Huidige toestand wordt als slecht beoordeeld: te hoge fosfaatbelasting, stikstof, te laag doorzicht als gevolg van algenbloei. Een lange periode in de zomer was de plas gesloten door aanwezigheid blauwalgen. De waterkwaliteitsdoelstellingen vanuit de Europese Kaderrichtlijn Water (KRW) maken het zoeken naar vernieuwende oplossingen urgent.

In 2007 klopte Nuon aan bij het waterschap met het plan om koude te gaan winnen. Het water onder in de diepe plas heeft door de thermische stratificatie tijdens voorjaar, zomer en najaar een constante temperatuur tussen de 4 en $7^{\circ} \mathrm{C}$. Hiermee kunnen bedrijfsgebouwen worden gekoeld. Als alternatief voor de traditionele, individuele koelmachines zorgt dit collectieve systeem voor energiebesparing en verlaging van $\mathrm{CO}_{2}$-uitstoot (circa 75 procent reductie).

$\mathrm{Na}$ het koelproces wordt het gebruikte water boven in de plas teruggebracht. Om te voorkomen dat deze activiteit de waterkwaliteit in de Ouderkerkerplas verslechtert, stelt Waternet eisen aan deze lozing, bijvoorbeeld aan de maximale fosfaatvracht. Om aan de normen te voldoen heeft Nuon in goed overleg met Waternet een innovatief zuurstof toevoer-systeem aangelegd op de bodem van de plas.

Het zuurstof zorgt ervoor dat fosfaat zich aan de bodem bindt door oxidatie van gereduceerd ijzer, waardoor dit samen met fosfaat neerslaat. Dit is voor het eerst dat deze techniek voor deze situatie wordt toegepast. 


\section{Doel}

Een uniek project waar publieke en private partijen samenwerken aan een potentiële win-win-winsituatie: 1 . reductie van CO2-uitstoot, 2 . verbetering van de waterkwaliteit en 3 . ontwikkeling kennis over de toepassingsmogelijkheid van een nieuw wapen in de strijd tegen algenbloei.

\section{Aanpak}

Voor de oxidatie van het hypolimnion is door Nuon een oxidatiesysteem aangelegd. Vanaf de zuurstoftank loopt een leiding naar de bodem van de Ouderkerkerplas. Het oxidatiesysteem is op 15 maart 2010 in werking gesteld op $100 \mathrm{~kg} \mathrm{O} / \mathrm{dag}$. Onttrekking van het koude water vindt plaats op $40 \mathrm{~m}$ diepte en de uitlaat van het opgewarmde water lag gedurende het eerste jaar (2010) op 14 m diepte. Begin 2011 werd de uitlaat naar boven verplaatst ( $2 \mathrm{~m}$ diepte) en vanaf april 2011 wordt het koude water op het epilimnion geloosd. In 2011 en 2012 zijn er veel problemen geweest met het oxidatiesysteem en heeft het systeem ook tijdelijk helemaal niet gefunctioneerd. Begin oktober 2012 is het gehele oxidatiesysteem vervangen door een nieuw systeem. Daarna zijn er tot en met december 2017 geen grote technische problemen meer geweest.

De eerste jaren (2010-2012) werd in principe een constante hoeveelheid van $10 \mathrm{~kg} \mathrm{O} /$ uur gedoseerd. In de zomer 2013 namen de zuurstofconcentraties in de plas te snel af, waardoor de dosering vanaf augustus 2013 trapsgewijs werd verhoogd tot $20 \mathrm{~kg} / \mathrm{uur}$ (maximale dosering) om het toenemende zuurstofverbruik in de plas te compenseren. In de zomer en het najaar neemt namelijk als gevolg van de afbraak van afgestorven algen het zuurstofverbruik in de plas toe. Uiteindelijk werd tot het volgende doseringsschema besloten: januari tot begin mei $5 \mathrm{~kg} \mathrm{O} / \mathrm{uur}$, begin mei tot begin september $10 \mathrm{~kg}$

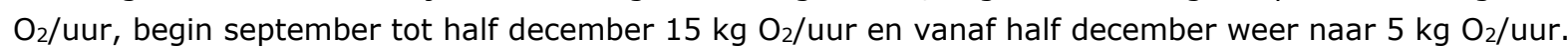
Dit doseringsschema werd gehanteerd in de jaren 2014 t/m 2017.

\section{Resultaten}

$\mathrm{Er}$ is een afname opgetreden in totaal-P en chlorofyl-a en een toename in het doorzicht sinds het systeem goed functioneerde. In 2016 was er geen vegetatie aanwezig in de plas. In 2018 werd een kranswierveld gevonden van 35 bij 15 m met Chara globularis en C. virgata. Daarnaast vonden duikers op 8 meter diepte planten van Myriophyllum spicatum en Potamogeton perfoliatius. Het doorzicht betrof op dat moment 5,5 m.

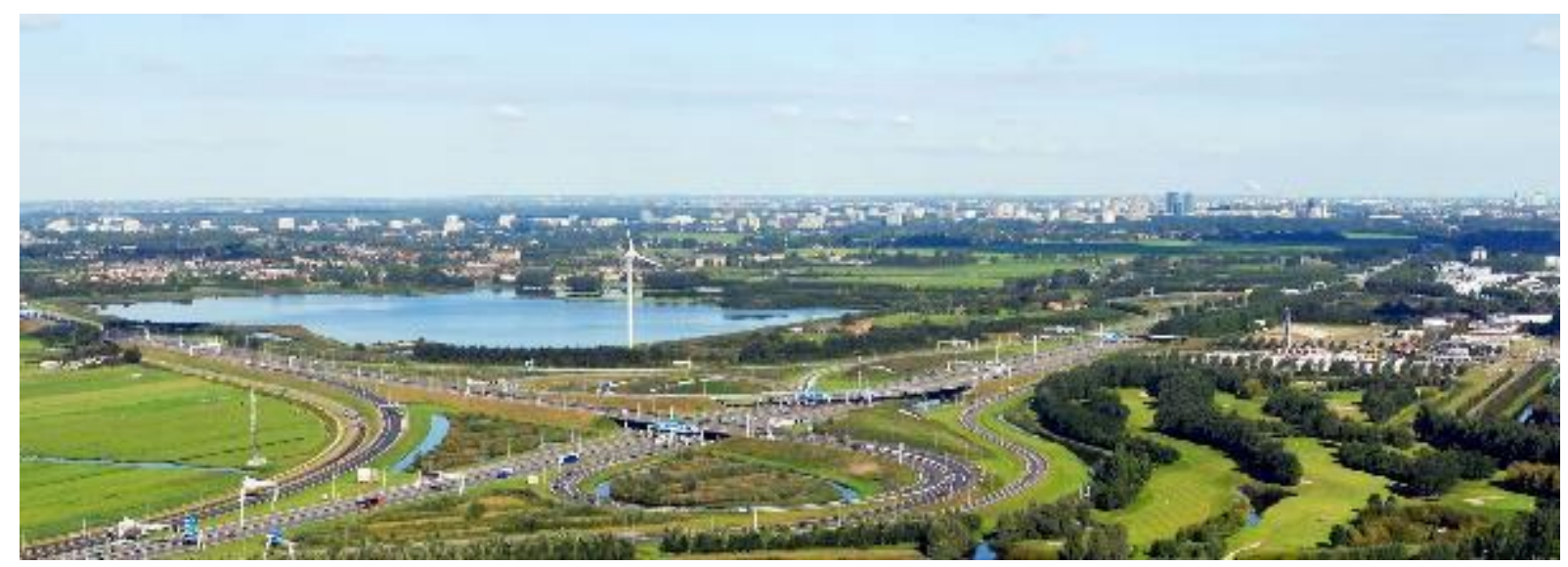

De Oudekerkerplas. 


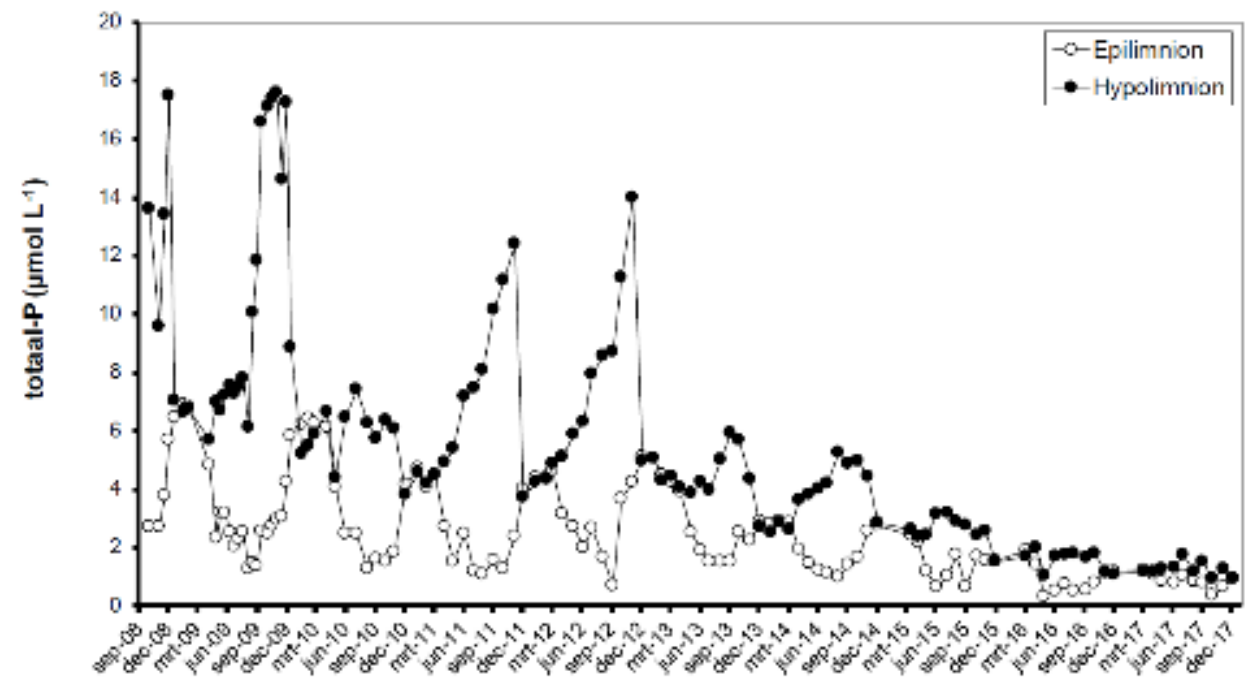

Figuur 3.9. Verloop van de concentratie totaal- $P$ in het epilimnion $(2 \mathrm{~m}$ diepte) en hypolimnion (35-36 $\mathrm{m}$ diepte) in de periode 2008-2017.

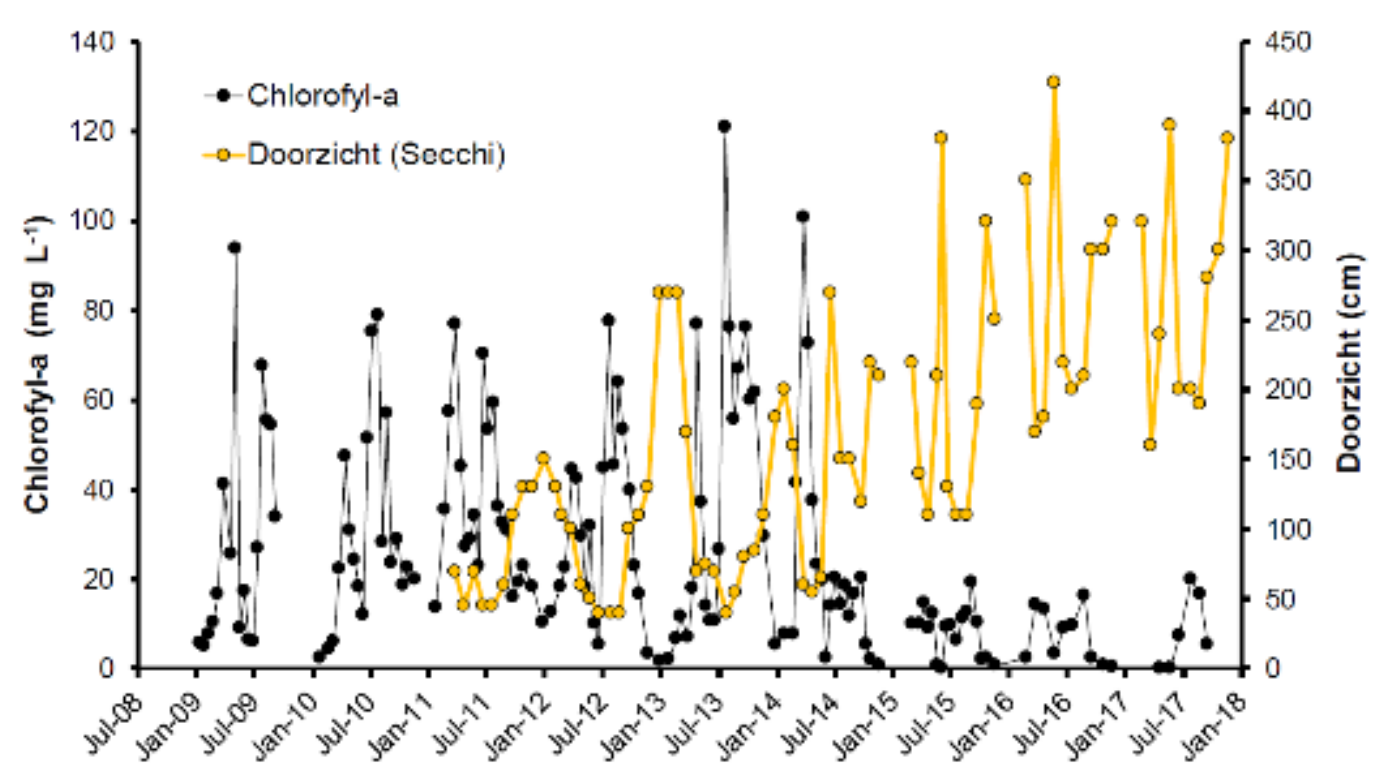

Figuur 3.13. Verloop van de concentratie chlorofyl-a (in mg L $\mathrm{L}^{-1} ; \mathrm{t} / \mathrm{m} 2016$ ) en het doorzicht (in cm) van de plas in de periode $2008 \mathrm{t} / \mathrm{m} 2017$.

Concentraties totaal-P en chlorofyl-a en doorzicht in de Ouderkerkerplas. Sinds 2013 wordt met een vast doseringschema gewerkt. 


\section{Projecten waterschap Vallei en Veluwe}

Aangeleverd door Maarten Veldhuis.

\section{Gecombineerd ecologische en cultuurhistorisch herstel sprengenstelsel Vaassense beken}

\section{Setting}

Uitgezonderd de Dorpse Beek zijn alle beken van sprengenstelsel Vaassense beken aangewezen als HENwater (water van het Hoogste Ecologische Niveau). Het zijn bijna alle typische sprengenbeken en een enkele is meer te typeren als een laaglandbeek.

\section{Doel}

De doelstelling van het Raamplan Vaassense Beken betreft het inrichten en onderhouden van het bekencluster Vaassense Beken, waarbij de kernkwaliteiten van dit gebied behouden blijven en op een kosteneffectieve wijze, waar mogelijk worden versterkt.

\section{Streefbeeld}

Omdat natuurlijke beken van bovenloop via middenloop naar benedenloop van karakter veranderen, zijn voor de Vaassense Beken drie zones gehanteerd. Bij de zones zijn passende streefbeelden gekozen:

1. Zone I omvat de sprengen in de bossen op de rand van de stuwwal. Het best passende streefbeeld is Sb, sprengen en bovenloopjes van sprengenbeken, en voor de Egelbeek Bb, bronnen en bovenloopjes van bronbeken;

2. Zone II ligt meer benedenstrooms op de helling van de stuwwal. Het best passende streefbeeld is $B o B$ na $B$, natuurlijke bovenlopen;

3. Zone III ligt nog verder stroomafwaarts, tegen de Grift aan. Hier vinden we de benedenlopen van de Hartense Molenbeek, de Rode beek en de Dorpse Beek. Het best passende streefbeeld is Bo B hn B, halfnatuurlijke bovenlopen.

\section{Aanpak en tijdslijn}

Het verbeteren van de 5-S-en is in grote mate gebruikt om de knelpunten en maatregelen te bepalen. Onder andere de volgende maatregelen zijn gebruikt, waarbij behoud van de cultuurhistorische waarde belangrijk was:

- $\quad$ Stimulering micromeandering;

- Het toepassen van beekvernauwing;

- Passief beheren/pleksgewijs ruimen (takken/blad deels laten liggen);

- Aanbrengen van obstakels;

- Saneren riooloverstorten (taak gemeente);

- Knelpunten migreerbaar maken via al aanwezige kortsluitingen, omleidingen of A-wateren;

- Aanleggen van een vispassages;

- Habitat verbeteren van de elrits en de rivierdonderpad;

- Oplossen interne migratiebarrières;

- Bomen met overhangende takken dicht langs beken laten staan;

- Wortelkluiten van omgevallen bomen laten liggen (natuurlijk bosbeheer);

- Het aanleggen van een ijsvogelwal;

- Molenplaatsen, wijerds, aflaten en opgeleide trajecten zoveel mogelijk duurzaam herstellen;

- Herkenbaarheid vergroten door het plaatsen van informatieborden op karakteristieke locaties. 
Het beekherstel van de Vaassense Beken heeft plaatsgevonden in de periode van $2008 \mathrm{t} / \mathrm{m} 2011$. Het beekherstel heeft plaatsgevonden in de vorm van interactieve uitvoering, waarbij de omgeving nauw betrokken is geweest bij invulling van de plannen. Een specifiek onderdeel van het beekherstel vormde het saneren van de Hartense Molenbeek. Hierbij zijn, naast alle herstelmaatregelen, ook alle ecologische risico's van de historische verontreiniging in waterbodem en oever weggenomen. In het kader van dit deelproject is ook de molengoot van de Canneburgher molen gerenoveerd.

\section{Resultaten}

Uit evaluatieonderzoek van de sanering is gebleken dat er geen restrisico's meer zijn voor ecologie. Ecologie: weinig of geen specifieke monitoring in het kader van het project, resultaten vooralsnog onbekend (mogelijk nog wel gegevens beschikbaar). De Egelbeek is deels wel gemonitord, maar is mogelijk geen onderdeel van project Vaassense Beken.

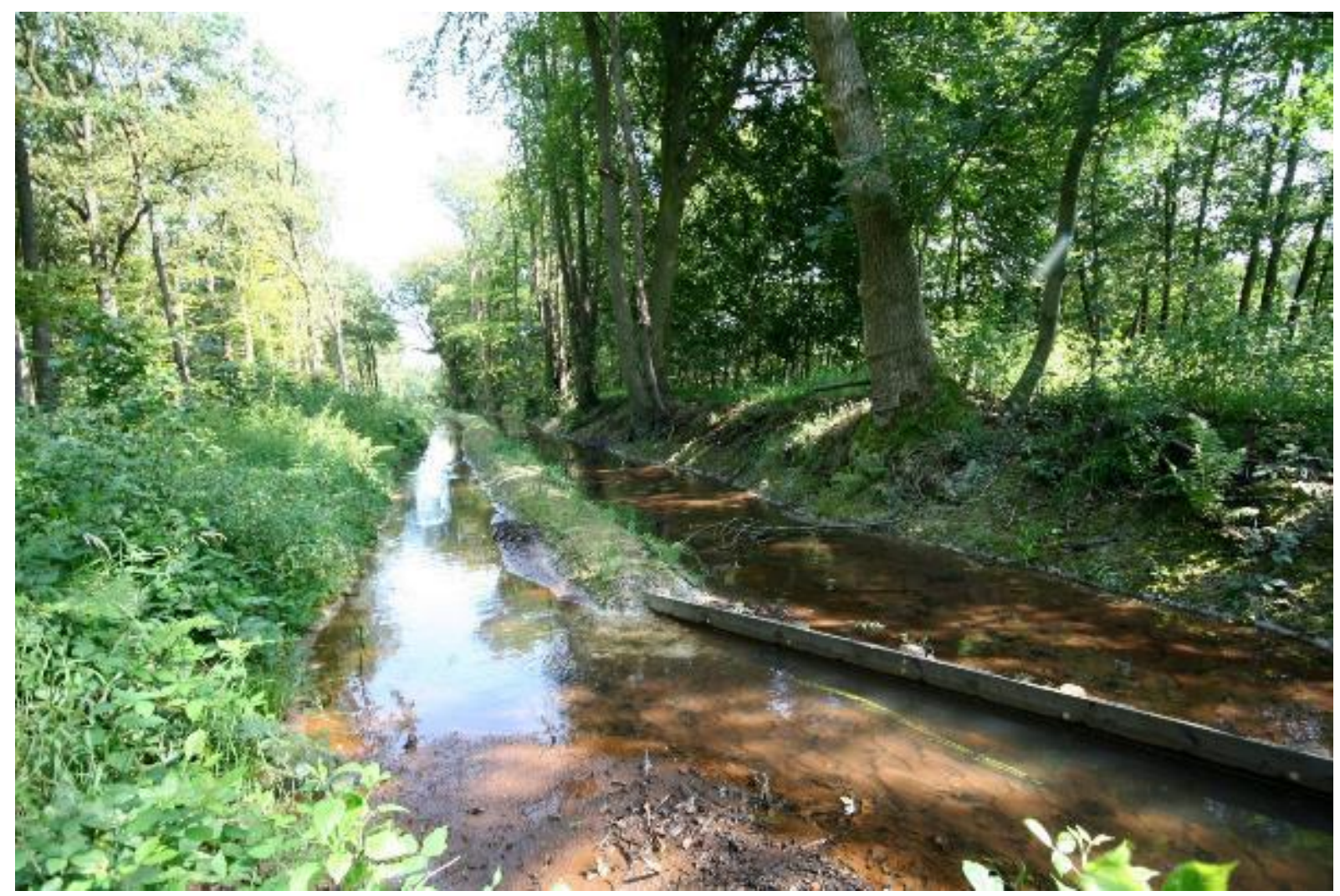

Vaassense beken

\section{Aanleg beekbegeleidende zone Modderbeek}

\section{Setting}

De Modderbeek is een laaglandbeek in de Gelderse Vallei. Watertype: KRW-type R5.

\section{Doel}

Tweeledig: KRW (waterschap) en EVZ (provincie Utrecht).

\section{Streefbeeld}

Een beek die vrij meandert (natuurlijk verloop), zonder obstakels, in een 40 meter brede strook. De beekzone is voor 50 tot 100 procent is beschaduwd door krooncontact (geen dichte ondergroei); deze is 
onderhoudsvrij. Verder ligt deze beekzone zone verdiept in het landschap, waardoor er veel water kan worden geborgen tijdens piekafvoeren. Tenslotte is er een grote diversiteit in bodem, oever, substraat en profiel.

\section{Aanpak en tijdslijn}

Voorafgaand aan de uitvoering heeft er een grote vrijwillige kavelruil plaatsgevonden om beschikbare grond binnen een aaneengesloten 40 meter brede strook te krijgen over een lengte van $6 \mathrm{~km}$. Vervolgens is de uitvoering in oktober 2015 gestart in september 2016 opgeleverd. De uitvoering bestond uit realisatie van de beekzone maar ook uit kavelwerken n.a.v. de kavelruil. Van de $165.000 \mathrm{~m} 3$ grond die ontgraven is, is $100.000 \mathrm{~m} 3$ verwerkt op agrarische percelen.

\section{Resultaat}

Het resultaat is een prachtige beekzone die nu volop in ontwikkeling is en een omgeving die erg tevreden is over aanpak en uitvoering en resultaat. Ecologie: uit visstandonderzoek voor de KRW in 2017 blijkt dat de Modderbeek op de KRW-maatlat voor vis ontoereikend scoort. Dat komt omdat de beek relatief soortenarm is, het aantal stromingsminnende vissoorten gering is, en migrerende soorten afwezig zijn (beek is dan ook niet optrekbaar vanuit Valleikanaal). Dit heeft deels te maken met het ondiepe karakter van de beek na herinrichting, maar mogelijk heeft het systeem nog wat meer tijd nodig om zich na de herinrichting verder te ontwikkelen; de situatie in 2017 is te beschouwen als een pioniersituatie.

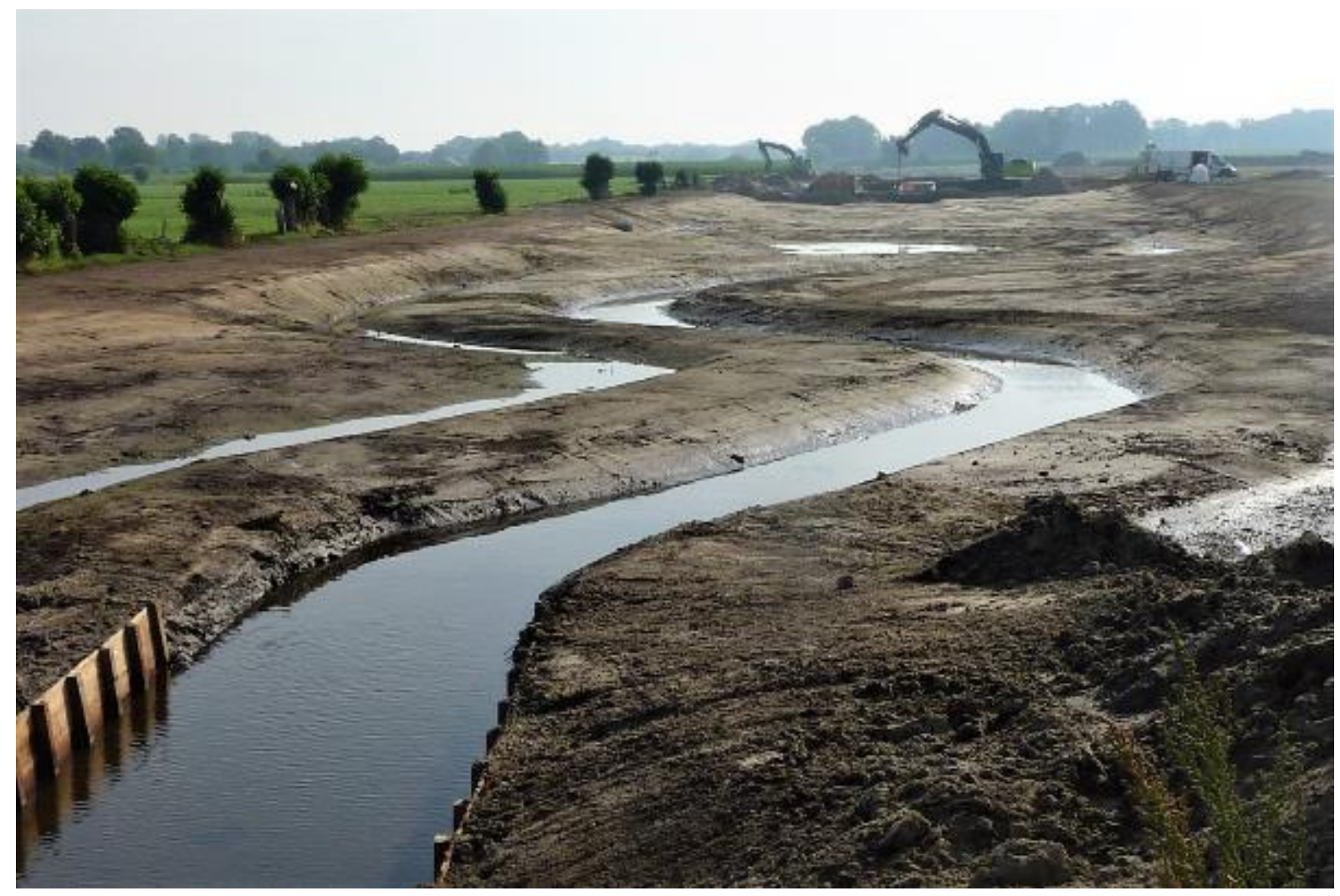

Herinrichting Modderbeek.

\section{Synergieproject Impuls Hierdense Beek}

\section{Setting}


Synergieproject vanuit KRW, waarin KRW-doelen, provinciale HEN-doelen, Natura 2000-doelen (N2000gebied Veluwe), antiverdrogingsdoelen en GNN-doelen worden gerealiseerd. Knelpunten waren/zijn: te diepe insnijding, relatie beek en beekdal niet goed ontwikkeld, waterkwaliteit nog niet op orde (te hoge $\mathrm{N}$-gehalten), piekafvoeren uit bovenstrooms landbouwgebied, te weinig variatie in stroming, structuren en substraten, droogval van trajecten.

\section{Doel}

Aanpakken knelpunten die natuurlijk functioneren in de weg staan.

\section{Streefbeeld}

Voor het traject Leuvenumse Beek wordt gestreefd naar een zo natuurlijk mogelijk functionerende laaglandbeek, waarbij de relatie tussen beek en omgeving (beekdal) is hersteld en er ecologisch waardevolle gradiënten zijn ontwikkeld.

\section{Aanpak en tijdslijn}

$\mathrm{Er}$ is een serie maatregelen uitgevoerd in de Leuvenumse beek. In 2011 is een pilot dood hout gestart in het kader van KRW-innovatieprojecten, waarbij dood hout pakketten zijn ingebracht op een groot aantal punten. In 2013-2014 zijn verschillende inrichtingsmaatregelen genomen: aantakken oude beeklopen, aanbrengen houtpakketten, houtdrempels en zandinbreng en herstel kwelgebied bij Rode Spreng. Momenteel vindt het vervolg van de zandinbreng plaats. De herstelmaatregelen worden sinds de start van de uitvoering gemonitord.

\section{Resultaten}

Er zijn veel successen geboekt de afgelopen jaren:

- Veel meer variatie in stroming, structuren en substraten door houtinbreng en zandinbreng;

- Over een substantiële lengte een ondiepere beek die veel meer relatie heeft met omgeving door o.a. frequente inundaties van aangetakte laagten en beekmoerassen bij piekafvoeren;

- Grootschalige buffering water in voormalige beekdalgraslanden en omliggende bosgebieden waardoor sterke demping en enige vertraging van piekafvoeren optreedt (met name benedenstrooms van A28);

- Snelle herkolonisatie door macrofauna (karakteristieke beeksoorten) vanuit bovenstroomse trajecten van zandafzettingen a.g.v. zandinbreng (onderzoek Ralf Verdonschot);

- Snelle herkolonisatie door macrofauna (karakteristieke beeksoorten) vanuit bovenstroomse trajecten in opnieuw aangetakte oude beeklopen (onderzoek Judith Westveer);

- Lokaal sterfte van vernattingsgevoelige boomsoorten in beekdal door frequentere en soms langdurige inundaties; daardoor meer open (minder beschaduwde) plekken langs beek en ontwikkeling kruidlaag met lichtminnende vegetaties (met o.a. moeras-, bos-, en ruderale plantensoorten);

- In beekmoerassen grote diversiteit aan ongewervelden aanwezig (fauna-hotspot);

- Vernatting kwelgebied rond voormalige Rode Spreng;

- Stagnerende (langzaam stromende) trajecten ontstaan direct bovenstrooms van houtdrempelsen pakketten; hier echter toch nog stromingsminnende macrofauna aanwezig;

- Geen toename bovenstroomse wateroverlast buiten natuurgebied. 

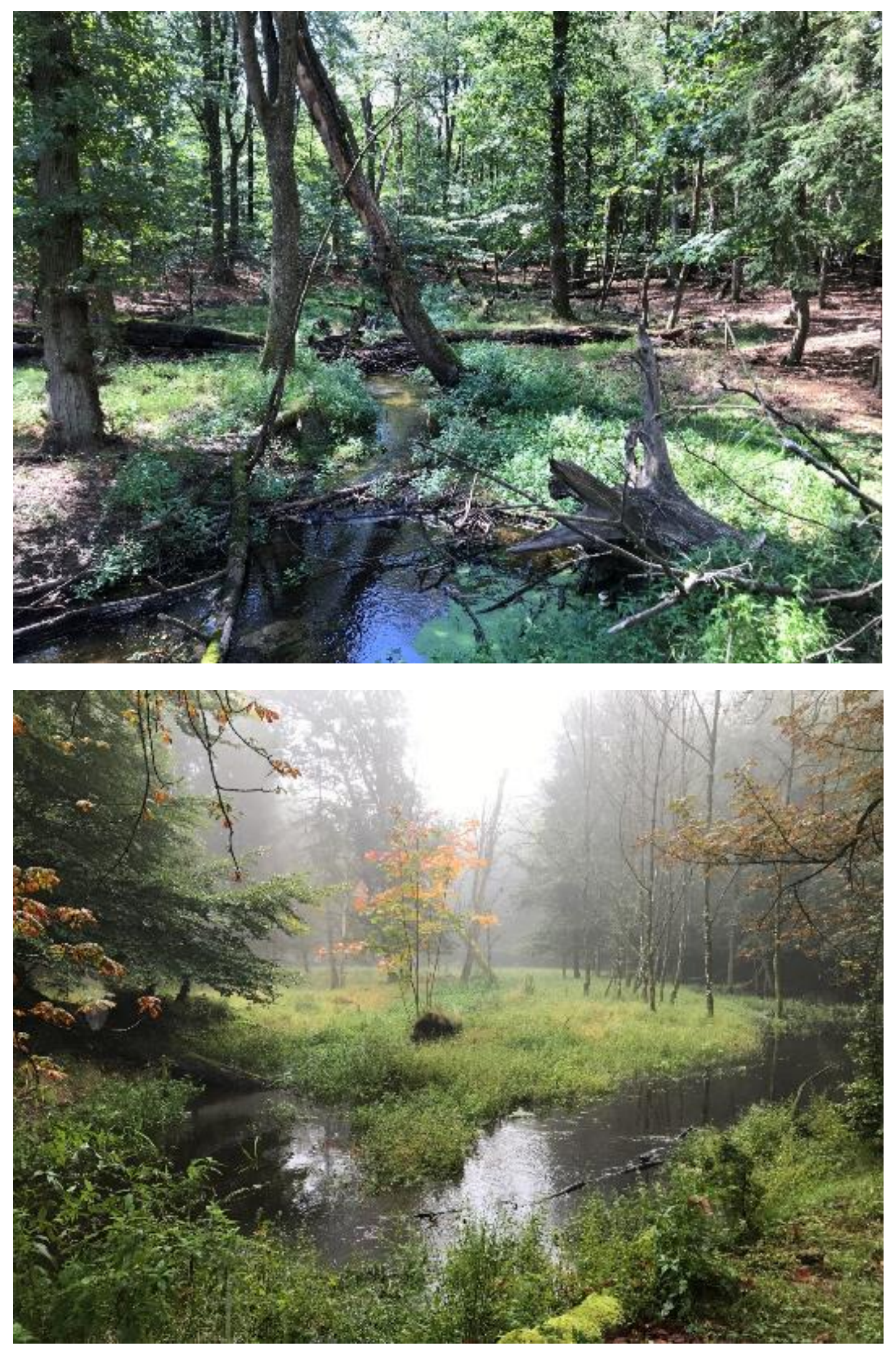

Herstelde trajecten Leuvenumse beek. 


\section{Projecten waterschap Scheldestromen}

Aangeleverd door Marius van Wingerden.

\section{Vispassages}

\section{Setting}

De wateren in Zeeland zijn vaak brak, soms wat zoeter of licht brak. Typische vissen die goed gedijen in deze wateren zijn soorten die goed tegen het brakke water kunnen. Deze vissoorten hebben in hun levenscyclus fases waarin zij in het brakke polderwater leven, maar ook in de zee of het estuarium, in ons geval de Westerschelde of Oosterschelde. Omdat we deze soorten in ons watersysteem willen hebben, is het dus essentieel om vispassages aan te leggen tussen het zoute buitenwater en ons polderwater.

\section{Doel}

Verbeteren uitwisseling vis binnen- en buitenwateren.

\section{Aanpak en tijdslijn}

We zijn nu ong. 10 jaar bezig met het aanleggen van vispassages. Tot 2027 blijven we daarmee bezig en leggen we totaal ruim 40 vispassages aan. Dit zijn passages tussen binnen en buitenwater maar het merendeel betreft passages tussen peilgebieden binnendijks.

\section{Resultaten}

We zien hierdoor de visstand verbeteren. Soorten als driedoornige stekelbaars, brakwatergrondel, glasaal/paling en bot komen massaal binnen.

\section{Natuurvriendelijke oevers}

Om de morfologie in de waterlopen te verbeteren leggen we natuurvriendelijke oevers aan. Deze oevers bieden ook een goed habitat voor macrofauna en vis (schuilen, paaien, foerageren). Ook zouden de oevers een positief effect moeten hebben op het reduceren van drift van bestrijdingsmiddelen uit de landbouw en op het onttrekken van voedingsstoffen uit het water. De bedoelde effecten van natuurvriendelijke oevers zijn echter moeilijk te monitoren. Tot op heden kunnen we niet goed aangeven hoeveel effect de oevers hebben op de waterkwaliteit, dit omdat het effect minder 'zwart/wit' is als bijvoorbeeld bij vispassages, waarbij soorten het systeem in komen, welke er in eerste instantie niet waren.

\section{Toekomstige aanpak}

\section{Setting}

We willen weten in hoeverre onze watersystemen voldoende zijn ingericht voor de doelsoorten of dat er misschien nog maatregelen nodig zijn.

\section{Doel}

Voor de brakke wateren brengen we daarvoor in kaart welke soorten te verwachten zijn in het water.

\section{Aanpak}


Per soort wordt er een uitgebreide beschrijving gemaakt van wat deze soort nodig heeft van zijn omgeving op het gebied van inrichting/morfologie (verschillende soorten habitat voor verschillende levensstadia). Dit wordt daarna samengevat en zou duidelijkheid moeten geven in hoeverre onze watersystemen voldoende zijn ingericht voor de doelsoorten of dat er misschien nog maatregelen nodig zijn.

\section{Resultaten}

Nog geen. 


\section{Projecten waterschap Brabantse Delta}

Aangeleverd door Marco Beers.

\section{Boven Donge - meander Leijkant}

\section{Setting}

De Boven Donge is voor de KRW getypeerd als langzaam stromend bovenloopje op zand. Deze bovenloop van $22 \mathrm{~km}$ lengte ontspringt in Baarle-Nassau en is bovenstrooms te kenmerken als doorstroommoeras. Verder benedenstrooms in de beek, mede door normalisaties duidelijker als waterloop in het landschap herkenbaar. In de huidige situatie watert de beek ten westen van Tilburg af op het Wilhelminakanaal, terwijl de beek voor de jaren tachtig van de vorige eeuw overging in de Beneden Donge die toen nog in de Bergsche Maas uitmondde.

\section{Doel}

Het project is uitgevoerd om stroming te herstellen en een vismigratieknelpunt (stuw) op te lossen.

\section{Streefbeeld}

Alle vismigratieknelpunten zijn op een zo natuurlijk mogelijke manier opgelost, bij voorkeur door de barrières te verwijderen of met een nevengeul te passeren, zodat er ook een bijdrage wordt geleverd aan het herstel van stroming. De stroming wordt verder hersteld door het profiel van overgedimensioneerde trajecten te versmallen. Daarnaast worden bufferzones langs de beek natuurlijker ingericht.

\section{Aanpak en tijdslijn}

In 2013 is tussen het plaatsje Riel en de snelweg A58 een nieuwe geul met een smal profiel gegraven als omleiding om stuw Zandeind en zijn de aanliggende percelen ingericht als ecologische verbindingszone. De oude, genormaliseerde loop is afgedamd om het water door de nieuwe meander te sturen. De oude loop is in stand gehouden om bij extreme regenval extra afvoercapaciteit te hebben om wateroverlast te voorkomen. De maatregelen zijn mede op initiatief van de eigenaar van landgoed Leijkant uitgevoerd.

\section{Resultaten}

Helaas is er geen nulmeting gedaan. De meander ontwikkelt zich op het oog goed. In tegenstelling tot in de oude loop is er ook bij lage afvoeren nog stroming zichtbaar, zijn er verschillende substraten aanwezig en vormen zich in het zand stromingsribbels. In 2015 is de visstand in de meander bemonsterd. In vergelijking met de andere trajecten die in de beek zijn bemonsterd, zijn er veel vissen en soorten gevangen. Het aantalsaandeel aan stromingsminnende soorten (bermpje en riviergrondel) is met bijna 95\% veel hoger dan op de andere bemonsterde trajecten. 


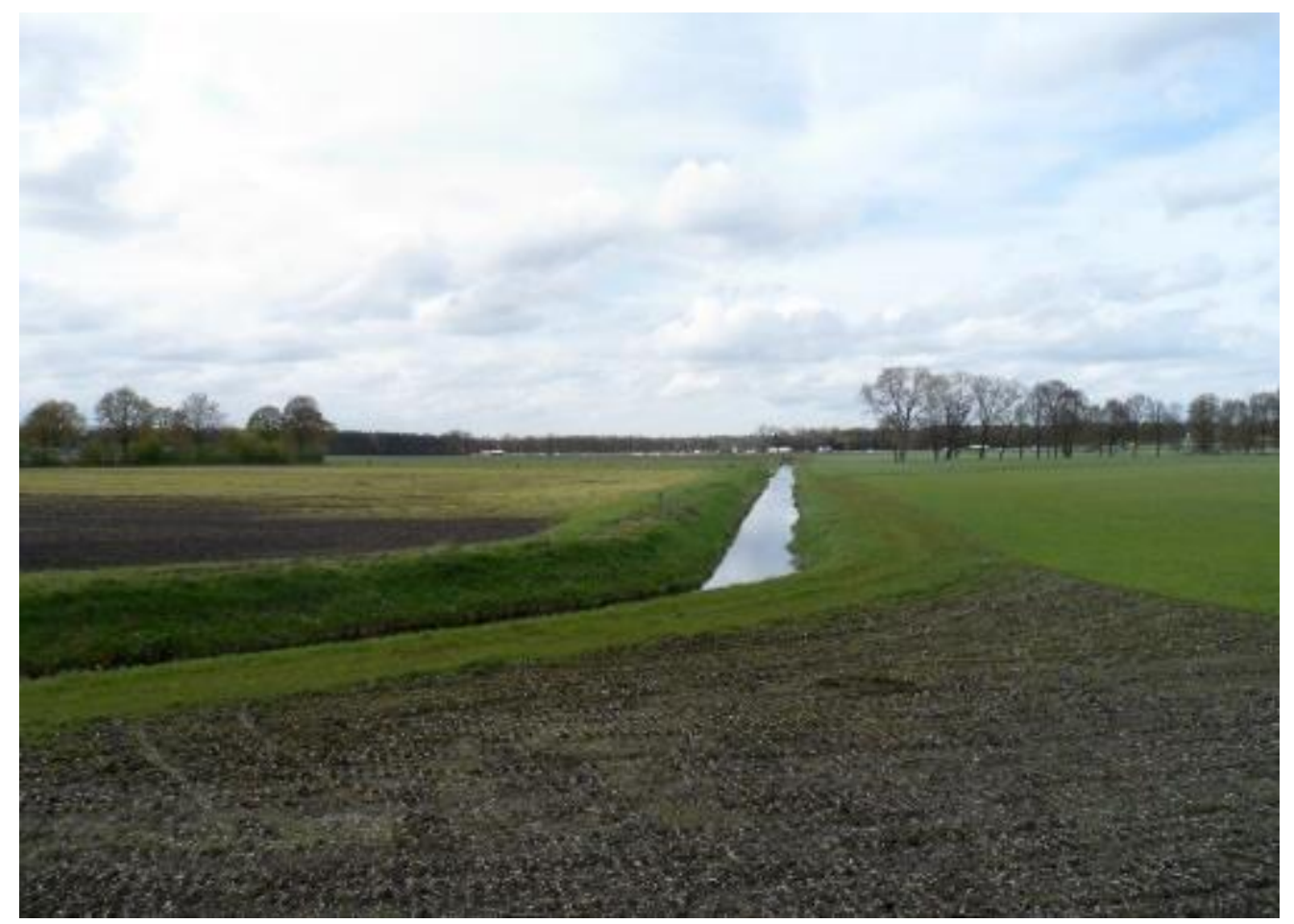

Oude loop voorafgaand aan maatregelen.

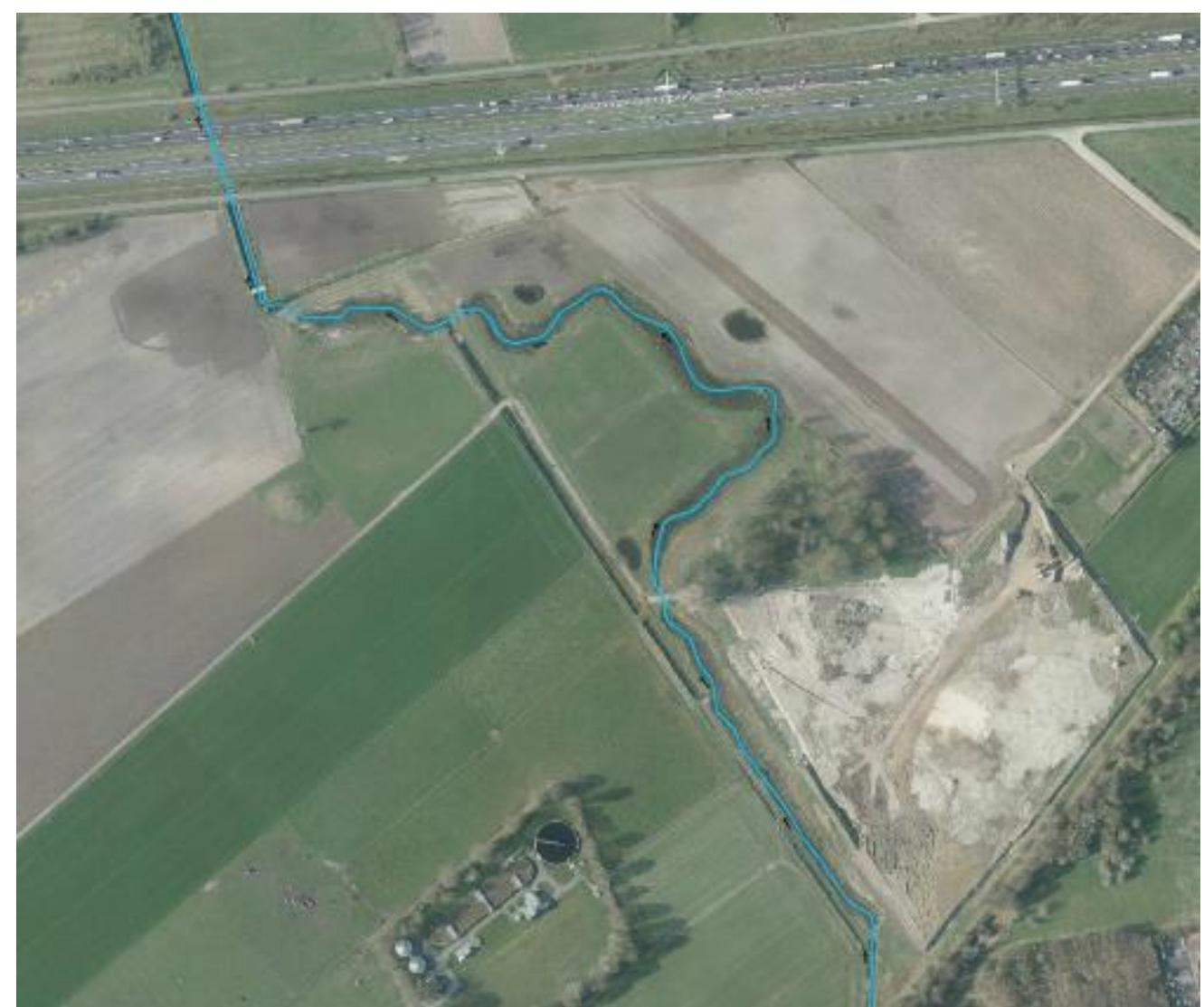

Nieuwe gegraven meander (blauwe lijn) met aan de westzijde de genormaliseerde oude loop 


\section{Binnenschelde - snoekpaaigebied}

\section{Setting}

De Binnenschelde is een plas van circa 180 ha aan de westzijde van Bergen op Zoom. De plas is in 1984 ontstaan door de aanleg van de Markiezaatsdam als onderdeel van de deltawerken. Vanaf 1988 is zoet water vanuit het Zoommeer ingelaten en ontstond de plas (daarvoor lag de Binnenschelde droog). Voor de KRW is de Binnenschelde getypeerd als M30, zwak brak water. De plas heeft ook een recreatieve functie en is aangewezen als zwemwater.

\section{Doel}

$\mathrm{Na}$ het ontstaan is de Binnenschelde door inlaat van water gestadig verzoet. Vanaf begin jaren negentig was de plas helder met een lage visbezetting, maar in de loop van de jaren negentig werd de plas troebel en vervolgens nam de hoeveelheid vis steeds verder toe. Om te voorkomen dat de plas zou veranderen in een stabiel troebel systeem met dominantie van brasem is een paaigebied voor snoek aangelegd. Dde bedoeling was dat jonge snoek uit het paaigebied de toename van witvis in de Binnenschelde beperkt en op die wijze zorgt voor een helder systeem met verschillende soorten ondergedoken waterplanten.

\section{Streefbeeld}

Voor de Binnenschelde wordt gestreefd naar helder water met een diverse begroeiing van verschillende soorten ondergedoken waterplanten met tevens goede mogelijkheden voor recreatie.

\section{Aanpak en tijdslijn}

Het snoekpaaigebied is in 1997 gerealiseerd. De eerste jaren na de aanleg zijn in het begin van het voorjaar in de Binnenschelde geslachtsrijpe snoeken gevangen en in het paaigebied uitgezet om de paai van snoek in het nieuwe gebied te stimuleren. Na enkele jaren van uitzet trekt geslachtsrijpe snoek via een vispassage op eigen gelegenheid elk jaar naar het paaigebied.

\section{Resultaten}

Uit inventarisaties blijkt dat het paaigebied jaarlijks gemiddeld 18.000 snoekjes voortbrengt. Bemonsteringen van de Binnenschelde laten zien dat deze snoekjes goed groeien en aan het einde van het eerste groeiseizoen gemiddeld een lengte bereiken van ruim $30 \mathrm{~cm}$ bereiken. Het snoekpaaigebied is daarmee een succes. Alleen was gedurende de aanleg van het paaigebied de visbiomassa, met name van brasem al sterk toegenomen. Er komt daardoor elk jaar zo veel jonge witvis bij dat snoek niet in staat is om de visstand te reguleren, met als gevolg dat de Binnenschelde een troebel, brasemgedomineerd systeem is. Momenteel wordt daarom onderzocht welke maatregelen genomen kunnen worden om de Binnenschelde weer om te laten slaan naar een helder systeem, waarbij jonge snoek uit het paaigebied wel in staat is om de witvisstand in toom te houden. 


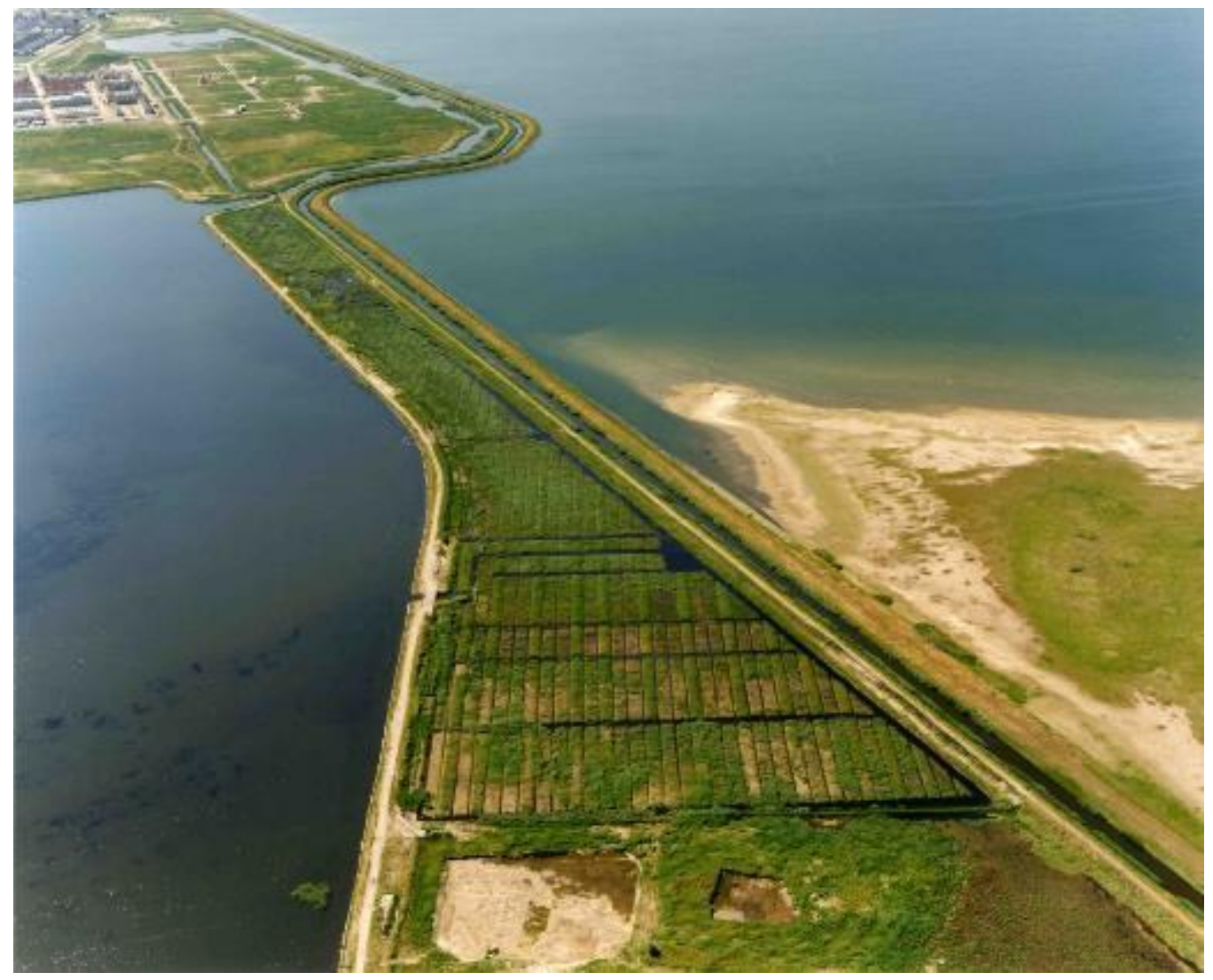

Paaigebied vanuit de lucht

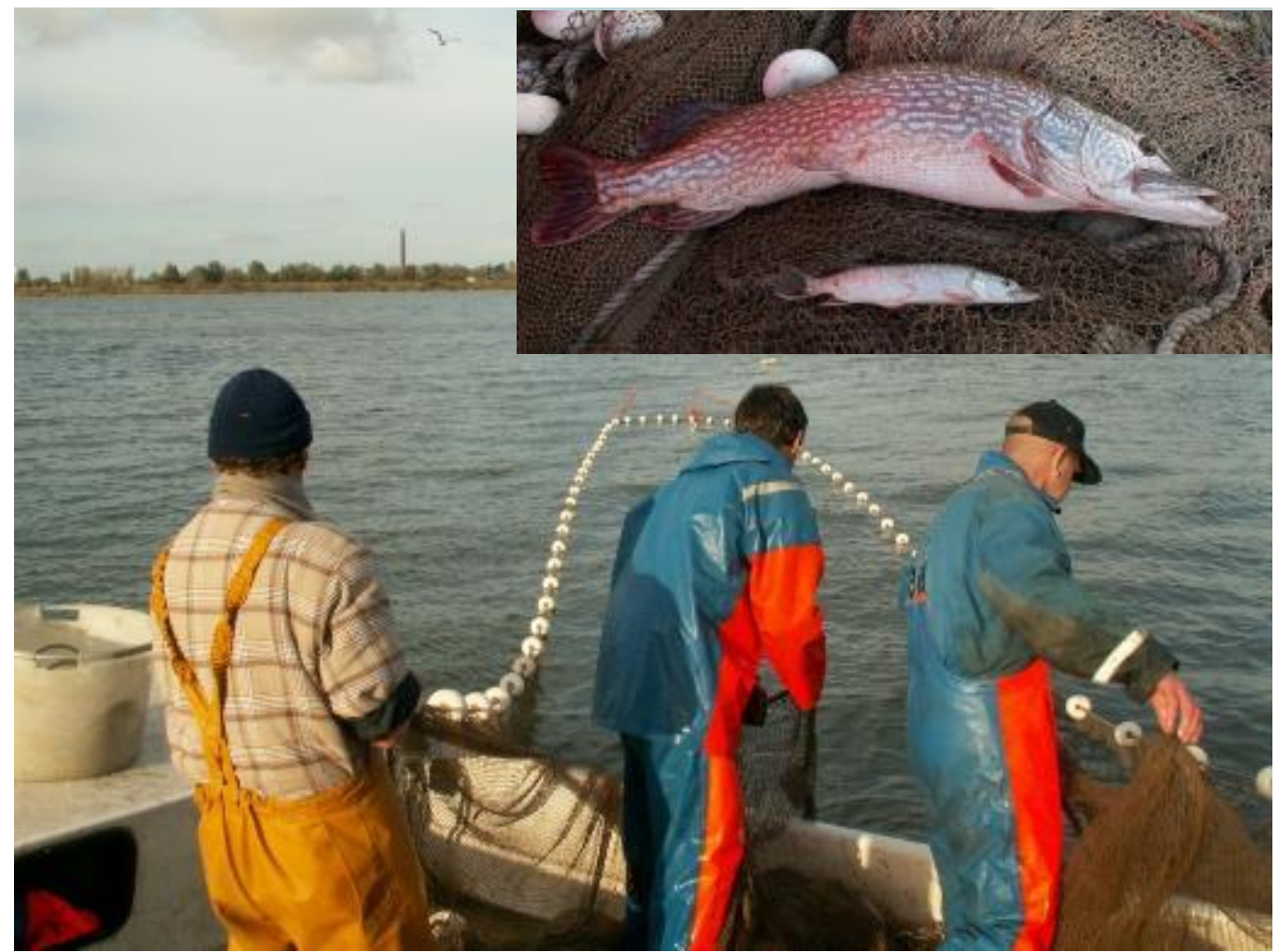

Visstandbemonstering op de Binnenschelde in 2008. Inzet: meerjarige snoek en jonge snoek van paaigebied aan einde van eerste groeiseizoen. 


\title{
Verbetering waterkwaliteit Groote Melanen
}

\section{Setting}

Het betreft een ondiepe plas van 4,8 ha aan de rand van stedelijk gebied (Bergen op Zoom, Halsteren), watertype M11 (kleine ondiepe gebufferde plas).

\section{Doel}

De Groote Melanen heeft een natuurfunctie en wordt gebruikt voor de hengelsport en door wandelaars. Sinds de jaren '90 treden er in de zomer regelmatig blauwalgenbloeien op met gezondheidsrisico's voor mens en dier. Ondergedoken waterplanten ontbraken en de visstand was eenvormig met veel bodemwoelende vis (karper). In sommige winters trad wintervissterfte op. Het doel van de uitgevoerde maatregelen was om het risico op blauwalgenbloeien structureel terug te dringen, het risico op wintervissterfte te verminderen en de helderheid van het water te laten toenemen met groeimogelijkheden voor ondergedoken waterplanten. Dit zou leiden tot een verhoogde natuur- en belevingswaarde.

\section{Streefbeeld}

Sterke vermindering van het risico op blauwalgenbloeien gedurende meerdere jaren waarbij het streven was om de zomergemiddelde totaal-fosfor concentratie $<0,05 \mathrm{mg} \mathrm{P} / \mathrm{l}$ te laten zijn.

\begin{abstract}
Aanpak
Uit een diagnostische watersysteemanalyse bleek dat de oorzaak van de blauwalgenbloeien lag in zowel externe aanvoer van fosfor als in de grote nalevering van fosfor uit de waterbodem. De aanwezigheid van veel bodemwoelende vis bestendigde de troebele toestand zonder waterplanten. De uitgevoerde maatregelen - die in 2015-2016 in nauwe samenwerking tussen waterschap Brabantse Delta en gemeente Bergen op Zoom zijn uitgevoerd - waren gericht op het sterk terugdringen van zowel de externe als interne belasting met fosfor, aanpassing van de visstand en herinrichting van de plas zodat er meer mogelijkheden konden ontstaan voor water- en oeverbegroeiing. De uitgevoerde maatregelen om de externe belasting met fosfor terug te dringen waren de aanleg van een omleiding zodat verontreinigd water om de plas zou worden heengeleid, verminderen van de bladinval door het snoeien en verwijderen van houtige begroeiing op de oevers, en voorlichting aan gebruikers (o.a. hengelsport). Om de interne belasting vanuit de waterbodem terug te dringen is eerst een veld-experiment uitgevoerd waarbij diverse kansrijke opties zijn onderzocht. De bodemwoelende vis is verwijderd, de plas is gebaggerd en de achtergebleven bodem is afgedekt met schoon zand waaraan een fosfaatbindend middel op basis van bentoniet (commercieel beschikbaar als Phoslock $($ ) is toegevoegd. Aan het water is een vloeibaar vlokmiddel (polyaluminiumchloride) toegevoegd om algen en opgeloste fosfaten uit het water te verwijderen. De oevers zijn natuurvriendelijk ingericht en door het terugdringen van de houtige begroeiing kwam er meer licht op de oevers voor oevervegetatie.
\end{abstract}

\section{Resultaten}

$\mathrm{Na}$ de maatregelen zijn in de zomers van 2016 en 2017 geen hoge concentraties blauwalgen meer voorgekomen. Het doorzicht verbeterde sterk en ondergedoken waterplanten hebben zich gevestigd. De zomergemiddelde fosfor concentraties zijn gedaald van $\sim 0,4 \mathrm{mg} \mathrm{P} / \mathrm{l}$ naar waarden $<0,05 \mathrm{mg} \mathrm{P} / \mathrm{I}$. Door goed beheer zal de verbeterde situatie kunnen bestendigen. 

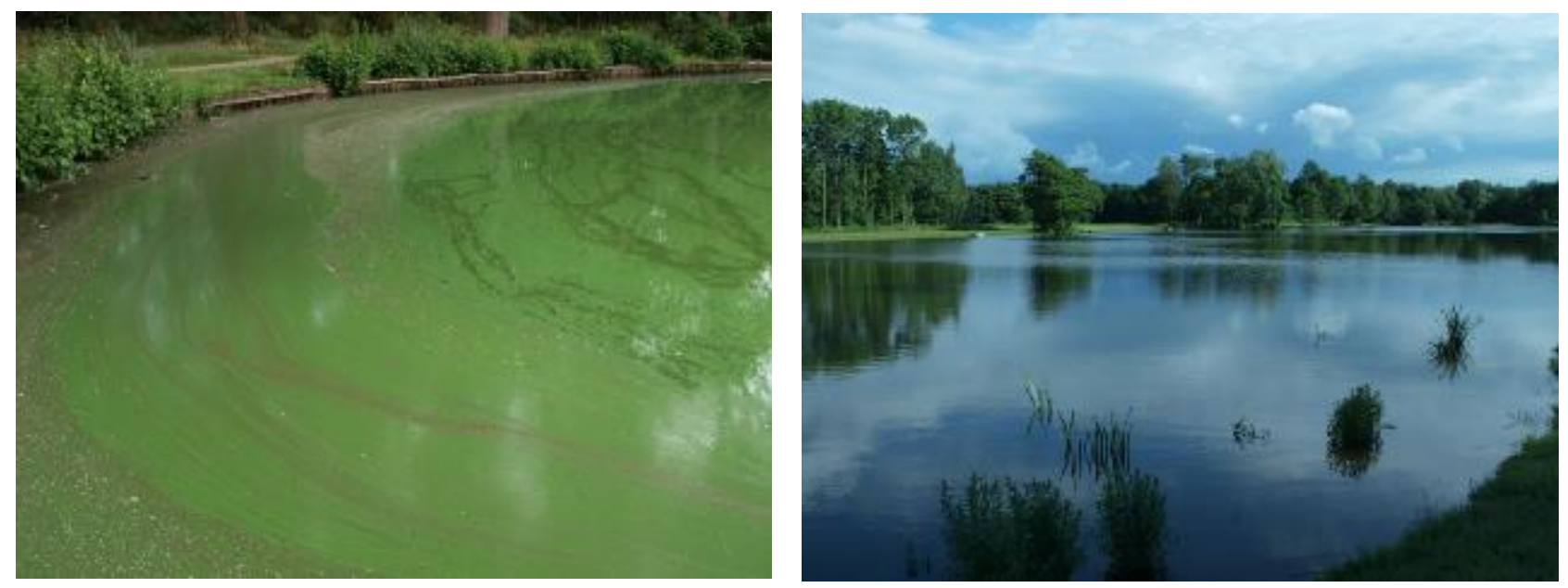

Blauwalgenbloei in de Groote Melanen, voor de maatregelen (13 juli 2010; links) en na de maatregelen (25 juni 2016; rechts).

\section{Verbetering waterkwaliteit zwemplas De Kuil}

\section{Setting}

Het betreft diepe zwemplas van 6,7 ha aan de rand van stedelijk gebied (Breda, Prinsenbeek), watertype M16 (diepe gebufferde meren).

\section{Doel}

Aan De Kuil is een officieel aangewezen zwemwater op basis van de Europese zwemwaterrichtlijn. Sinds begin jaren ' 90 treden er regelmatig blauwalgenbloeien op, die een gezondheidsrisico vormen voor zwemmers. De blauwalgenbloeien resulteerden in waarchuwingen of zwemverboden. Het doel van de uitgevoerde maatregelen was om het risico op blauwalgenbloeien structureel te verminderen en daarmee de zwemwaterkwaliteit gedurende een langere periode (meerdere jaren) te verbeteren.

\section{Streefbeeld}

Sterke vermindering van het risico op blauwalgenbloeien gedurende meerdere jaren.

\section{Aanpak}

Uit een diagnostische watersysteemanalyse bleek dat de oorzaak van de blauwalgenbloeien lag in de grote nalevering van fosfor uit de waterbodem. De externe belasting met fosfor lag in de buurt van de kritische belasting waarboven algenbloeien verwacht kunnen worden. Om de blauwalgenbloeien terug te dringen zijn maatregelen uitgevoerd die gericht waren op het sterk verminderen van de nalevering van fosfor uit de waterbodem. Omdat baggeren financieel onhaalbaar was ( $€ 1.200 .000,-)$ is in mei 2009 een goedkopere innovatieve behandeling toegepast ( $€$ 140.000,-; de behandeling en flankerend onderzoek zijn o.a. mogelijk gemaakt door een bijdrage vanuit het KRW-Innovatieprogramma). De behandeling bestond uit de combinatie van een vloeibaar vlokmiddel (ijzer(III)chloride) en een vast fosfaatbindend middel op basis van bentoniet (commercieel beschikbaar als Phoslock ${ }^{\circledR}$ ). Deze gecombineerde aanpak (Flock \& Lock) verwijderde de blauwalgen uit het water en onderschepte het uit de waterbodem vrijkomen fosfor.

\section{Resultaten}

$\mathrm{Na}$ de behandeling veranderde de pals van een eutrofe toestand in een mesotrofe toestand. Blauwalgenbloeien namen sterk af en vormden gedurende 6 jaar geen probleem meer voor zwemmers. Voor, tijdens en na de behandeling is de waterkwaliteit en bodemnalevering onderzocht. De 
waterkwaliteitsverbetering was direct na de behandeling zichtbaar doordat het doorzicht in enkele dagen toenam van $1,5 \mathrm{~m}$ tot $5 \mathrm{~m}$. Het zomergemiddelde doorzicht over langere periode steeg van 2,31 m (1992-2008) tot 3,12 m (2009-2014). De zomergemiddelde concentraties van totaal-P daalden van 0,05 mg P/l (1992-2008) naar 0,02 mg P/l (2009-2014). De zomergemiddelde concentraties chlorofyl-a daalden van $16 \mu \mathrm{g} / \mathrm{l}$ (1992-2008) naar $6 \mu \mathrm{g} / \mathrm{l}$ (2009-2014). Het door waterplanten bedekte oppervlak verdrievoudigde van 2009 tot 2011. De bodemnalevering van fosfor $(P)$ nam af van 5,2 $\mathrm{mg} \mathrm{P} \mathrm{m}^{-2} \mathrm{~d}^{-1}$ voor de behandeling in 2009 tot $0,4 \mathrm{mg} \mathrm{P} \mathrm{m}^{-2} \mathrm{~d}^{-1}$ na de behandeling in 2010. In de jaren na 2010 steeg de bodemnalevering geleidelijk. Omdat het risico bestond op terugval naar een eutrofe toestand met zomerse blauwalgenoverlast, is in het voorjaar van 2017 een onderhoudsbehandeling met Flock \& Lock uitgevoerd.

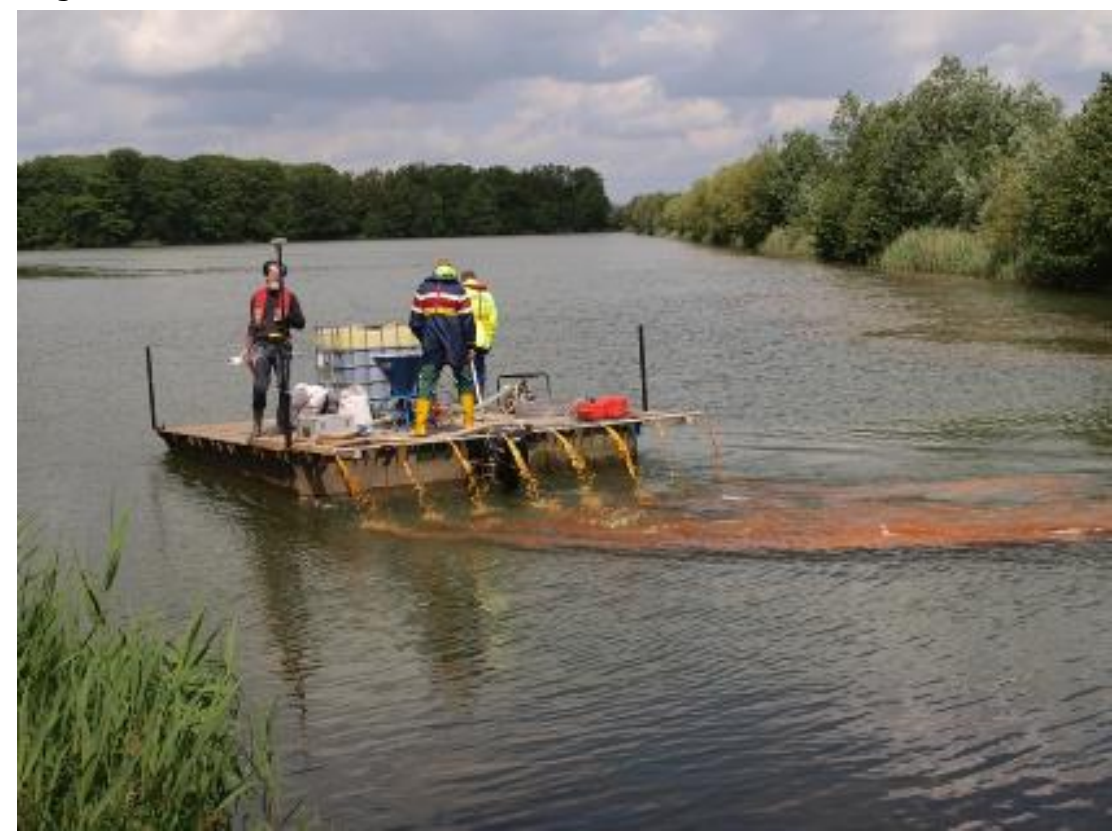

Toediening van het vlokmiddel ijzer(III)chloride (18 mei 2009).

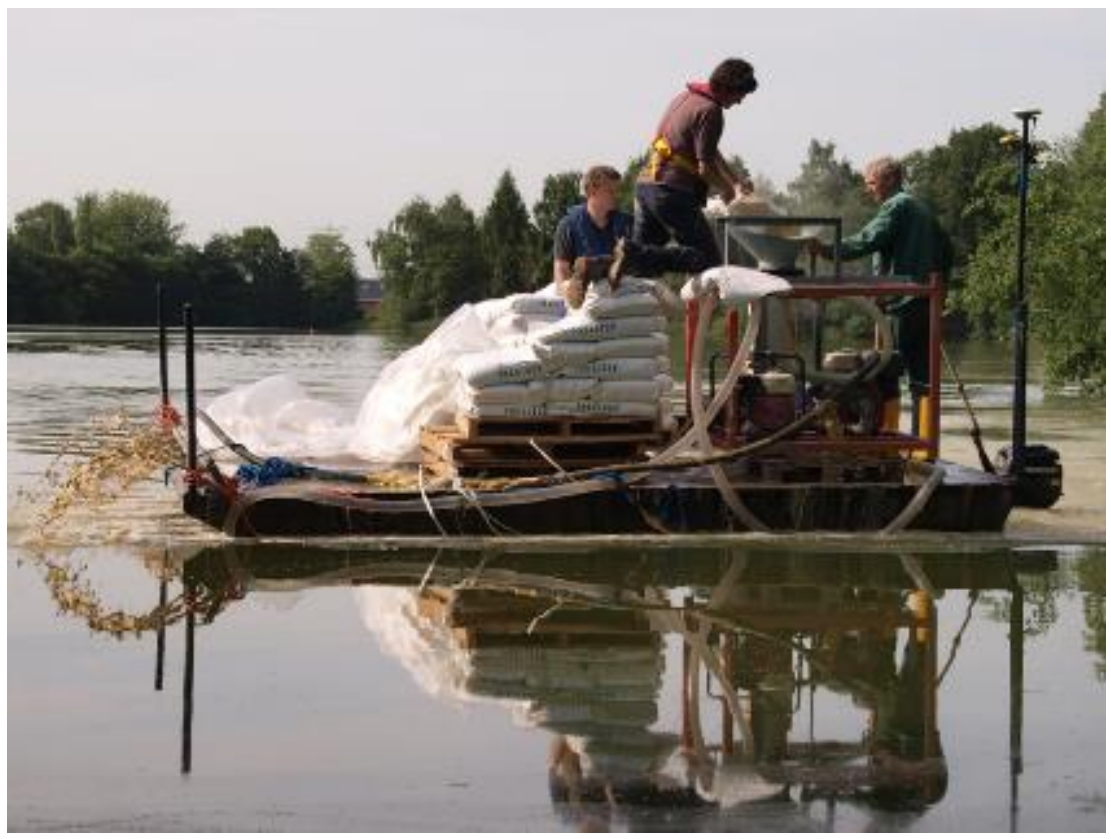

Toediening van het fosforbindend bentoniet (19 mei 2009). 


\section{Bijlage 2 Maatregelenoverzicht overige wateren}

De maatregelen zijn een opsomming van alle maatregelen die de afgelopen decennia in Nederland zijn toegepast (Maatregelwijzer). Echter, hoe, waar en wanneer (combinaties van) maatregelen effectief kunnen worden ingezet, is sterk afhankelijk van de lokale omstandigheden en daarmee in de meeste gevallen waterlichaam-specifiek. Er worden drie schaalniveaus van klein naar groot onderscheiden waar maatregelen kunnen worden ingezet: habitat, traject en beekdal/stroomgebied. In de maatregelenopsomming wordt telkens uitgegaan van een verstoorde uitgangssituatie, bijvoorbeeld een gekanaliseerde genormaliseerde bovenloop in agrarisch gebied zonder bomen erlangs.

\section{Bovenlopen}

\section{Maatregelen op habitatschaal}

1. Laat ingevallen takken, bomen en bladophopingen in de beek liggen.

2. Niet het talud maaien om boomopslag te stimuleren, wanneer bomen niet gewenst taluds eenzijdig alternerend maaien.

3. Onderhoudsfrequentie verlagen van $2-6 x$ per zomerhalfjaar naar $1 x$ (najaar) of zelfs $<1 x$ per jaar (najaar).

4. Wanneer er gemaaid wordt, moeten er plukken vegetatie blijven staan.

5. Maaikorf gebruiken volgens richtlijnen $(10 \mathrm{~cm}$ boven bodem afmaaien vegetatie, niet zoveel materiaal in korf dat spijlopeningen verstoppen).

6. Maaisel niet in beek of op de oever laten liggen, maar uit de oever leggen, afvoeren of op het werkpad/perceel verwerken.

7. Breng een vorm van afrastering aan op betredingsgevoelige plaatsen. Wijs mensen door voorlichting op de kwetsbaarheid van het gebied (bijv. borden aanbrengen).

Maatregelen m.b.t. inrichting beektraject, inclusief de beekoevers

1. Leg bufferstroken aan langs de beek (houtwal met loofbomen of bosstrook, tenminste $4 \mathrm{~m}$ breed). Dit zorgt onder andere voor schaduw, habitat, minder gewasresten in beek, voorkomen inwaaien bestrijdingsmiddelen.

2. Herstel het natuurlijk dwars- en lengteprofiel wanneer een beek genormaliseerd en gereguleerd is. Bomen op de oevers kunnen hierbij helpen doordat hun wortels in de beek groeien.

3. Verwijder stuwen en duikers door bodemsprongen met keien, vistrappen, verlengde cascades o.i.d.

4. Vervang de beschoeiing door oeververdedigende beplanting, wanneer nodig samen met tijdelijke oeververdediging en/of grind/stenen op plaatsen die kwetsbaar zijn voor erosie.

5. Een oeverwalletje tussen beek en het perceel kan oppervlakkige afspoeling voorkomen.

\section{Maatregelen in het beekdal/stroomgebied}

1. Stimuleer stroming door de hoeveelheid wateronttrekking in het inzijggebied te verminderen, bijvoorbeeld door verplaatsen winningen, beperken beregening en drinkenplaatsen vee. 
2. Herstel de sponswerking van het inzijggebied. Verwijder drainagestelsels en/of demp de greppels en sloten. Bevorder de infiltratie van regenwater in de grond, o.a. via gescheiden riolering met regenwatervijvers, rechtstreekse afvoer van daken in de bodem, open bestrating.

3. Sta inundatie toe en leg inundatievlakten aan, hierdoor verdwijnt de stromingsenergie tijdens hoge afvoeren en wordt bijvoorbeeld insnijdingen het wegspoelen van habitat voorkomen.

4. Zet aanliggende landbouwgronden in het beekdal om in natuur, bij voorkeur in bos.

5. Vorm naaldboompercelen in het inzijggebied om naar loofbos.

6. Verbreek de verbindingen met de beek, en scheid hierdoor de landbouwwaterstromen van de natuurwaterstromen.

7. Directe puntlozingen saneren, zoals rioolwateroverstorten, rioolwaterzuiveringsinstallaties, industrieel proceswater, afvalwater van boerderijen. Wanneer aansluiten op de riolering (nog) niet mogelijk is, aanleg septic tanks, evt in combinatie met nazuivering door een helofytenfilter.

8. Ga diffuse lozing van voedingsstoffen tegen vanaf landbouwpercelen door normering, wetgeving en controle.

9. Verminder oppervlakkige afspoeling van sediment vanaf hellend akkerland door ploegvoren dwars op de afstroomrichting maken.

\section{Sloten}

\section{Maatregelen op habitatschaal}

1. Niet de complete watergang maaien, maar eenzijdig maaien, blokken of plukken vegetatie laten staan (ritsbeheer), alleen middenbaan maaien (stroombaanmaaien), langdurig helemaal niet maaien. Er moet wel worden voorkomen dat de watergang gaat verlanden, dit kan weer negatieve effecten hebben.

2. Niet hele complete talud maaien, maar eenzijdig alternerend. Let op negatieve effecten boomopslag (in tegenstelling tot beken is voor sloten beschaduwing en bladval ongunstig)

3. Maaikorf gebruiken volgens richtlijnen $(10 \mathrm{~cm}$ boven bodem afmaaien vegetatie, niet zoveel materiaal in korf dat spijlopeningen verstoppen).

4. Maaisel niet in sloot of op de slootkant laten liggen, maar uit de oever leggen, afvoeren of op het werkpad/perceel verwerken.

5. Onderhoudsfrequentie verlagen van $2-6 x$ per zomerhalfjaar naar $1 x$ (najaar) of zelfs $<1 x$ per jaar (najaar).

6. Baggerfrequentie verlagen, alleen baggeren wanneer noodzakelijk voor waarborging waterafvoer (ecologische optimale frequentie circa om de 8-10 jaar).

8. Wanneer zich een dicht dek kroos of kroosvaren vormt dit aanpakken met gespecialiseerde apparatuur (kroosschuimspaan).

9. Uitrasteren oeverzone om vertrapping vegetatie door vee te vermijden, drinken via weidepomp.

\section{Maatregelen m.b.t. inrichting sloot}

1. Oevervegetatie-ontwikkeling stimuleren via aanleg natuurvriendelijke oevers (NVO's), plas-drasoevers, taludhelling verflauwen (gradiënt nat-droog langer), lichte over-dimensionering watergang.

2. Connectiviteit verhogen tussen sloten via verhogen vispasseerbaarheid stuwen en duikers.

3. Diepe overwinteringsplaatsen voor vissen aanleggen.

4. Bufferstrook of bemestingsvrije zone (tenminste $4 \mathrm{~m}$ ) aanleggen, zodat geen gewasresten in de sloot terecht komen of bestrijdingsmiddelen inwaaien. Vegetatie stimuleren i.v.m. filterfunctie.

5. Oeverwalletje tussen sloot en perceel ter voorkoming van oppervlakkige afspoeling. 


\section{Maatregelen in het watersysteem (polder)}

1. Verblijftijd water verhogen (kwel-gedomineerd) of verlagen (doorspoelen bij hoge nutriëntenlast, verzilting).

2. Inlaat gebiedsvreemd water verlagen door verhoogde waterretentie eigen water in natte perioden, via ophoging waterpeil in sloten zelf of in retentiebassins.

3. Streven naar hydrologische isolatie kwelsloten met goede waterkwaliteit, geschikt voor insecten en watervegetatie maar strijdig met vispasseerbaarheid: gebiedsspecifieke keuzes maken.

4. Bij inlaat gebiedsvreemd water met samenstelling die problemen kan veroorzaken (bijv. te hoog nutriëntengehalte, toxische stoffen) weglengte verlengen zodat meer zuivering door oevervegetatie (helofyten) of absorptie sediment kan optreden.

5. Peilbeheer optimaliseren voor levenscyclus/gedrag doelsoorten (bijv. van omgekeerd naar natuurlijk peil).

6. Op gebieds-/polderschaal gefaseerd maaien in plaats van het hele gebied/polder in een keer, verdeeld over meerdere jaren.

7. Directe puntlozingen saneren, zoals afvalwater van boerderijen.

8. Ga diffuse lozing van voedingsstoffen tegen vanaf landbouwpercelen door normering, wetgeving en controle.

\section{Stadswateren}

\section{Maatregelen op habitatschaal}

1. Bij een lijnvormige watergang niet de complete watergang maaien, maar eenzijdig maaien of alleen middenbaan maaien (stroombaanmaaien), in zowel lijnvormige wateren als vijvers kan worden gekozen om blokken of plukken vegetatie laten staan (ritsbeheer) of langdurig helemaal niet te maaien. Er moet wel worden voorkomen dat het water te sterk gaat verlanden, dit kan weer negatieve effecten hebben.

2. Niet hele complete talud maaien, maar eenzijdig alternerend. Let op negatieve effecten boomopslag (in tegenstelling tot beken is voor stilstaande wateren veel beschaduwing en bladval ongunstig).

3. Maaikorf gebruiken volgens richtlijnen ( $10 \mathrm{~cm}$ boven bodem afmaaien vegetatie, niet zoveel materiaal in korf dat spijlopeningen verstoppen).

4. Maaisel niet op de kant laten liggen, maar uit de oever leggen, afvoeren of ter plekke verwerken.

5. Onderhoudsfrequentie verlagen naar $<1 \times$ per jaar (najaar).

6. Regelmatig snoeien bomen en struiken langs watergang om hoeveelheid invallend blad in water te verminderen.

7. Baggerfrequentie verlagen, alleen baggeren wanneer noodzakelijk voor waarborging waterafvoer of waterkwaliteit.

8. Wanneer zich een dicht dek kroos of kroosvaren vormt dit aanpakken met gespecialiseerde apparatuur (kroosschuimspaan).

9. Zwerfvuil zo snel mogelijk verwijderen.

10. Creëren bewustwording bewoners m.b.t. voeren eenden en vis (geen etensresten in het water).

\section{Maatregelen m.b.t. inrichting waterpartijen}

1. Oevervegetatie-ontwikkeling stimuleren via (deels) verwijderen beschoeiingen, aanleg natuurvriendelijke oevers (NVO's), plas-dras oevers, taludhelling verflauwen (gradiënt nat-droog langer), lichte over-dimensionering watergang. 
2. Connectiviteit verhogen, bijvoorbeeld stuwen en duikers vispasseerbaar maken.

3. Negatieve invloed recreatie (vertrappen vegetatie) oevers voorkomen door delen oever uit te rasteren. Ruimtelijke scheiding functies natuur en recreatie.

4. Bufferstrook ter voorkoming van afspoeling van wegwater met toxicanten of macro-ionen (strooizout), idem hondenuitlaatveldjes langs waterpartijen. Vegetatie stimuleren i.v.m. filterfunctie.

\section{Maatregelen in het watersysteem stadswateren}

1. Verblijftijd water verhogen (kwel-gedomineerde waterpartijen) of verlagen (doorspoelen bij hoge organische belasting) Hiervoor is wel connectiviteit nodig.

2. Gescheiden rioolsysteem voor hemelwater en riool, zie ook hieronder.

3. Verkleinen hoeveelheid verhard oppervlak, stimuleren infiltratie door bijvoorbeeld verharding te vervangen door groen, regentonnen bij huizen, waterdoorlaatbare vormen van verharding toepassen en wadi's aanleggen.

4. Directe puntlozingen (rioolwateroverstorten) saneren. Niet overstorten op stadsvijvers. 